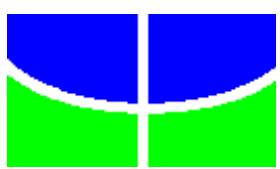 \\ UNIVERSIDADE DE BRASÍLIA \\ FACULDADE DE AGRONOMIA E MEDICINA \\ VETERINÁRIA \\ PROGRAMA DE PÓS-GRADUAÇÃO EM AGRONEGÓCIOS
}

LEYDY EVONNE LOPEZ PALECHOR

\section{ANÁLISE HISTÓRICO-COMPARATIVA DA HELICICULTURA NA COLÔMBIA}

DISSERTAÇÃO DE MESTRADO EM AGRONEGÓCIOS

PUBLICAÇÃO: 127/2016 


\section{LEYDY EVONNE LOPEZ PALECHOR}

\section{ANÁLISE HISTÓRICO-COMPARATIVA DA HELICICULTURA NA COLÔMBIA}

Dissertação apresentada à Banca de Mestrado do Programa de Pós-graduação em Agronegócios, da Faculdade de Agronomia e Medicina Veterinária da Universidade de Brasília (UnB), como requisito parcial para a obtenção do grau de Mestre em Agronegócios.

Orientador: Prof. Dr. Marlon Vinícius Brisola Co-orientadora: Profa. Dra. Elizabeth de S. R. Ibarra 
PALECHOR, L. E. L. Análise histórico - comparativa da helicicultura na Colômbia. 2016. Dissertação. (Mestrado em Agronegócios) - Faculdade de Agronomia e Medicina Veterinária, Universidade de Brasília, Brasília, 2016.

Documento formal, autorizando reprodução desta dissertação de mestrado para empréstimo ou comercialização, exclusivamente para fins acadêmicos, foi passado pelo autor à Universidade de Brasília e acha-se arquivado na Secretaria do Programa. O autor reserva para si os outros direitos autorais, de publicação. Nenhuma parte desta dissertação de mestrado pode ser reproduzida sem a autorização por escrito do autor. Citações são estimuladas, desde que citada a fonte.

\section{FICHA CATALOGRÁFICA}

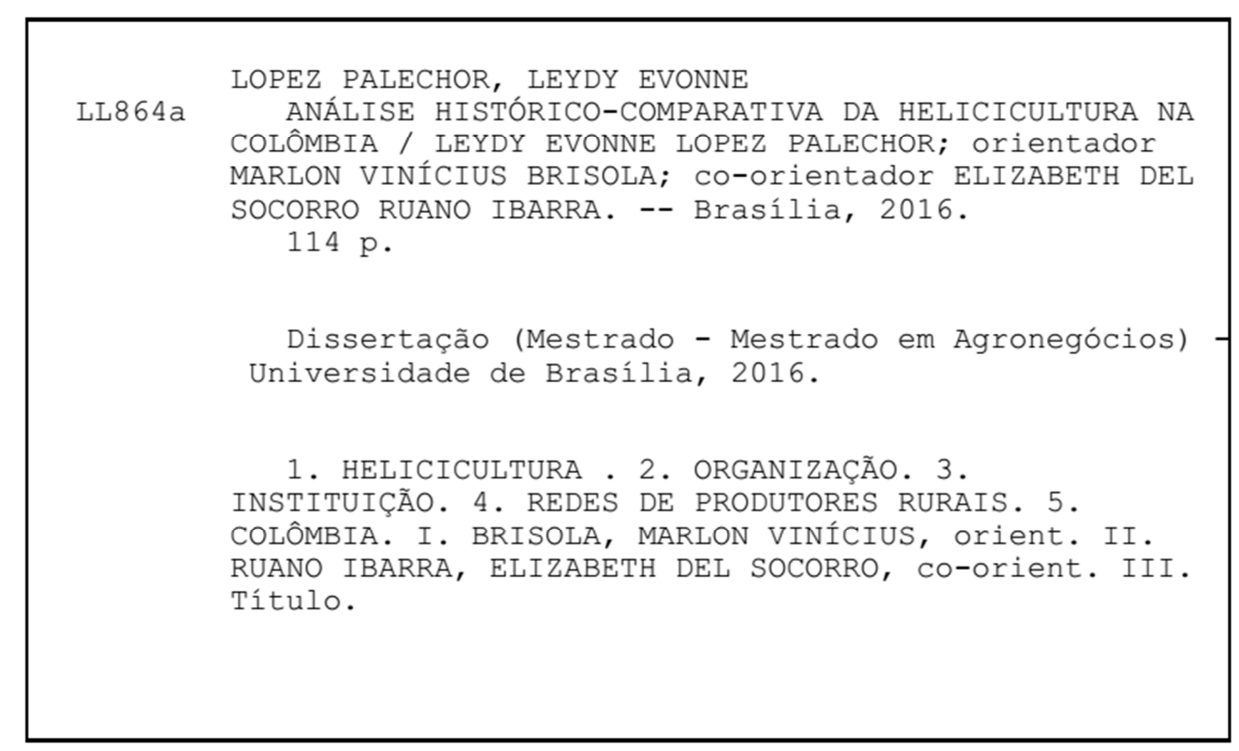




\section{ANÁLISE HISTÓRICO-COMPARATIVA DA HELICICULTURA NA COLOMBIA}

Dissertação apresentada ao curso de Mestrado do Programa de Pós-graduação em Agronegócios da Faculdade de Agronomia e Medicina Veterinária da Universidade de Brasília (UnB), como requisito parcial para a obtenção do grau de Mestre em Agronegócios.

Aprovada pela seguinte Banca Examinadora:

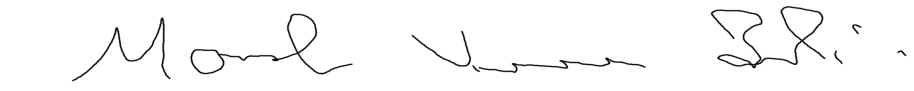

Prof. Dr. Marlon Vinícius Brisola - UnB (ORIENTADOR)
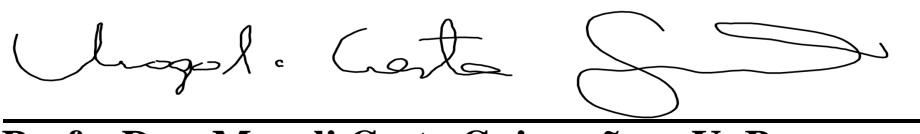

Profa. Dra. Magali Costa Guimarães - UnB

(EXAMINADORA INTERNA)

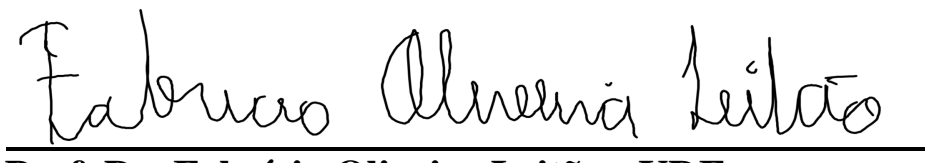

Prof. Dr. Fabrício Oliveira Leitão - UDF

(EXAMINADOR EXTERNO) 
Dedicatória

Aos meus pais Nidia Maria Palechore Nilson Lopez pelo apoio incondicional. Ao теи irmão Erwin Lopez por me incentivar a continuar meus estudos. 


\section{AGRADECIMENTOS}

Primeiramente a Deus por me brindar a fortaleça de cada dia na consecução deste sonho, pela oportunidade de alcançar um logro mais na minha vida.

Aos meus pais Nidia Maria Palechor e Nilson Lopez Santamaria, o motor fundamental da minha vida, com seu apoio, dedicação e amor incondicional faz de mim uma grande pessoa e uma boa profissional. A meu irmão Erwin Lopez que com seu apoio, seus conselhos me guiaram no caminho do sucesso deste anelado sonho. A minha tia Xiomara Lopez por sua entrega, dedicação e ajuda nos momentos difíceis desta etapa. À família Lopez e à família Palechor pelo apoio.

Ao professor Marlon Vinícius Brisola, pela consistente orientação, disponibilidade, apoio e motivação ao longo deste processo de formação. Assim, à professora, Elizabeth S.R Ibarra por ter aportado seus conhecimentos na construção desta dissertação.

Aos professores do Propaga por brindar seus conhecimentos no processo de aprendizagem do Mestrado. À Secretaria Danielle por sua disponibilidade e colaboração os processos administrativos do Propaga.

Agradeço enormemente a Faber Camilo Llanten que sempre estive presente neste processo, com seus conselhos e palavras gratas fortaleceu meu caminhar. Ao meu companheiro Mauricio Merino que com sua paciência e apoio sempre me brindou um sorriso, um abraço nos dias difíceis da minha vida. Aos meus grandes amigos Diego Checa, Juan Sebastian Constain Gomez que desde a distancia sempre me brindaram uma palavra de animo para continuar. Aos meus amigos que tive a oportunidade de conhecer especialmente, Damaris Muñoz, Jaime Alberto Suarez, Christian Gonzalez, Alex Idrobo, Edison Arteaga, Juan Riascos e aos meus colegas principalmente Felipe Morelli e Matteus Martins, pelo companheirismo, amizade e solidariedade, que contribuíram direta ou indiretamente para a elaboração desta dissertação de mestrado.

À Universidade de Brasília, pela oportunidade que me permitiu de continuar meus estudos no Mestrado. À CAPES, pelo suporte financeiro. 
"O homem erudito é um descobridor de fatos que já existem; mas o homem sábio é um criador de valores que não existem e que ele faz existir."

Albert Einstein

"Mestre não é quem sempre ensina, mas quem de repente aprende." 


\section{RESUMO}

Num desenvolvimento de uma atividade econômica são envolvidos muitos fatores que podem ser organizacionais e institucionais e que afetam positiva ou negativamente o seu crescimento. Este é o caso da Helicicultura. Mediante análises destes fatores, se detectam pontos fortes e fracos que influenciam no desenvolvimento ou estagnação da produtividade. $\mathrm{O}$ presente estudo se propôs a analisar organizacional e institucionalmente a cadeia da Helicicultura na Colômbia de forma comparada, em dois períodos de sua existência no País: 2003 e 2013, buscando identificar os fatores determinantes que levaram a uma redução na produção de caracol no País. Para isso, foram consultados documentos públicos de instituições envolvidas nos processos de produção da atividade e realizadas entrevistas com atores importantes de sua cadeia produtiva. Utilizou-se um roteiro de afirmativas com escalas Tipo Likert para avaliar as variáveis internas e externas às unidades de produção que afetam esta atividade helicícola e foi calculada a média das respostas em cada período de tempo correspondente. Em seguida, foi feita a variação do impacto, em porcentagens, entre os períodos de tempo, identificando quais as variáveis que apresentaram maior impacto, e se este foi positivo ou negativo. Os resultados encontrados demostram que a helicicultura não teve um desenvolvimento satisfatório devido a muitos fatores tais como o efeito da legislação regulamentada sobre a atividade no País e seus reflexos na aplicação da tecnologia sobre a atividade, a carência de mão de obra capacitada, a limitação na assistência técnica, à dificuldade dos produtores colombianos em trabalhar coletivamente, entre outros.

Palavras chaves: Helicicultura, Organização, Instituição, Rede de Produtores Rurais, Colômbia. 


\begin{abstract}
A development of an economic activity are involved many factors that can be organizational and institutional and affecting positively or negatively its growth. This is the case of Snail farming. Through analysis of these factors, detect strengths and weaknesses that influence the development or stagnation of productivity. This study aimed to analyze organizational and institutionally the chain Snail farming in comparative form of Colombia in two periods of its existence in the country: in 2003 and 2013 in order to identify the determining factors that led to a reduction in snail production in the country. for this, they were consulted public documents of the institutions involved in the activity of production processes and interviews with key players in the production chain. We used a script statements with Likert scales type to assess the internal and external variables of the production units that affect helicícolas activity and the average of the responses in each corresponding time period was calculated. Then the variation of the impact has been made, in percentages, between time periods, identifying the variables with the greatest impact, and whether it was positive or negative. The results demonstrate that Snail farming has not developed satisfactorily due to many factors such as the effect of regulated legislation on the activity in the country and its impact on the application of technology on the activity, the lack of skilled labor, the limitation on technical assistance, the difficulty of Colombian producers to work collectively, among others.
\end{abstract}

Keywords: Snail farming, Organization, Institution, Network Farmers, Colombia. 


\section{LISTA DE ILUSTRAÇÕES}

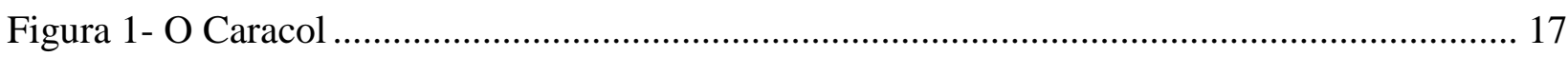



Figura 3- Comparação entre os caracóis Helix aspersa muller ................................................... 19

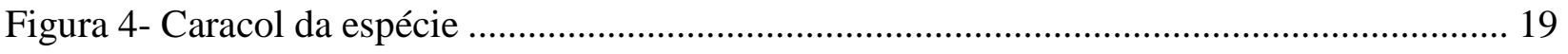

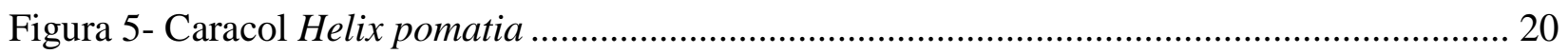

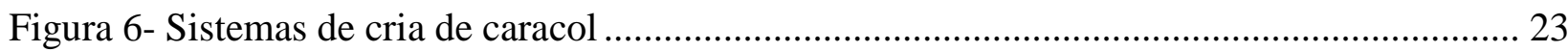

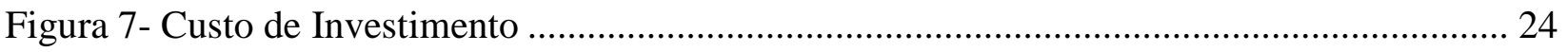

Figura 8- Itens avaliados para investimento na helicicultura ................................................ 24

Figura 9- Comparação de rendimentos em Sistemas de produção na helicicultura ...................... 25

Figura 10- Demanda mundial de caracóis comestíveis terrestres............................................... 27

Figura 11- Projeção do consumo de carne de caracol .............................................................. 28

Figura 12-Exportações dos países autorizados .......................................................................... 29

Figura 13- Comparação de exportações por regiões ................................................................ 30

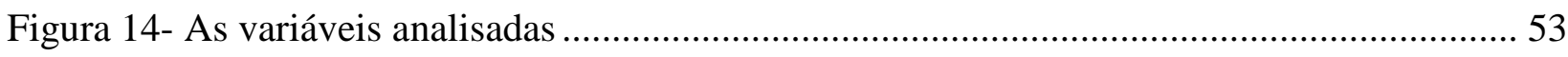




\section{LISTA DE TABELAS}

Tabela 1- Carne de caracol em comparação alimentícia ........................................................ 22

Tabela 2 - Custos de Investimento dos Sistemas (em Dólares)............................................... 23

Tabela 3- Dados avaliados para investimento total na helicicultura .......................................... 24

Tabela 4- Comparação de rendimentos dos sistemas ................................................................. 25

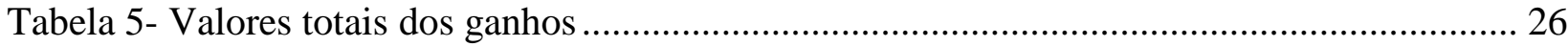

Tabela 6- Volume e valor das exportações de carne de moluscos colombianos .......................... 33

Tabela 7-Resultados da pesquisa: médias e impressões sobre pontuações apresentadas pelos respondentes. 


\section{LISTA DE QUADROS}

Quadro 1- Condições ambientais de cria de caracol ............................................................. 21

Quadro 2- Nutrientes, em 100 gramas, de carne de caracol. .................................................... 21

Quadro 3- Empreendimentos helicícolas na Colômbia ............................................................ 34

Quadro 4- Níveis de análise da Nova teoria Institucional .................................................... 41

Quadro 5. Fontes da pesquisa documental e bibliográfica utilizada .......................................... 49

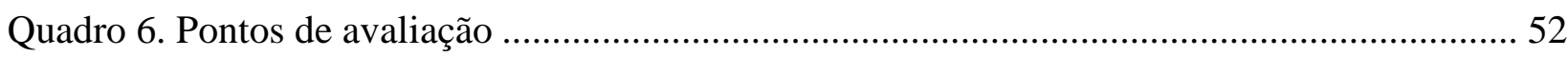

Quadro 7. Relação de especialistas entrevistados ................................................................... 56



Quadro 9- escala de correspondência de comparação .............................................................. 57

Quadro 10- Regulamentação da helicicultura colombiana 1993 - 2010 .................................... 58

Quadro 11. Resumo dos resultados da comparação dos anos ................................................. 87 


\section{SUMÁRIO}

1. INTRODUÇÃO ............................................................................................................................................. 11

1.1 Descrição da problemática.................................................................................................................. 12

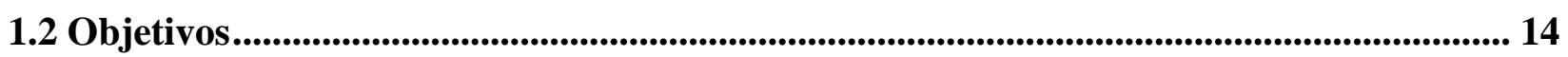

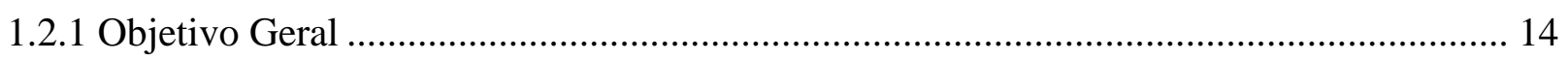

1.2.2 Objetivos Específicos .................................................................................. 14

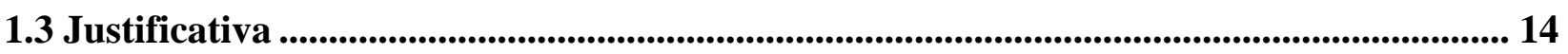

2. QUADRO TEORICO DE REFERENCIA ................................................................................. 17

2.1 Helicicultura e suas espécies .............................................................................................................. 17

2.1.1 Características dos caracóis e de sua produção ………………………………………….... 20

2.1.2 Helicicultura no Mundo.......................................................................................... 26

2.1.3 Helicicultura na America Latina ………………………………………………..... 29

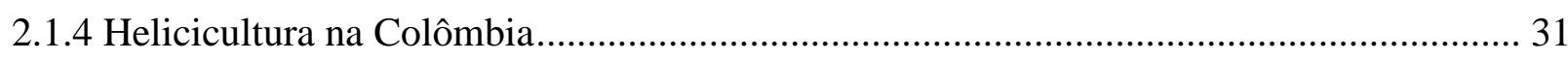

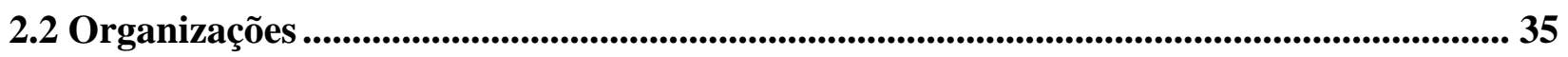

2.2.1 Análise Organizacional............................................................................................. 37

2.3 Instituições............................................................................................................................................... 37

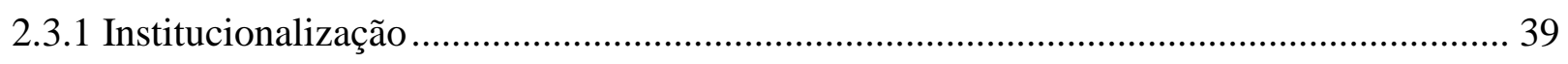

2.4 Organizações e Instituições na Helicicultura na Colômbia ....................................................... 41

2.5 Redes e Ação coletiva ............................................................................................................................ 43

2.5.1 Ação coletiva e redes na Helicicultura colombiana............................................................. 46

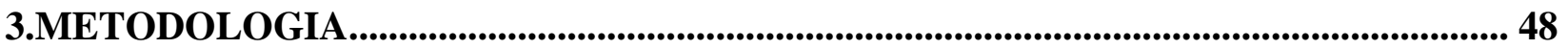

3.1 Instrumentos e procedimentos para a coleta dos dados.............................................................. 48

3.2 Variáveis de pesquisa .................................................................................................... 52

3.2.1 Variáveis do ambiente externo .................................................................................. 53

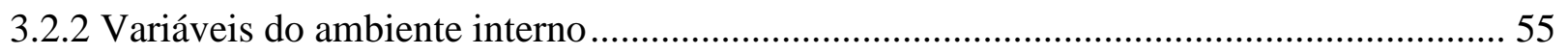




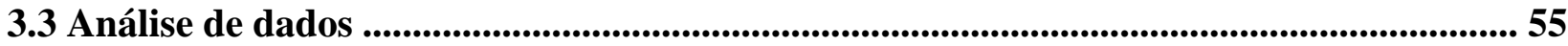

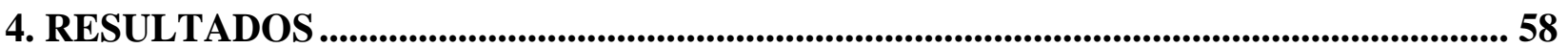

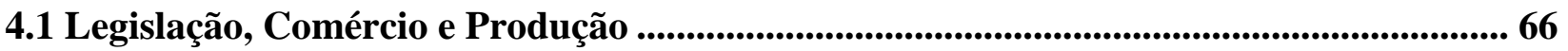

4.2 Estrutura, Gestão e Assistência Técnica .................................................................................. 74

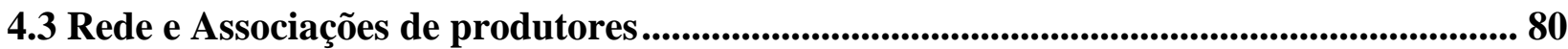



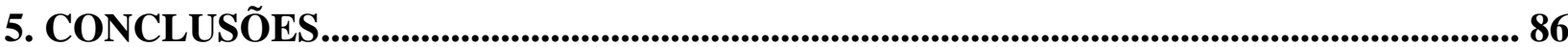

REFERENCIAS BIBLIOGRÁFICAS .......................................................................................... 90

APÊNDICE A- ROTEIRO DE AFIRMATIVAS .............................................................................. 95

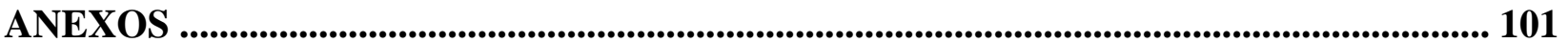




\section{INTRODUÇÃO}

Atualmente, com o fenômeno da globalização, o mundo tornou-se um ambiente mais dinâmico. Isso tem permitido a interdependência entre os países, os acordos comerciais, a troca de valores sociais e culturais, avanços na tecnologia, novos sistemas de informação e, principalmente, a exigência de novos produtos que envolvem a abertura de novos mercados. Esta dinâmica permite que os setores econômicos contribuam com o desenvolvimento de um país ou região. Concomitantemente, são redefinidas as políticas públicas e os sistemas regulatórios que afetam positiva ou negativamente os grupos sociais, urbanos e rurais. Estas transformações são tão profundas para o meio rural, principalmente para as organizações rurais, podendo chegar ao ponto de promover o fim de uma atividade rural. Por outro lado, pode ocorrer uma reestruturação agrária que permita uma reconfiguração do espaço rural, onde os atores tenham mais oportunidades de exploração da terra, mais direitos de propriedade, mais associatividade, o que ajuda a melhorar a qualidade dos cultivos, a qualidade de vida e a incursão de novos nichos de mercado. Por conseguinte, novos mercados incentivam as pequenas e médias empresas a criar novos produtos tentando suprir as necessidades dos consumidores insatisfeitos, mediante processos produtivos inovadores, adoção de novas técnicas, processos e procedimentos mais consolidados, o que contribui para o crescimento econômico das mesmas. Especificamente no setor agropecuário, por exemplo, empresas optam pela produção de alimentos orgânicos livres de substâncias química prejudiciais à saúde dos consumidores.

Em se tratando de negócios inovadores, surge a helicicultura (criação comercialização de carne de caracol) como empreendimento de um produto que atende a modo de alimentação saudável. Esta oferece muitos benefícios aos consumidores. Trata-se d uma carne com menos gordura, mais proteínas, mais saudável e de fácil digestão.

Para os produtores, trata-se de uma atividade agrícola rentável, com uma grande demanda, principalmente nos países europeus. Assim por requerer uma tecnologia específica para a produção, os empreendedores devem traçar um plano de negócios bem estruturado, se adequando a um cultivo de consumo próprio. Para tanto, muitas vezes, é recomendado o trabalho de maneira conjunta, onde o produtor se associa com outros produtores para obter maiores benefícios em seus cultivos principalmente, se se pretende alcançar mercados internacionais.

Já na Colômbia, campo deste estudo, esta atividade é desenvolvida desde o ano 1972, mediante um estudo de factibilidade da cria de caracol na Savana de Bogotá, realizado pela 
empresa Proexport e produtores franceses, o que determinou que esta atividade pudesse ser viável o seu desenvolvimento neste país, logrando-se obter benefícios econômicos para os atores da cadeia produtiva e um grande desenvolvimento comercial. Atualmente, alguns departamentos ${ }^{1}$ colombianos desenvolvem esta atividade. Segundo Rodriguez et al., (2011), no ano 2006, quando o Governo colombiano regulamentou a produção do caracol por meio da Lei 1011, houve um forte interesse de produtores rurais em cultivar este produto. Isso gerou a formação de associações de produtores, entre elas, a principal Asociación Colombiana de Helicicultores (Asocohelix), que chegou a ter até 60 helicicultores associados, segundo documento enviado pelo diretor da Associação o Sr. Javier E. Zambrano, em 2015. Com o passar do tempo, porém, os helicicultores foram se desligando da Associação e deixando de cultivar o caracol. Atualmente, esta associação conta com apenas 13 produtores associados ativos, nos departamentos de Cundinamarca, Antioquia, Boyacá e Caldas.

Frente a essa realidade, a situação da helicicultura na Colômbia hoje é peculiar. A redução dos associados e a baixa produção dos caracóis renegaram a oportunidade de que a Colômbia viesse a pertencer ao grupo dos países da América Latina, aptos a exportar carne de caracol, como é o caso da Argentina, Chile e Peru (RODRIGUEZ et al., 2011).

Com este estudo, procura-se perceber quais foram os fatores determinantes que levaram à queda da produção de caracol na Colômbia, mediante uma análise organizacional e institucional desta atividade, e das redes de helicicultores no País. Considerando a Asocohelix, a principal associação de helicicultores colombianos, busca-se analisar os aspectos referentes aos helicicultores, suas relações de associatividade e suas relações com as instituições que regulamentam esta atividade. Utilizou-se, para tanto, uma análise históricocomparativa do contexto produtivo de caracol num lapso de tempo de 10 anos (2003-2013). A análise foi feita mediante a coleta de dados primários e secundários.

\subsection{Descrição da problemática}

Sabe-se que o desenvolvimento de uma nova atividade, como a helicicultura, implica em sincronismo entre a capacidade dos atores produtivos, o mercado e as instituições formal e informalmente estabelecidas no âmbito local e nacional. Na América do Sul, atualmente, há três países diretamente envolvidos no comércio internacional de caracóis: Chile, Peru e Argentina. O Brasil produz apenas para atender ao mercado interno (RODRIGUEZ et al., 2011).

\footnotetext{
${ }^{1} \mathrm{Na}$ Colômbia os departamentos e municípios constituem a divisão político-administrativa. O Departamento tem
} semelhança com o "Estado" da estrutura política brasileira. 
Considerando a análise neste estudo, o desenvolvimento da helicicultura (criação de caracol e produção de produtos derivados a partir deles) parece ser uma alternativa interessante de desenvolvimento de novos mercados: demanda pouco investimento e apresenta baixo custo de manutenção e comercialização - isso devido ao fato que os caracóis têm uma alta fecundidade e são adaptáveis a diferenças climáticas que o país oferece e os custos com a alimentação dos mesmos, é bem baixo. Trata-se de uma atividade econômica rentável, com elevada demanda dos seus produtos a nível mundial, especialmente pelos países europeus. Além disso, na Colômbia a helicicultura passou a ser uma atividade legalmente estabelecida recentemente. Embora haja poucas regiões que desenvolvem essa atividade econômica hoje, a produção, segundo Monje e Gutierrez (2007),já esteve espalhada por Departamentos como Antioquia, Boyacá, Caldas, Casanare, Cundinamarca, Meta, Quindío, Risaralda, Santander, Tolima e Valle del Cauca y Cauca, com cerca de 10.800 helicicultores ativos. Porém atualmente, esta produção está concentrada nos Departamentos de Cundinamarca, Antioquia, Boyaca e Caldas.

Logo nos anos 2006 e 2007, após regulamentação, a atividade alcançou seu auge na produção. Muitas pessoas e empresas familiares se associaram, buscando fazer crescer a atividade e alcançarem maiores benefícios com ela. Foi criada uma federação e associações de helicicultores. Entre elas, a principal, Asocohelix, procurou consolidar uma rede de produtores que ajudariam na aquisição de novos conhecimentos, avanços no campo da produção, serviços de assistência técnica, tecnologia, recursos financeiros, entre outros aspectos que envolvem a cadeia de produção. Mas, anos mais tarde, veio o decréscimo da atividade: os produtores deixaram a associação, eles trabalharam isoladamente, o volume de produção diminuiu e, hoje em dia, é pouca a produção, devido a fatores desconhecidos.

Para o conhecimento sobre o avanço e o recuo da produção de caracóis na Colômbia, faz-se necessário entender as relações entre os principais atores participantes de sua cadeia produtiva, alguns organizados em redes, e destes com os atores dos contextos organizacional e institucional. Sabe-se que as estratégias de um setor produtivo são diretamente dependentes destas relações e instituições. Conhecer os aspectos organizacionais e institucionais que envolvem as redes de helicicultores, sua evolução, as caraterísticas dos agentes envolvidos, os produtos da ação coletiva, a cultura e os avanços tecnológicos permite conhecer as razões de sua trajetória na Colômbia e o que impediu o setor de se posicionar para tornar o País um player exportador deste produto. 
A situação histórica descrita acima, e reconhecendo que são poucas as redes de helicicultores atualmente estabelecidas na Colômbia, buscou-se entender as razões de sua trajetória e responder, por meio da comparação temporal, a seguinte questão-problema:

Quais foram os principais fatores organizacionais e institucionais que influenciaram na variação do volume de caracol produzido na Colômbia no intervalo de 10 anos (2003-2013)?

\subsection{Objetivos}

\subsubsection{Objetivo Geral}

Analisar histórica e comparativamente os aspectos organizacionais e institucionais da helicicultura na Colômbia, identificando fatores que influenciaram na variação da produção, no intervalo de 10 anos (2003- 2013).

\subsubsection{Objetivos Específicos}

1. Levantar e descrever os contextos organizacional e institucional que afetam a helicicultura na Colômbia;

2. Identificar os elementos desses contextos num lapso de tempo de10 anos (2003 e 2013);

3. Comparar os achados identificados no intervalo de tempo referente à helicicultura colombiana;

4. Identificar os principais elementos que culminaram na variação da produção de caracóis de terra no país ao longo dos últimos anos.

\subsection{Justificativa}

O aporte econômico do setor agrícola é muito importante para a economia de um país ou região, uma vez que permite contribuir substancialmente para o desenvolvimento econômico do mesmo. Num país como Colômbia, que tem uma grande variedade de recursos naturais (mais de um milhão de hectares de florestas; vários quilômetros de costa com os oceanos Pacífico e Atlântico; três regiões naturais, com praticamente todas as zonas climáticas; três vales e cinco grandes bacias hidrográficas), diferentes culturas podem ser 
acomodadas, tais como o café, a cana de açúcar, a batata, o milho, a mandioca e outros produtos, fazendo com que a economia aumente sua participação no PIB.

A população rural do país, na sua maioria é composta por pequenos e médios agricultores que possuem pequenas extensões de terras, algumas delas exploradas atualmente para cultivo, embora alguns produtores ainda conservem parte de suas terras ociosas, buscando uma atividade agrícola de retorno em curto prazo, com garantia de boa rentabilidade, provedora de novos métodos de trabalho e novas formas de explorar os recursos disponíveis, desenvolvendo atividades de cunho familiar. Além de atender às necessidades de novos mercados, a helicicultura passa a ser uma alternativa interessante.

Com alto teor de proteína e baixo teor de gordura, segundo Proaño; Lema e Valverde (2006, p.39) a carne de caracol está expandindo seu mercado mundial. O principal consumidor, atualmente, é a Comunidade Europeia, mas em países como o Japão e os Estados Unidos ela também está gradualmente se espalhando. A França, que é o maior consumidor mundial desse molusco, tem uma demanda anual de 50 mil toneladas, representadas num consumo de $1 \mathrm{~kg} /$ pessoa por ano. Deste montante, importa aproximadamente 20\%. Soma-se a esta demanda o consumo da Itália, Espanha, Alemanha, Suíça e de outros países da Comunidade Europeia, bem como Japão e Estados Unidos, cujas produções não são suficientes para atender às necessidades crescentes. Logo, a helicicultura mostra-se como uma atividade comercial bastante atrativa.

A expansão da helicicultura representa uma grande oportunidade para os países do hemisfério sul, especialmente a Colômbia, já que quando as nações do norte estão em período de inverno e os caracóis estão inativos, no sul eles estão no período de reprodução e de engorda, o que torna benéfica a produção e exportação para muitos produtores, pois, permite a oferta de volumes inexistentes nas diferentes latitudes. Considerando os aspectos levantados sobre o comércio e a oportunidade de produção de caracóis na América do Sul, torna-se importante realizar uma análise histórico-comparativa sobre a produção do crustáceo no referido país, identificando porque razão a atividade teve sua trajetória alterada ao longo dos últimos anos.

Para tanto, elegeu-se, para este estudo, a investigação sobre análise organizacional e institucional das estruturas de produção que envolve a atividade neste país. O estudo comparativo da evolução no intervalo de dez anos, sobre as características e exigências organizacionais e institucionais dos produtores e da região, favorece o entendimento da questão de pesquisa. 
Outra justificativa para o estudo está na avaliação de novos mercados e novos produtos que possam contribuir para que outras regiões ou países desenvolvam esta atividade, o que trará benefícios às pessoas que vivem no meio rural, uma vez que é mais uma alternativa de exploração da terra. A helicicultura é uma atividade pouco explorada, pouco conhecida, mas brinda grandes oportunidades ao setor agrário, não só para a Colômbia, mas também para outros países como o Brasil.

Justifica-se também sua importância para a academia, garantindo que o estudo possa abordar tema e método atual e de grande interesse, permitindo contribuir para o desenvolvimento e aplicação dos conhecimentos adquiridos nas aulas e nas demais atividades da pós-graduação em Agronegócios. Por ser estudante estrangeira afiançar, os conhecimentos como pesquisadores e deixar um trabalho de mestrado como precedente para futuras pesquisas, isso contribui para o programa de mestrado em Agronegócios da Universidade de Brasília na sua constante busca do crescimento acadêmico e internacionalização. 


\section{QUADRO TEORICO DE REFERÊNCIA}

$\mathrm{Na}$ seguinte sessão se apresentam as definições e conceitos de alguns autores que envolvem os temas de pesquisa, neste caso trata-se de conhecimentos da Helicicultura e suas espécies, condições do cultivo, conceitos de organizações e instituições, redes e ação coletiva. Estes conceitos são a base do desenvolvimento da pesquisa.

\subsection{Helicicultura e suas espécies}

A helicicultura é uma palavra de origem latina, que vem da composição "Helix" e "cultura". Helix, pelo nome do gênero atribuído ao caracol, devido a sua concha na forma helicoidal; e cultura, devido ao verbo latino "cultivare" que significa cultivar. Assim a "Helicicultura" representa a cria em ciclo biológico completo de caracóis comestíveis. (HINOJOSA, 2012 p. 33). Assim para este autor a helicicultura é uma atividade agrícola, que envolve uma nova espécie animal como o caracol, desenvolvida pelo homem para consumo humano com fins comerciais.

Os caracóis são moluscos da terra que pertencem à classe Gasteropode(palavra procedente dos termos gregos "gaster" que significa "barriga" e "podos" (que significa "pé"), já que tem o aparato motor debaixo da barriga. Sua principal característica é por apresentar corpo assimétrico (Figura 1), com a cabeça bem diferenciada do resto do corpo. Tem concha em forma helicoidal bem desenvolvida, que protege seu corpo suave e viscoso e, finalmente, possui antenas telescópicas. São hermafroditas insuficientes, ou seja, possuem órgãos genitais femininos e masculinos, mas não podem se auto-fertilizar. Ou seja, para que a fertilização ocorra dois indivíduos são necessários para a cópula (ARIETTI, 2010 p.11).

Figura 1- O Caracol

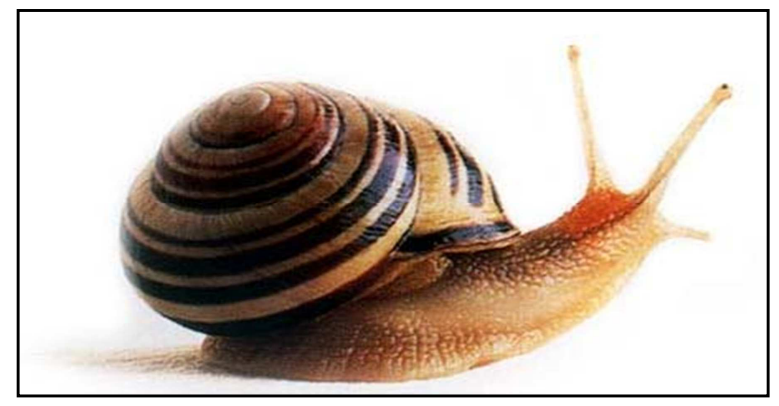

Fonte: Arietti (2010)

$\mathrm{Na}$ Europa Ocidental, são conhecidas, pelo menos, vinte tipos de caracóis para o consumo humano, mas nem todos têm o mesmo valor comercial e diferem nas condições para 
serem exportados. Entre as variedades mais cultivadas estão a Helix aspersa e a Helix pomatia, devido a sua maior capacidade de adaptabilidade aos climas e ao seu rápido crescimento(MONJE; GUTIERREZ, 2007).

Helix aspersa: trata-se da variedade mais comum encontrada na natureza. Esta espécie de caracol possui duas subespécies: a Muller, mais conhecida como Petit-cinza e a Máxima, ou Gros-cinza. Estas duas subespécies têm características similares, mas suas diferenças derivam do tamanho de cada uma.

Segundo Monje e Gutierrez (2007), a subespécie Helix aspersa muller é mais conhecida no mercado interno e é a mais comercializada a nível mundial. É um caracol de pequeno tamanho cujo peso aproximado é de 6 a 18 gramas, normalmente suas medidas são entre 20 e40 mm de altura e $25 \mathrm{~mm}$ de largura. Tem uma forma oval, de cor marrom, com bandas escuras e pequenas antenas (Figura 2). Deposita uma média de 100 ovos, os quais são incubados no período de 15 a 20 dias; isto acontece entre 2 a 4 vezes por ano. O caracol vive até cinco anos. Esta espécie é adaptável aos diferentes tipos de clima e chega a reproduzir-se em até os 1.000 metros de altitude. É a espécie mais representativa do patrimônio helicícola na Europa (OSPINA; MORENO, 2007 p. 14).

Figura 2- Caracol da Espécie

Helix aspersa muller

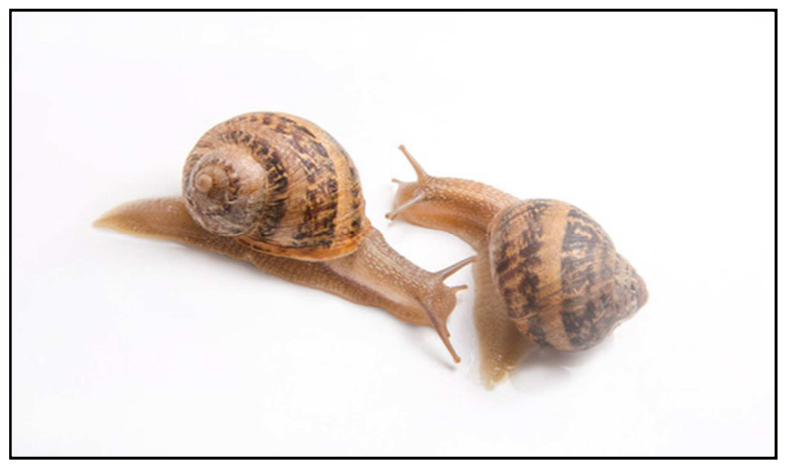

Fonte: Hinojosa (2012)

A subespécie Helix aspersa máxima é similar ao Muller, porém com um tamanho maior, cujo peso pode variar entre 20 e 30 gramas e possuir uma concha de 45 a $48 \mathrm{~mm}$ (Figura 3). Deposita de 90 até 200 ovos (Figura 4). A variedade Máxima é aceitável no mercado, pois é fácil de produzir nas regiões de clima frio e temperado (OSPINA; MORENO, 2007 p. 14). 
Figura 3- Comparação entre os caracóis Helix aspersa Mullere Melix áspera máxima



Fonte: Monje e Gutierrez (2007)

Figura 4- Caracol da espécie

Helix aspersa máxima com ovos



Fonte: Monje e Gutierrez (2007)

Outra variedade comercial mais cultivada é a Helix pomatia, também chamada Vignaiola Branca ou Gros-Blanc (como é conhecida na França) ou ainda, Escargot Borgonha. Na natureza, é encontrada exclusivamente em regiões em que não há influência do mar e seus ventos, razão pela qual não é encontrado facilmente (HINOJOSA, 2012 p. 42).

Seu peso varia entre 18 e 20 gramas, com medidas medias entre30 e $50 \mathrm{~mm}$ de comprimento, 30 e $50 \mathrm{~mm}$ de largura e $50 \mathrm{~mm}$ de altura. Deposita, em média, 60 ovos, e possui um período de incubação de 20 a 30 dias (Figura 5) (MONJE; GUTIERREZ, 2007 p. 19).

Esta espécie possui várias alterações morfológicas, das quais existe uma grande variedade em toda a Itália e em algumas regiões dos Apeninos. Tem sido utilizada em centros de incubação. Hoje é representante de uma helicicultura menos consistente, pois demanda mais tempo para crescer, embora sua carne seja considerada de melhor qualidade (HINOJOSA, 2012 p.43). 
Figura 5- Caracol Helixpomatia

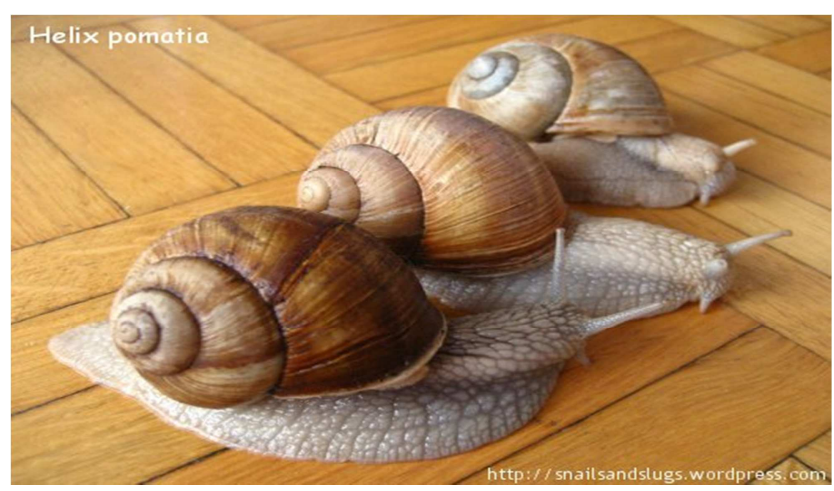

Fonte: Monje e Gutierrez (2007)

\subsubsection{Características dos caracóis e de sua produção}

Os caracóis são moluscos de hábitos noturnos, sempre procuram sombra para fugir da luz. Em sua produção, eles não podem encontrar obstáculos que afetam sua sobrevivência. No seu habitat, se encontrarem problemas, tentarão fugir, o que implica no principal problema da criação: eles sempre procuram liberdade. Os caracóis hibernam quando as temperaturas são muito baixas: inferior a $10^{\circ} \mathrm{C}$ (Quadro 1), se guardando em uma concha, envolvidos por uma membrana (epigrama) e permanecendo com suas próprias reservas até o tempo melhorar. Podem morrer se encontram totalmente isolados (LAGOS, 2004).

A melhor etapa da reprodução do caracol está em suas primeiras semanas como adulto. Depois de quatro ciclos de fecundação, este perde sua capacidade reprodutiva. Sua alimentação é basicamente vegetal e dependem de um alimento concentrado a base de proteínas, celulose, cálcio e vitaminas. Sua respiração exige movimentos de inspiração e espiração. Além da respiração pulmonar, ele tem respiração cutânea, o que proporciona grande resistência aos fenômenos de hipóxia (falta de oxigênio). A excreção é fundamentalmente através de seu único rim e pelo intestino. Além disso, os caracóis podem fecundar duas vezes por ano, uma vez na primavera e outra no outono. Mas se sua alimentação é abundante, segundo os parâmetros apresentados no Quadro 1, sua fecundação pode ser de 3 ou até 4 vezes por ano (MONJE E GUITIERREZ, 2007). 
Quadro 1- Condições ambientais de cria de caracol

\begin{tabular}{|c|c|}
\hline \multirow{2}{*}{ Humidade ambiental sugerida } & $\begin{array}{c}\text { Diurna: } 75-80 \% \\
\text { Noturna: } 85-90 \% \text { (não maior } 95 \% \text { ) }\end{array}$ \\
\hline & Noturna: $85 \%$ - 90\% não maior $95 \%$ \\
\hline \multirow[t]{2}{*}{ Temperatura ótima sugerida } & $\begin{array}{c}\text { Diurna: } 20-22^{\circ} \mathrm{C} \text { (não maior } 25^{\circ} \\
\text { C) } \\
\text { Noturna: } 16-18^{\circ} \mathrm{C}\end{array}$ \\
\hline & Noturna: $16-18^{\circ} \mathrm{C}$ \\
\hline Temperatura de hibernação & Baixo $6^{\circ} \mathrm{C}$ \\
\hline \multirow{2}{*}{ Fotoperíodo } & $\begin{array}{c}18 \text { horas luz } \\
6 \text { horas escuro } \\
\end{array}$ \\
\hline & 6 horas escuridão \\
\hline
\end{tabular}

Fonte: Lagos (2004, p.18)

O valor nutricional da carne de caracol (Quadro 2) representa uma fonte importante de nutrientes. Contém nove dos 10 aminoácidos necessários ao corpo humano na dieta.

Quadro 2- Nutrientes, em 100 gramas, de carne de caracol.

\begin{tabular}{|l|c|}
\hline \multicolumn{1}{|c|}{ Componentes } & Quantidades \\
\hline Calorias & 76 quilo calorias \\
\hline Glicídios & $2 \%$ \\
\hline Proteínas & $15 \%$ \\
\hline Vitamina C & $15 \mathrm{mg}$ \\
\hline Iodo & $0,006 \mathrm{mg}$ \\
\hline Enxofre & $140 \mathrm{mg}$ \\
\hline Água & $82 \%$ \\
\hline Lipídios & $0,80 \%$ \\
\hline Cálcio & $170 \mathrm{mg}$ \\
\hline Ferro & $3,5 \mathrm{mg}$ \\
\hline Magnésio & $250 \mathrm{mg}$ \\
\hline Zinco & $2,2 \mathrm{mg}$ \\
\hline
\end{tabular}

Fonte: Ospina e Moreno (2007, p. 20)

Assim, autores como Monje e Gutierrez (2007) destacam as vantagens da carne de caracol em comparação com as demais: não tem colesterol, baixo teor de gorduras e calorias e possui grande quantidade de água, fato que aporta um valor nutricional mais elevado, conforme apresenta a Tabela 1. Mais mesmo assim constitui uma das comidas 'pesadas', devido ao fato de que sua carne é elástica e de difícil digestão pelos sucos gástricos. Como sugestão, não se pode ingerir continuamente, pois, pode causar problemas na saúde. 
Tabela 1- Carne de caracol em comparação alimentícia

Com outros tipos de carne

\begin{tabular}{ccccc}
\hline Alimento & Água & Proteína & Gorduras & Calorias \\
\hline \hline Carne & 62.8 & 18.8 & 15.4 & 214 \\
Frango & 68.7 & 19.1 & 11 & 175 \\
Ovo & 73.9 & 13 & 11.1 & 156 \\
Peixe & 81.5 & 15.9 & 2.6 & 82 \\
Caracol & 84.9 & 13.4 & 1.7 & 67 \\
\hline
\end{tabular}

Fonte: Pereyra et. al (2003, p. 131)

Deste modo, para os helicicultores, conhecendo os aspectos gerais da helicicultura, tais como a fisiologia do caracol, as condições de vivência, os valores nutricionais, entre outros, é importante que eles possam continuar aplicando os devidos cuidados com estes animais, para assim obter uma carne de qualidade, apta para consumo humano. Entre as condições requeridas para uma adequada produção estão: sementes de boa qualidade, mão de obra adequada, alimentação saudável, uma boa eleição do sistema de cria, o que implica em uma adequada capacitação para os helicicultores e, principalmente, uma boa assistência técnica.

Entre os sistemas de cria para os caracóis, basicamente pode se utilizar três, dependendo do lugar, das condições climáticas, do espaço físico disponível ou das possibilidades econômicas (custos de investimento para desenvolver esta atividade) disponíveis. Segundo dados apresentados por Proaño; Lema e Valverde (2006), os sistemas de produção são: Sistema Aberto ou Extensivo, Sistema Fechado ou Intensivo e Sistema Misto (Figura 6).

Os autores definem Sistema Aberto ou Extensivo é realizado em grandes campos, fechados por redes e protegidos do ar, mantendo longe dos inimigos. Dispõe-se de arvores, plantas, evitando as plantas daninhas. Estas servem de alimento e refúgio dos caracóis, razão pela qual não precisa muita manutenção, sanidade e alimentação, requer menor investimento e mão de obra. A desvantagem deste Sistema vem do tipo de alimentação, pois depende da busca deste pelo animal. Portanto, é mais lenta a engorda e a primeira produção ocorre perto dos dois anos, implicando em menor rendimento por hectare e as estimações de produtividade são mais incertas.

Por outro lado, Proaño; Lema e Valverde (2006) definem Sistema Intensivo ou Fechado é mediante processos controlados, são recintos especiais, com temperatura e humidade controladas, em mesas verticalmente localizadas. Os controles sanitários e 
alimentícios são fortes e estritos, para reduzir o risco às doenças. Mediante este Sistema obtêm-se altos rendimentos, mas seu investimento é mais alto, principalmente com relação à infraestrutura e mão de obra. E por último, o Sistema Misto implica na combinação dos sistemas anteriormente descritos, já que a aplicação do Sistema Intensivo envolve os processos de reprodução, desova e a primeira fase de cria, aproximadamente em oito meses de vida, e o Sistema Extensivo é utilizado para a engorda (4 meses).

A vantagem do Sistema Misto é que durante as primeiras fases de desenvolvimento, os caracóis não estão expostos aos predadores e às mudanças de umidade e temperatura. É mais econômica que o sistema intensivo devido às dimensões do recinto e a infraestrutura serem menores (PROAÑO; LEMA; VALVERDE, 2006).

Figura 6- Sistemas de cria de caracol

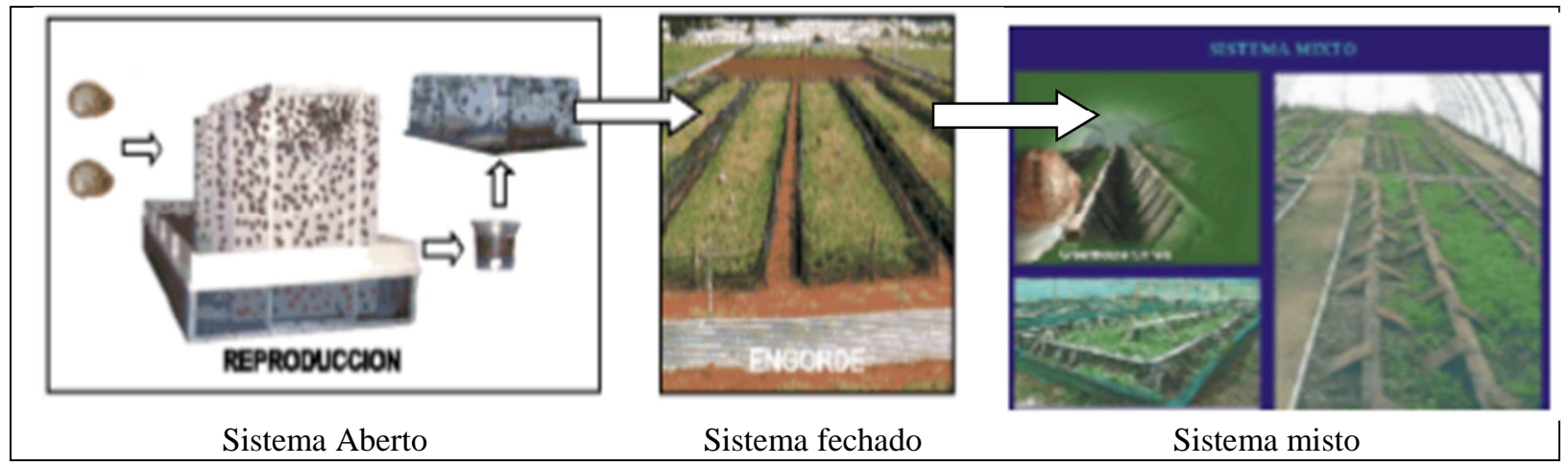

Fonte: Jimenez (2007, p. 15)

Depois de analisar as vantagens e desvantagens dos sistemas, é preciso conhecer os custos dos investimentos que envolvem cada um dos sistemas. Estes dados são apresentados por Proaño; Lema e Valverde (2006) na Tabela 2. E A Figura 7 expõe, comparativamente, os custos de investimento dos três sistemas.

Tabela 2- Custos de Investimento dos Sistemas (em Dólares)

\begin{tabular}{lcrr}
\hline & $\begin{array}{c}\text { Sistema } \\
\text { Extensivo }\end{array}$ & $\begin{array}{c}\text { Sistema } \\
\text { Intensivo }\end{array}$ & $\begin{array}{r}\text { Sistema } \\
\text { Misto }\end{array}$ \\
\hline \hline Investimento Total & $33.648,79$ & $25.835,77$ & $26.024,84$ \\
Custos Fixos Mensais & $1.870,24$ & $2.036,43$ & $1.845,24$ \\
\hline
\end{tabular}

Fonte: Proaño; Lema; Valverde (2006) 
Figura 7- Custo de Investimento

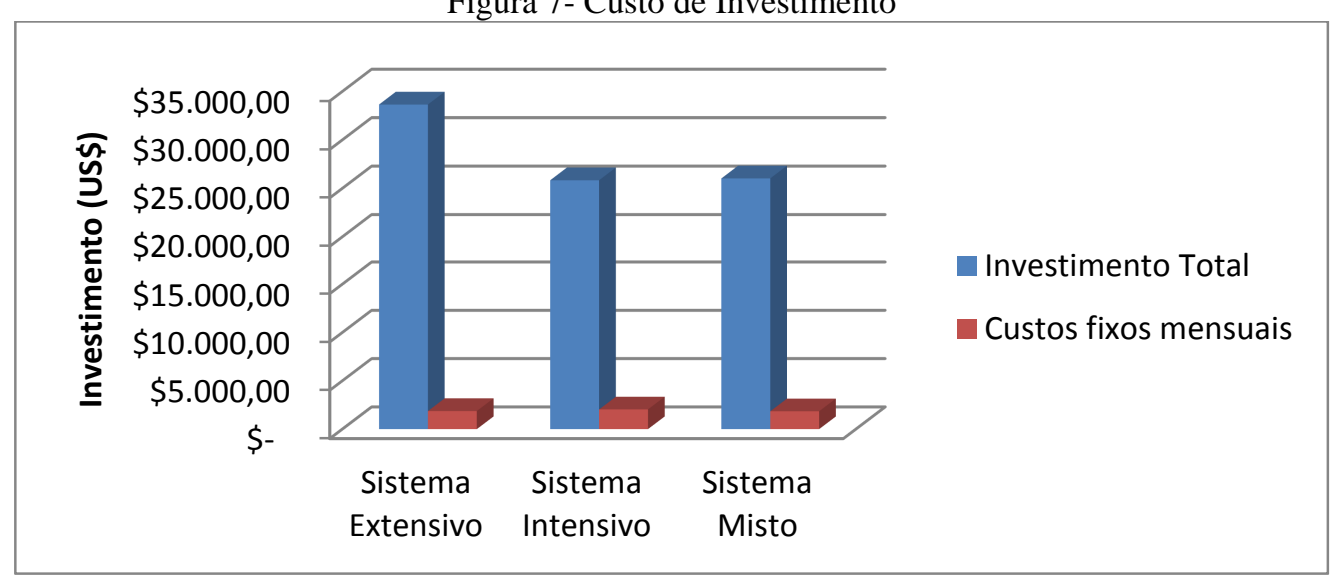

Fonte: Proaño; Lema; Valverde (2006)

Para obter o investimento inicial, o autor avalia três principais estruturas, tais como: a preparação da terra, a infraestrutura e a área administrativa, como apresentam a Tabela 3 e a

Figura 8.

Tabela 3- Dados avaliados para investimento total na helicicultura

\begin{tabular}{lrrr}
\hline & Sistema Extensivo & $\begin{array}{c}\text { Sistema } \\
\text { Intensivo }\end{array}$ & Sistema Misto \\
\hline \hline Preparação do terreno & 212,29 & $6.035,66$ & 577,34 \\
Infraestrutura & $19.876,50$ & $11.100,11$ & $11.887,50$ \\
Oficinas & $13.560,00$ & $8.700,00$ & $13.560,00$ \\
\hline & Fonte: Proaño; Lema; Valverde (2006)
\end{tabular}

Figura 8- Itens avaliados para investimento na helicicultura

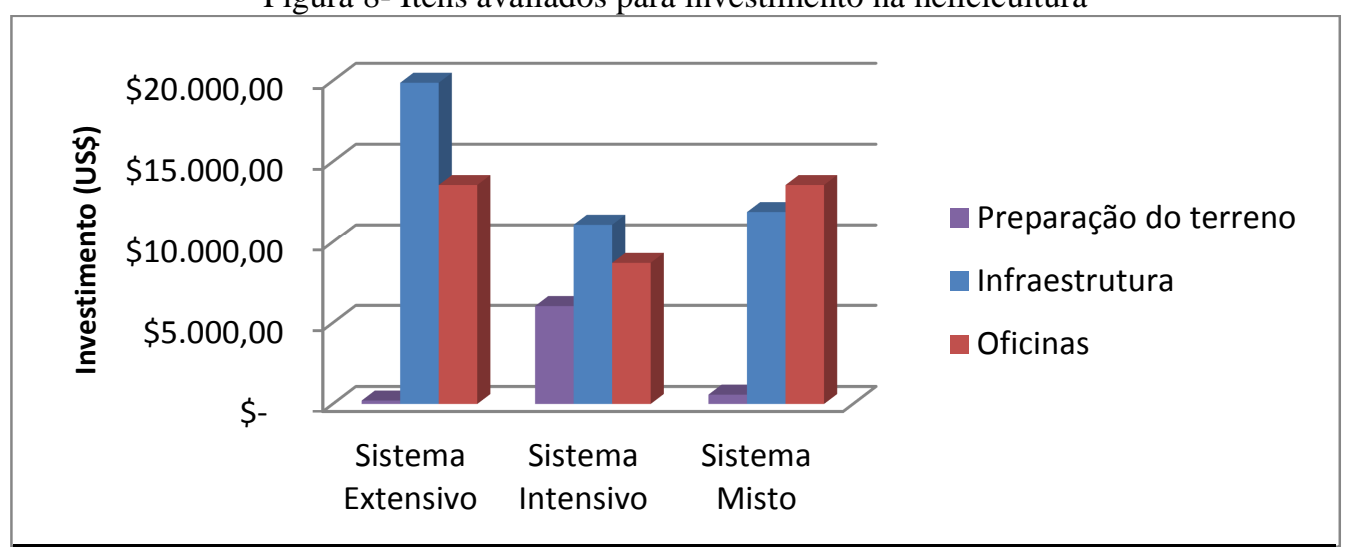

Fonte: Proaño; Lema; Valverde (2006). 
Mediante análise dos custos de investimentos e os custos fixos pode-se observar que o sistema mais favorável para os helicicultores é o sistema misto, o qual requer de um valor mais alto de investimento do que o sistema intensivo, mas que os benefícios estão nos custos fixos mensais, o que permitirá ao helicicultor obter uma renta mais alta. A preparação da terra e a infraestrutura requerem itens básicos que podem ser adquiridos pelos produtores. A principal vantagem é que, para a primeira fase se faz um considerável investimento, que poderá ser recuperado na fase de engorda, pois não necessita muita reparação dos campos.

Conforme exposto, para uma produção em média de $1.500 \mathrm{~kg}$ de carne de caracol, segundo Proaño; Lema; Valverde (2006), para os sistemas de cria, é preciso diferentes áreas para obter diferentes rendimentos. Por exemplo, para uma área de $858 \mathrm{~m}^{2}$ no Sistema Intensivo, pode-se obter um rendimento de $1,7 \mathrm{~kg} / \mathrm{m}^{2}$, uma quantidade maior que com os outros Sistemas, e mais benéfica para a renda dos produtores (Tabela 4; Figura 9).

Tabela 4- Comparação de rendimentos dos sistemas

\begin{tabular}{lrrr}
\hline & Sistema Extensivo & Sistema Intensivo & Sistema Misto \\
\hline \hline Área Total $\left(\mathrm{m}^{2}\right)$ & 4.884 & 858 & 1.142 \\
Produção mensal $(\mathrm{Kg})$ & 1.500 & 1.500 & 1.500 \\
& & & 1,31348 \\
Rendimento em media $\mathrm{kg} / \mathrm{m}^{2}$ & 0,307125307 & 1,748251748 & 5114 \\
\hline
\end{tabular}

Fonte: Proaño; Lema; Valverde (2006)

Figura 9- Comparação de rendimentos em Sistemas de produção na helicicultura



Fonte: Proaño; Lema; Valverde (2006) 
Os dados apresentados na Tabela 4 permite observar que o Sistema Intensivo tem maior rendimento em $\mathrm{kg} / \mathrm{m}^{2}$, mas seu investimento é muito mais alto o que afeta o produtor, enquanto que o Sistema Misto oferece um rendimento de $1,3 \mathrm{~kg} / \mathrm{m}^{2}$ com baixos custos. Os resultados financeiros apresentados na Tabela 5 mostra que o Sistema Misto apresenta uma mais alta taxa interna de retorno $(62,37 \%)$, isto é, em média, os rendimentos futuros planejados para a quantidade de investimentos correspondente aos US \$26.024,84 anualmente (PROAÑO; LEMA; VALVERDE, 2006).

Tabela 5- Valores totais dos ganhos

\begin{tabular}{lccc}
\hline & & & \multicolumn{2}{c}{ Taxa Interna de Retorno } \\
Sistema & Investimento $(\$$ US) & Valor Anual Líquido(\$ US) & (\%) \\
\hline \hline Extensivo & 33,78 & 38,75 & 42,02 \\
Intensivo & 26,41 & 25,06 & 56,3 \\
Misto & 25,40 & 28,47 & 62,37 \\
\hline \multicolumn{4}{r}{}
\end{tabular}

Pode-se concluir que, para se obter um produto de qualidade, apto para consumo humano, os produtores devem conhecer os aspectos gerais do que vai ser cultivado, neste caso os caracóis.

\subsubsection{Helicicultura no Mundo}

O consumo de caracol ocorre desde a antiguidade. Fujimoto (2006) diz que desde o homem paleolítico já se utilizava o caracol como alimento para sobrevivência. Isto é demonstrado pelos achados arqueológicos em cavernas. Como atividade agrícola, o aproveitamento de sua carne e a comercialização teve origem na Grécia, no período de domínio do Império Romano. Já o primeiro parque helicícola surge em uma cidade da Toscana, chamada Tarquemia, perto de Roma, onde os caracóis eram engordados com vinho e farelo até alcançarem grande tamanho para serem levados à mesa. Plinio foi a primeira pessoa a escrever sobre os caracóis e fez referência a Fulvius Lippinus como o primeiro especialista nesses gastrópodes. Até no século XVIII os caracóis representaram alimento somente para os nobres, já que a igreja considerava sua carne impura (VIEIRA, 1984).

Foi no século XIX, quando os Franceses sofreram de uma grande escassez de alimentos devido à Revolução Francesa, que as pessoas iniciaram a procura por carnes de outros animais e a desenvolver pratos que até então pareciam pouco prováveis; que o caracol 
representou fonte para vários deles e posteriormente, o consumo foi se expandindo pela Europa (OSPINA; MORENO, 2007).

No início do século XX, foi aumentando a demanda por caracóis e, consequentemente, o seu valor econômico. Por esta razão, alguns pioneiros fizeram as primeiras tentativas de realizar a sua criação em ciclo completo, em grandes parques abertos, o que resultou em altos índices de mortalidade dos animais. Este fato levou os criadores a estudarem maneiras de protegê-los melhor de seus predadores, controlarem os exemplares que se tornariam reprodutores, e assim, garantir a manutenção da criação e estabelecer condições ambientais ideais para a sua sobrevivência. Atualmente, muitos são os países onde se desenvolvem importantes estudos sobre novas técnicas de criação, tipos de alimentação e doenças dos caracóis. A França, a Alemanha, a Itália e a Espanha aparecem como os países destaques nas experimentações sobre a biologia e a criação racional destes moluscos, objetivando assegurar um resultado econômico positivo para os criadores e garantindo o mercado do consumo interno. No entanto, apesar das muitas pesquisas que são efetuadas em diversos países, há ainda muitos problemas para serem resolvidos na criação em cativeiro, em ciclo completo (RODRIGUES, 1991).

A expansão da helicicultura é uma realidade. Fato devido à grande demanda, principalmente na época do outono e para as festividades de final de ano. De acordo com Sastre (2006), o consumo anual estimado para dez anos (1994 a 2005) foi de 60.000 toneladas na França, 35.000 para Espanha, 32.000 para a Itália. Segundo Proaño; Lema e Valverde (2006), dados estatísticos do Instituto de Helicicultura da Itália sobre a comercialização do caracol estimam para algo próximo de 30 mil toneladas anuais o comércio atualmente no mundo (Figura 10), sendo os principais mercados: Europa (86\%), Ásia (12\%) e América do Norte (2\%), mostrando uma demanda crescente. Acredita-se que a demanda nos próximos 20 anos aumentará em 1,5 milhões de toneladas (Figura 11).

Figura 10- Demanda mundial de caracóis comestíveis terrestres



Fonte: Fujimoto (2006) 
Figura 11- Projeção do consumo de carne de caracol pelos principais países importadores da União Europeia

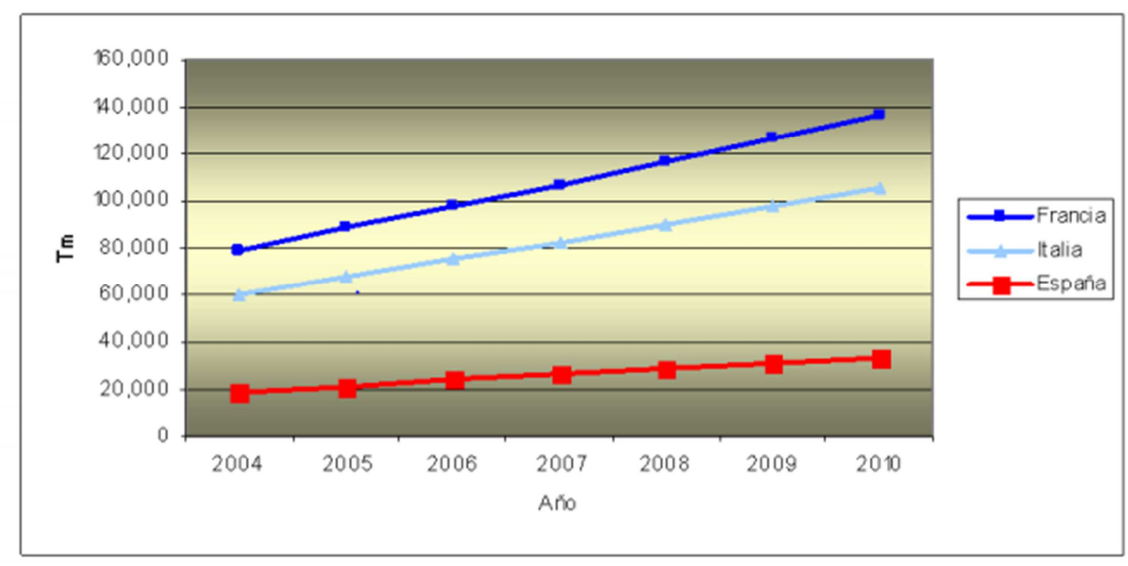

Fonte: Proaño et. al (2006)

A França é o país com bases estáveis para a Helicicultura; dispõe de boa investigação e desenvolvimento de alta tecnologia para o cultivo. Neste país é utilizado o Sistema Fechado com ou sem climatização e se difunde uma tecnologia avançada, visando alcançar mercados de escala na transformação agroalimentar. $\mathrm{Na}$ Itália se utiliza o sistema de cria de ciclo biológico completo. São mais de 6.600 helicicultores ocupando 7.500 hectares para cultivos, cobrindo somente $35 \%$ do consumo interno. Já na Espanha, se comercializam todas as espécies de caracol, exceto a Borgonha. As empresas se especializaram em processos de congelamento por meio de gases e da produção de pré-cozidos com o propósito de implementar novas técnicas para exportação.(NIÑO; TORRES, 2013)

Niño e Torres (2013) asseguram que a cotização no preço dos caracóis entre 2004 e 2013permitiu um aumento de 8 a10\% anualmente. Este fato ocorreu devido ao rápido crescimento da população consumidora do produto e ao baixo nível de produção mundial. Além do mais, a França, o principal consumidor, tem sua produção insuficiente para abastecer o mercado, por causa do uso descontrolado de agrotóxicos e químicos em seus cultivos, o que leva a morte dos moluscos.

Mediante tal situação, pode-se observar que o mercado helicícula tem grande expectativa para o setor agrícola em vários países, tais como Marrocos, China, Indonésia, Turquia entre outros, especialmente para os países da América Latina, onde se considera ter as condições ótimas para seu cultivo; além disso, a vantagem de se ter produção o ano todo em função das condições climáticas. 


\subsubsection{Helicicultura na América Latina}

Na América Latina, o caracol foi introduzido pelos espanhois e italianos por volta do ano 1850, especificamente no México e na Argentina - ano em que o consumo e a comercialização de sua carne aumentaram em Borgonha, e devido ao novo transporte ferroviário que ajudou no acesso a longas distâncias, foi possível manter os moluscos frescos (CASTILLO; CASTILLO, 2002).

Na América Latina, o caracol é encontrado em ambiente silvestre, principalmente nos jardins das casas. O cultivo é algo ainda muito pouco expressivo. Trata-se de uma oportunidade de negócio para estes países. Conforme argumenta Arietti (2012), representa uma oportunidade por ser uma produção de contra estação, ou seja, quando os países do hemisfério norte estão em inverno e os caracóis estão inativos (pois não suportam baixas temperaturas), os países do hemisfério sul estão com as produções em fase de reprodução e engorda. A ampliação da produção para exportação na América do Sul pode trazer muitos benefícios, especialmente econômicos, pois permite oferecer volumes inexistentes aos países consumidores por um preço interessante aos países ofertantes. Esse período de inatividade compreende os meses de novembro a abril. Atualmente Argentina, Chile e Peru são os países autorizados pela Comunidade Europeia, segundo decisão $N^{\circ}$ 96/166/CE, para exportar a variedade Helix aspersa. Por sua vez, o Brasil só produz para o seu mercado interno.

De acordo com Proaño; Lema e Valverde (2006), os países que exportam maior volume de caracóis são Argentina e Peru, seguidos pelo Chile. Entretanto, essa atividade nestes países, não ultrapassa 100 toneladas anuais (Figura 12).

Figura 12-Exportações dos países autorizados anos 1999-2003

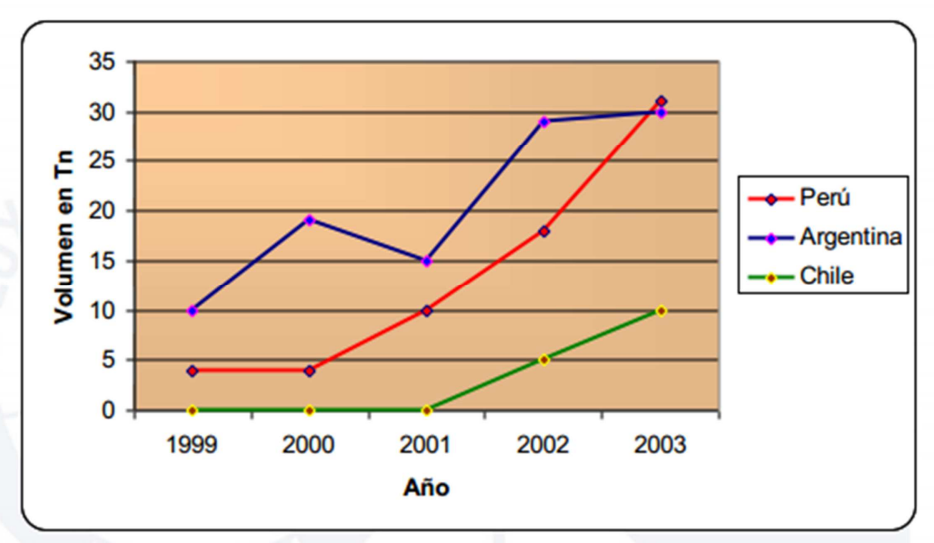

Fonte: Proaño; Lema e Valverde (2006) 
O Chile iniciou a exportação de caracóis para Espanha no ano 2002 e mantém sua produção graças ao apoio das instituições governamentais e, principalmente, devido ao acordo econômico com a União Europeia, de onde obtém grandes benefícios, tais como melhores preços nas transações em comparação com Argentina e Peru. Sua produção é reconhecida pela excelência do produto oferecido, estando na vanguarda do ranking mundial. A Argentina exporta para Espanha desde o ano de 1994. Seu volume de mercado interno é aproximadamente de $400 \mathrm{~kg}$ por ano; e tem apresentado dificuldades em atender as suas remessas para a Europa, que são de aproximadamente 15 toneladas anuais. Por outro lado conforme, Salinas (2006), o Peru exportou para a Espanha entre 1998 e 2004 o montante de 98 toneladas, uma média de 14 toneladas por ano. A partir de 2004, o volume exportado reduziu devido a irregularidades encontradas na mão de obra utilizada e redução da qualidade do produto. Entre os demais países da América Latina, Colômbia, Equador, México e Uruguai são considerados pequenos exportadores.

A Figura 13 apresenta os volumes exportados pelos países da América Latina em comparação com os países europeus e africanos para o ano 2003. A maioria das exportações para a Espanha foi a partir Marrocos, com uma porcentagem de 75\%; Portugal responde com a produção de $24 \%$ da exportação para os demais países consumidores da Europa; e o restante exportado (1\% apenas) é oriundo da América do Sul (PROANO et al., 2006). Margens aproximadas a estas parece serem mantidas até os dias atuais. (HINOJOSA, 2012)

Figura 13- Comparação de exportações por regiões

no ano 2003

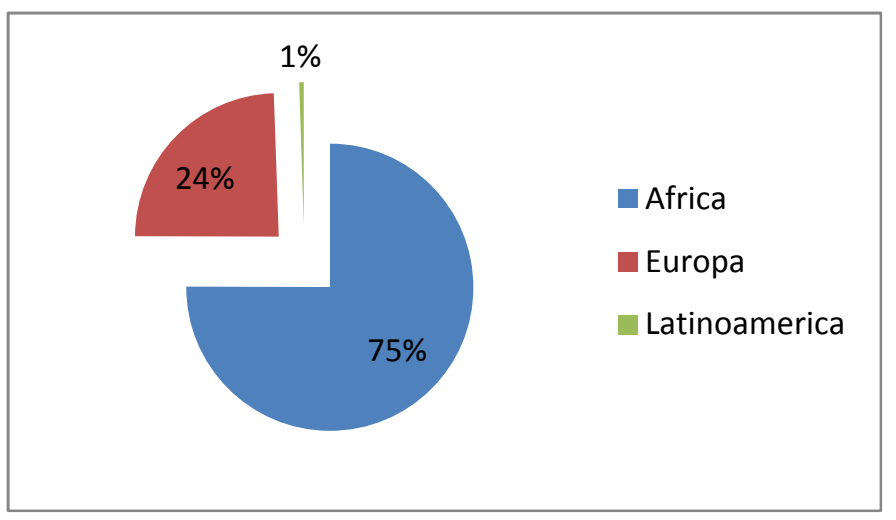

Fonte: Proaño et. al (2006) 


\subsubsection{Helicicultura na Colômbia}

Na Colômbia, segundo Niño e Torres (2013), a helicicultura é uma atividade passível de desenvolver em melhores condições, devido sua viabilidade geográfica e climática e a facilidade de iniciar a criação de caracóis com um investimento relativamente baixo. A criação de caracóis na Colômbia é uma atividade em desenvolvimento, mas legalmente aceita há mais de 15 anos - embora regulamentada somente em 2006. A primeira espécie de caracol cultivada no país para a comercialização foi introduzida ilegalmente no país em 1972. Neste mesmo ano, mediante um estudo de viabilidade feito entre a empresa Proexport e produtores franceses, foi determinado que esta atividade fosse viável na Colômbia, logrando-se obter benefícios econômicos (ZAMBRANO, 2015).

Já no início dos anos 1990, alguns helicicultores fizeram cultivos iniciais no Departamento de Bogotá, tendo os caracóis, posteriormente sido levados a outras regiões, e produzidos em pequenos espaços de terra de agricultores dos Departamentos de Antioquia, Boyacá, e Cundinamarca. Em cada uma das unidades de produção, as culturas abrigavam perto de 10.000 exemplares de caracóis ocupando uma área correspondente a $20 \mathrm{~m}^{2}$ de terra (ZAMBRANO, 2015).

Os estudos nesta área e a difusão a nível nacional do projeto de produção de caracóis foi feito pelos estudantes e profissionais da Fundação Agrária da Colômbia (UNIAGRARIA), os quais desenvolveram pesquisas e trabalhos de conclusão de curso em produção de caracóis a partir do ano de 1995. Assim, a difusão permitiu avançar e consolidar o projeto para que outras pessoas contribuíssem no processo. Logo, as universidades estatais e entidades privadas iniciaram-se os trabalhos de melhoramento das técnicas produtivas, cumprindo as normas exigidas pela União Europeia e procurando grandes volumes para exportar.

A necessidade de exportar grandes quantidades de caracol levou os produtores interessados a trabalharem agremiados, criando assim parâmetros e normativas de produção para o fortalecimento das organizações e cultivos. Estes produtores formaram legalmente associações de helicicultores e promoveram esta atividade mediante a capacitação, assessoria e projetos de pesquisas de novas técnicas de cultivo. Foi mediante tais iniciativas e empreendimentos que foi criada a primeira grande Associação Colombiana de Helicicultores Asocohelix, no ano 2001 (MONJE; GUTIERREZ, 2007).

Segundo Gomez e Bautista (2010), a formação de associações de helicicultores na Colômbia propiciou a exportação do caracol como carne (nas diferentes apresentações do produto: caracol temperado, em conserva, entre outros) e também como matéria-prima para as 
áreas de biomedicina, cosméticos e artesanato. Tal dinâmica proporciona, em média, três empregos diretos no processo produtivo, 12 empregos diretos e indiretos no processo de transformação e 15 empregos por tonelada produzida e transformada (MONJE; GUTIERREZ, 2007).

Hoje, na Colômbia, carecem dados oficiais e atualizados sobre a produção. Conforme apresenta Rodriguez et al. (2011), o país tem demonstrado potencial significativo para o desenvolvimento desta atividade, pois tem permitido a adaptação de espécies adequadas ao cultivo, mas não se tem estudos suficientes sobre o tema. Sabe-se, porém, que a produção tendeu-se a reduzir na última década.

Pinzón; Baracaldo e Ardila (2014) concorda com Rodriguez et al. (2011) com respeito à dificuldade de encontrar dados das exportações e importações de caracol na Colômbia. Contudo, dados estatísticos obtidos por Pinzón; Baracaldo e Ardila (2014 apud SAC), Quintero e Galindo (2007), Niño e Torres (2007) e Mejia et al. (2008) (Tabela 6) dão conta dos valores pagos nas exportações e toneladas líquidas do molusco para os anos de 2000 a 2012.

Estes dados apresentados na Tabela 6, contudo, não correspondem totalmente aos caracóis de terra; trata-se de uma visão geral dos moluscos cultivados na Colômbia. Pode-se observar, contudo, que, em geral, a produção e exportação diminuíram significativamente no período. Os períodos de maior exportação foram entre o ano 2000 e 2004. Segundo o ICA (2015), para o ano 2003 foi exigido dos produtores o registro expedido pelo mesmo Instituto, fato que ajudou na ampliação do crescimento das exportações para o ano 2004. Entretanto, nos anos seguintes (especialmente 2005, 2008, 2011 e 2012) a queda na exportação se acentuou, devido à falta de controle nos estabelecimentos produtores, não garantindo condições sanitárias exigidas para a exportação (ICA, 2015). 
Tabela 6- Volume e valor das exportações de carne de moluscos colombianos (entre 2003 e 2013), separados dos produtos vivos, frescos, congelados e secos.

\begin{tabular}{ccccc}
\hline ANO & $\begin{array}{c}\text { TONELADAS } \\
\text { LÍQUIDAS } \\
\text { EXPORTADAS }\end{array}$ & $\begin{array}{c}\text { MIL US\$ } \\
\text { FOB }^{2}\end{array}$ & $\begin{array}{c}\text { Caracol de } \\
\text { terra }\end{array}$ & $\begin{array}{c}\text { MIL US\$ } \\
\text { FOB }\end{array}$ \\
\hline 2003 & 97,69 & 623,95 & 64,883 & 459,981 \\
2004 & 146,74 & $1.130,20$ & 53,030 & 391,447 \\
2005 & 31,20 & 503,31 & 61,520 & 486,008 \\
2006 & 45,74 & 122,01 & 44,494 & 353,727 \\
2007 & 57,38 & 199,59 & & \\
2008 & 28,12 & 256,26 & & \\
2009 & 80,61 & $1.203,83$ & & 0 \\
2010 & 69,16 & 850,45 & 0 & 0 \\
2011 & 7,28 & 99,99 & 0 & 0,25 \\
2012 & 0,01 & 0,25 & 0,01 & \\
2013 & & & & \\
\hline
\end{tabular}

Fonte: Pinzón; Baracaldo; Ardila(2014apud SAC); Quintero e Galindo (2007); Niño e Torres (2007); Mejia et. al (2008)

Pinzon et. al (2014), porém, argumentam que os volumes de produção diminuíram devido a falta de organização das cadeias produtivas, que não garantiram a estabilidade do setor. Para estes autores, as exportações colombianas são muito baixas com respeito a mercado mundial, pela falta de conhecimentos nas culturas cultivadas; alguns produtores cultivam empiricamente procurando alcançar uma renda que permita sustentar sua família, mas não seguem as técnicas necessárias para garantir a qualidade necessária.

Para Quintero e Galindo (2007), Niño e Torres (2007) e o DANE (2015), os resultados da exportação de moluscos colombianos são desalentadores em consequência dos indicadores de produtividade do setor agrícola colombiano. Em muitas regiões poucas empresas helicicultoras conseguiram sucesso, mas outras foram fechadas.

Segundo Pinzón et al.(2014), na região andina colombiana, que é onde se pode encontrar maior desenvolvimento desta atividade, há baixo grau de produção e unidades com diferentes escalas de produção. Também, o Departamento de Cundinamarca oferece as melhores vantagens comparativas (clima, temperatura ideal, espécie silvestre existente etc.), além de condições logísticas para a comercialização internacional dos produtos helicícolas.

\footnotetext{
${ }^{2}$ FOB: (Free on Board) termino de comércio internacional no transporte de mercadorias.
} 
No Quadro 3 é possível observar alguns dos empreendimentos na Colômbia, por departamentos, alguns ativos e outros inativos.

Quadro 3- Empreendimentos helicícolas na Colômbia

\begin{tabular}{|c|c|c|c|}
\hline Departamento & Município & $\begin{array}{l}\text { Total } \\
\text { Empreendimentos }\end{array}$ & Total \\
\hline \multirow{6}{*}{ ANTIOQUIA } & El Retiro & 1 & \multirow{6}{*}{9} \\
\hline & Girardota & 1 & \\
\hline & Guarne & 1 & \\
\hline & La Ceja & 1 & \\
\hline & Rionegro & 3 & \\
\hline & Santa Elena & 2 & \\
\hline \multirow{5}{*}{ BOYACÁ } & Chiquinquirá & 1 & \multirow{5}{*}{5} \\
\hline & Duitama & 1 & \\
\hline & Guateque & 1 & \\
\hline & Tenza & 1 & \\
\hline & Tibiritá & 1 & \\
\hline CALDAS & Manizales & 1 & 1 \\
\hline \multirow{2}{*}{ CAUCA } & Piendamo & 1 & \multirow{2}{*}{2} \\
\hline & Timbio & 1 & \\
\hline \multirow{12}{*}{ CUNDINAMARCA } & Arbeláez & 1 & \multirow{12}{*}{15} \\
\hline & Cachipay & 1 & \\
\hline & Cajicá & 2 & \\
\hline & Chía & 1 & \\
\hline & Choachí & 1 & \\
\hline & Fómeque & 1 & \\
\hline & Fusagasuga & 1 & \\
\hline & La Calera & 1 & \\
\hline & Silvania & 2 & \\
\hline & Sisga & 1 & \\
\hline & Sopó & 1 & \\
\hline & Suesca & 2 & \\
\hline RISARALDA & Pereira & 2 & 2 \\
\hline SANTANDER & Lebrija & 2 & 2 \\
\hline \multirow{3}{*}{ VALLE DEL CAUCA } & Cerrito & 1 & \multirow{3}{*}{9} \\
\hline & Tulúa & 1 & \\
\hline & Outros & 7 & \\
\hline TOTAL & & & 45 \\
\hline
\end{tabular}

Fonte: Pinzón et. al (2014)

A produção destes empreendimentos é, de maneira geral, muito baixa para poder atender os requisitos da exportação. Para a Colômbia o desenvolvimento desta atividade mediante a pesquisa e investimento das técnicas, permitiria uma boa oportunidade para o setor agrícola, para os pequenos produtores de se associar para exportar e mudar suas condições de 
vida, contudo, há limitações que requerem maior apreciação - entre elas, a ampliação do volume de produção seria a mais importante, seguido pela manutenção de uma qualidade sustentável.

\subsection{Organizações}

Como base deste estudo, as organizações são muito importantes para a sociedade, e existem pela necessidade de oferecer bens e serviços, visando satisfazer as necessidades e desejos das pessoas, da comunidade, da sociedade. Para isto elas fazem análises do mercado, encontram necessidades ou as criam, e entram no jogo de intercambio cultural.

O termo 'organização' pode ser definido a partir de diferentes pontos de vista. Selznick (1972, p.19) define a organização como "instrumentos técnicos, planejados como meios para finalidades definidas. São julgadas como projetos; são perecíveis". Estas são projetadas para atingir metas, com sua vida própria. Já Colignon (1997, p.2) critica a definição do Selznick, argumentando que este apresenta a organização como "autônomas, apolíticas, associais e não históricas", pois, faz desaparecer o intercambio cultural entre o povo e as instituições. Por outro lado, Lapassade (1972) designa a organização como conjuntos práticos e processos sociais, pois devem organizar as tarefas de acordo com seus objetivos planejados e procurar alianças externas que contribuam para o desenvolvimento da organização. Já Robbins (1990) define a organização como uma entidade social com processos coordenados, com uma fronteira relativamente identificável, que funciona numa base relativamente contínua para alcançar objetivos comuns. E, finalmente, Motta (1979, p.11) conceitua organização como sendo...

[...] essencialmente uma instância de produção de bens, de conhecimentos, etc., bem como instâncias de controle, a serviço de sistemas sociais maiores. É o sistema social mais formalizado da sociedade, sendo, portanto, um sistema de significativas condutas institucionalizadas.

Com base nestas definições, pode-se dizer que uma organização é um conjunto de pessoas com capacidades e habilidades individuais, que se unem para alcançar um objetivo comum e proporcionar um serviço à comunidade. As organizações são dinâmicas, adaptáveis às mudanças do entorno, possuem uma cultura definida, com características especiais que as diferenciam das outras organizações, e que tem como finalidade se institucionalizar. Este dinamismo faz com que as organizações programem novas práticas e procedimentos definidos 
mediante o trabalho organizacional e institucionalizados da sociedade (POWELL; DiMAGGIO, 1972).

Com tal fim as organizações, segundo Da Cunha et. al (2011), cada dia, adotam e intensificam novas estratégias de gestão que lhes permitam se apresentar frente à sociedade como organizações mais homogêneas, com um alto grau de eficiência e eficácia, que lhes possibilite se diferenciarem das outras organizações do mercado. Quando elas identificam perspectivas diferentes sobre a influência que sofrem do ambiente onde se desenvolve, conseguem criar um espaço próprio.

Para dar explicação daquelas estratégias distintivas, daqueles que tomam as decisões, estas devem estar baseadas na análise do entorno dinâmico do mercado, devem aceitar as mudanças em todos os níveis organizacionais de acordo com as necessidades da sociedade, e determinar uma reorganização dos processos de gestão. As mudanças econômicas, políticas e sociais mexem também, e fundamentalmente, com as relações humanas internamente e externamente à organização. Nesse contexto, consumidores, colaboradores, acionistas e fornecedores passam a ser mais exigentes no estabelecimento de suas relações com as organizações (SILVEIRA; GARCIA, 2010). Igualmente como desafio para as organizações estão os avanços e as inovações, principalmente da tecnologia, a gestão de pessoas e o ambiente no qual estão inseridas.

As organizações usam a neutralidade ideológica para escapar da força das tradições que de outro modo, restringem o escopo e o soberano exercício de sua competência para delinear seus próprios programas. Assim como as pessoas são, enquanto membros das organizações, arrancadas das estruturas de personalidade e neutralizadas por meio da atribuição de padrões de desempenho, assim também tradições culturais e ideologias são roubadas de seu poder de união e convertidas em matéria-prima para os propósitos de planejamento ideológico, isto é, para um processamento administrativo das constelações de significado (HABERMAS, 1987, p.308). As organizações, como foco de diferentes estudos, precisam de uma análise organizacional para avaliar seu entorno, conhecer pontos fracos para melhorar e infundir seus valores à sociedade.

Como objeto de estudo as organizações rurais podem ser entendidas como o regimento estabelecido formalmente por determinados grupos de pessoas no meio rural, que procuram um desenvolvimento da região e obter lucros pelos produtos cultivados, neste caso Helicicultores. Este grupo de pessoas ou produtores rurais está integrado em cadeias produtivas relacionadas aos diferentes produtos (RODRIGUEZ et al., 2011). 


\subsubsection{Análise Organizacional}

O processo da análise organizacional segundo Sierra (2009), afirma que apresenta o desempenho e o jeito de operação de forma interna; delimitado no âmbito da identidade como sistema social. Este processo faz uma analise o comportamento organizacional, a influência dos indivíduos, grupos, estruturas e decisões no funcionamento da organização, como fim de obter objetivos planejados.

Para autores como Amorós (2007 p.7); Braidot (2003, p.4), trata-se de uma avaliação a nível de gestão de pessoas, estrutura organizativa, impacto do médio interno e externo da organização, que permitiria uma mudança de um estado de incerteza a um de conhecimento atual para visar a direção adequada na empresa e assim melhorar a eficácia e eficiência da organização. No entanto, estas observações e análises deixam sempre aspetos invisíveis para os observadores, razão pela qual expressa Rodriguez (1999, p. 33) "o diagnóstico organizacional deve ser sempre um co-diagnóstico, que o observador de fora tem que cooperar com o observador interno para encontrarem a identificação conjunta de problemas e alternativas da organização".

Assim, para Sierra (2009), a análise organizacional deve oferecer uma observação relativamente simples da realidade organizacional destacando aspetos positivos e melhorando os negativos, tendo presente os objetivos da organização e sendo fiel à representação da operação organizacional, sem se afastar do contexto sistêmico e global da organização, ligando variáveis entre si com os resultados da organização, de modo determinar as relações causais. O objetivo é o de prever o impacto de diferentes eventos produtividade organização e o bem-estar dos seus membros.

Pode-se concluir que a análise organizacional é o processo mais importante para a organização, é se conhecer internamente, conhecer seu desempenho para chegar ao diagnóstico certo que permita distinguir os pontos fortes, tomar decisões para melhorar os pontos fracos, lograr harmonia entre os participantes, com o objetivo de melhorar a produtividade da organização e conseguir institucionalizar.

\subsection{Instituições}

Uma organização, ao ser criada, consolida elementos sociais e culturais da sociedade. A estes elementos, resultam as instituições. O primeiro a adotar o termo 'instituição' foi Everett Hughes (PECI, 2006). Hughes (1936) adotou a definição através da antropologia, 
definindo as instituições como fenômenos sociais analisados pelo comportamento coletivo, e como um empreendimento social. Para ele as instituições satisfazem as necessidades definidas pelas pessoas unidas em organizações. E, de fato, o estudo das instituições é o estudo da sociedade em ação, ainda que de uma ação que transcorre nos limites de formas sociais solidamente estabelecidas (HUGHES, 1942).

A permanência das instituições não somente vão ao jeito de satisfazer as necessidades humanas culturalmente definidas, mas também nas relações com o meio externo, o intercâmbio de valores entre a organização e a sociedade (HUGHES, 1936). Estas devem ter uma troca de experiências culturais, políticas e sociais que permitam que as organizações se institucionalizem, ou seja, adquiram uma identidade própria, aceitável pela sociedade e possa ser reconhecida pela qualidade de bens e serviços que esta oferece.

Já Selznick (1972) define a instituição como um organismo adaptável e receptivo. A instituição é influenciada pelo meio social. Segundo Selznick (1972), as instituições são concebidas como grupos ou práticas, podem ser parcialmente planejados, mas possuem também uma dimensão natural. São produtos de interação e adaptação; tornam-se os receptáculos do idealismo de um grupo e são menos facilmente perecíveis.

Entre outras definições, Lapassade (1985) interpreta as instituições como entidades de uma própria identidade, que tem ideias, valores e leis que determinam as maneiras de intercambio social. Já, segundo Scott (1994), as instituições são sistemas simbólicos e de comportamento que contêm regras representacionais, constitutivas e normativas, as quais, junto com mecanismos regulatórios, definem um sistema comum de significados e avaliação dos processos das organizações, e se originam de atores e rotinas de ações distintas. Assim, o foco da análise são as estruturas normativas e cognitivas que proveem significado e estabilidade para a vida social. Entretanto para North (1998), as instituições são os modelos para a realização das trocas e fazem a relação com os custos de transação. Assim define as instituições...

[...] como um conjunto de regras, procedimentos de aceitação e seu cumprimento, normas éticas e morais de comportamento que são projetadas para delimitar o comportamento dos indivíduos com o objetivo de maximizar a riqueza ou a utilidade dos governantes e sujeitos principais da sociedade.

Fazendo uma análise das definições das instituições, pode-se dizer que elas são organismos criados para manter uma ordem e controlar a sociedade. São padrões de 
comportamento, regras normativas que as organizações devem cumprir para suas funções de desenvolvimento buscando ótimos resultados frente à sociedade.

\subsubsection{Institucionalização}

As organizações, que apesar de serem ferramentas, possuem vida própria SELZNICK (1949), e uma necessidade se institucionalizar, e assim, alcançar uma posição importante e de maior reconhecimento frente à sociedade pelos produtos ou serviços oferecidos. Segundo Da Cunha et al. (2011) as organizações passam a simbolizar as aspirações da comunidade. Para a visão de Selznick (1972, p.14) a institucionalização é um processo que acontece dia a dia com o passar do tempo. Baseado na cultura dessa organização o mais importante é infundir um valor e alcançar uma identidade própria, distinta, que lhe permitirá ser acolhida pela sociedade. Segundo os autores Powell e DiMaggio (2001, p.129) a "institucionalização é um processo com propriedade variável, por meio do qual os atores individuais transmitem o que socialmente é definido como real. Simplesmente define uma realidade social que será transmitida e conservada como um feito".

Para eles o processo de institucionalização simplesmente define uma realidade social, que será transmitida e conservada como um feito. (POWELL; DiMAGGIO, 2001)Para que as organizações possam alcançar um grande grau de institucionalização elas devem ter um...

[...] conjunto de regras (formais e informais) e restrições com habilidade para conformar as relações entre os indivíduos (fatores humanos) e grupos de indivíduos (áreas, subáreas, grupos informais) para o cumprimento da missão da organização. $\mathrm{O}$ conjunto de regras e restrições refere-se às prescrições comuns que devem ser estabelecidas para ordenar os relacionamentos repetitivos e interdependentes estabelecidos entre os membros organizacionais (DOS SANTOS et al., 2007, p. 6).

Segundo os mesmos autores, os hábitos e rotinas permitem que os traços organizacionais sejam transmitidos através do tempo. Assim, as organizações mudam lentamente ao seguir um conjunto de hábitos e rotinas de forma programática, de acordo com as regras formais e informais que os sustentam. As rotinas são os hábitos da organização e compõem as várias instituições existentes, são as formas estabelecidas de pensamento comuns aos membros da organização e passam com o tempo a serem suportadas pelo conhecimento tácito dos atores organizacionais e pela monitoração reflexiva do comportamento passado. 
Complementando com as opiniões de Selznick (1996) este autor afirma que a “institucionalização é uma ideia neutra, que pode ser definida como a emergência de padrões socialmente integradores, ordeiros e estáveis a partir de atividades instáveis, frouxamente organizadas e estreitas. Implica, assim, uma ideia de permanência, pois o teste dessa institucionalização é a dispensabilidade, ou seja, a prontidão com que a organização ou prática é abandonada ou mudada em resposta a novas circunstâncias ou demandas".

Por outro lado Da Cunha et al (2011, p. 10), afirmam que as organizações passam pela habitualização, que precede a institucionalização:

\begin{abstract}
A institucionalização ocorre sempre que há uma tipificação recíproca de ações habituais por tipos de atores, são construídas no curso de uma história compartilhada. Não podem ser criadas instantaneamente. As instituições têm sempre uma história, da qual são produtos. É impossível compreender adequadamente uma instituição sem entender o processo histórico em que foi produzida... Dizer que um segmento da atividade humana foi institucionalizado já é dizer que ele foi submetido ao controle social.
\end{abstract}

Deste modo, o processo de institucionalização é de grande importância, já que ajuda as organizações a adquirirem uma identidade própria frente ao isomorfismo que muitas organizações apresentam, contribuem para ter uma estrutura organizacional e institucional estável. Estas estruturas podem ser analisadas desde o ponto de vista de Peci (2006) que afirma que estas nascem principalmente de processos intergrupais e organizacionais; processos e estruturas organizacionais formais que não somente tendem a ser altamente institucionalizados, mas servem também como fonte de nova institucionalização. 
Quadro 4- Níveis de análise da Nova teoria Institucional

\begin{tabular}{|c|c|c|c|}
\hline $\begin{array}{c}\text { Contexto da } \\
\text { institucionalização }\end{array}$ & Abrangência & $\begin{array}{l}\text { Fonte primária de } \\
\text { Institucionalização }\end{array}$ & Problemática \\
\hline Contexto institucional & $\begin{array}{l}\text { "posições políticas, programas } \\
\text { e procedimentos da moderna } \\
\text { organização [...] são } \\
\text { manifestações de poderosas } \\
\text { regras institucionais que } \\
\text { funcionam como mitos } \\
\text { altamente racionalizados" } \\
\text { (Meyer e Rowan, 1977, p.343) }\end{array}$ & Estado & $\begin{array}{l}\text { As organizações tornam-se } \\
\text { "audiência" passiva de } \\
\text { conhecimento } \\
\text { institucional, porque as } \\
\text { regras formam-se a partir } \\
\text { do Estado ou até do } \\
\text { sistema mundial }\end{array}$ \\
\hline Campo organizacional & $\begin{array}{c}\text { "Organizações que, em suma, } \\
\text { constituem um campo } \\
\text { reconhecido de vida } \\
\text { institucional" (DiMaggio e } \\
\text { Powell, 1983, p.148) }\end{array}$ & $\begin{array}{c}\text { Redes } \\
\text { interorganizacionais }\end{array}$ & $\begin{array}{c}\text { Embora a maioria das } \\
\text { relações possam ser } \\
\text { estabelecidas entre as } \\
\text { organizações do mesmo } \\
\text { "campo", a } \\
\text { institucionalização pode } \\
\text { transcender as fronteiras de } \\
\text { um único campo }\end{array}$ \\
\hline $\begin{array}{l}\text { Estrutura interna da } \\
\text { organização }\end{array}$ & $\begin{array}{l}\text { Organização isolada, às vezes, } \\
\text { redes interorganizacionais }\end{array}$ & $\begin{array}{l}\text { Indivíduos interagindo } \\
\text { nas organizações }\end{array}$ & $\begin{array}{l}\text { Não consegue estabelecer } \\
\text { um esquema teórico } \\
\text { coerente, que possa levar } \\
\text { em consideração o } \\
\text { ambiente institucional }\end{array}$ \\
\hline
\end{tabular}

Fonte: Peci (2006)

No Quadro 4, destaca-se os três níveis de análise que prevalecem na escola institucional, apontando o contexto de institucionalização, a abrangência da definição com a qual se trabalha empiricamente, a fonte primária de institucionalização e as problemáticas decorrentes de cada perspectiva, assim as organizações conseguem absorver e infundir valores à sociedade, pois num momento de mudanças pode ter ajuda e respaldo desta. Os valores fazem parte da cultura, ou seja, o processo de institucionalização envolve diretamente a cultura (PECI, 2006 p. 9).

\subsection{Organizações e Instituições na Helicicultura na Colômbia}

No contexto colombiano, segundo Rodriguez et al. (2011), as unidades de produção de caracóis estão representadas por um segmento de pequenos produtores que têm os recursos (terra e mão-de-obra) de baixa qualidade e / ou quantidade. Contudo, há uma cadeia de fornecimento minimamente formalizada, o que permite que essas pessoas possam gerar mais valor em seus cultivos e obter maiores benefícios, tais como: acesso à tecnologia, crédito, parceria na comercialização etc.

De acordo com Rodriguez et al. (2011), esta atividade, até o ano 2011, foi desenvolvida por aproximadamente 80 mil pequenos produtores no âmbito nacional, segundo dados subministrados pela Federación Colombiana de Helicicultores (FEDECOHEL), sendo 
que $70 \%$ deles mantêm a produção nas condições de informalidades técnica e administrativa, com gestão organizacional empírica e baixa tecnologia; trabalham de forma isolada, com poucos recursos financeiros para os investimentos, seus processos produtivos e de marketing e com pouca inovação e altas exigências para as licenças ambientais, o que gera sua baixa produtividade e competitividade em nível nacional e internacional.

Mediante esta situação, muitas universidades privadas e entidades estatais, como o SENA (Serviço Nacional de Aprendizagem), têm desenvolvido trabalhos de investigação e melhoramento dos processos produtivos, buscando avaliar a produção de caracóis de forma a cumprir os regulamentos ambientais exigidas pelos países importadores, ou seja, as autoridades europeias. Com os esforços da Universidade António Nariño de Bogotá, por exemplo, e o apoio do Ministério de Agricultura, buscou-se identificar e definir a cadeia produtiva do caracol de terra na cidade de Cundinamarca, com a qual se trabalha a cadeia produtiva na Colômbia (ZAMBRANO, 2015).

A regularização da criação nacional de caracol, na Colômbia, ocorreu no ano de 2006, mediante Lei 1011. Durante o ano de 2006 e o ano seguinte se incrementaram os cultivos de caracol dando estrito cumprimento às exigências das autoridades nacionais. Houve o desenvolvimento dos cultivos em estufas para cria e produção, além de melhor controle sanitário e limpeza nas instalações e equipamentos utilizados (QUINTERO; GALINDO, 2007).

Posteriormente, o decreto 4064 de 24 de outubro de 2008, expedido pelo Ministério do Meio Ambiente, permitiu que os diferentes cultivos solicitassem suas licenças ambientais. Segundo Quintero e Galindo (2007) e Gomez e Bautista (2010), nos anos de suas pesquisas, se tinha conhecimento de apenas 10 licenças ambientais experimentais.

Em 2009, o ICONTEC, em colaboração com os helicicultores elaborou as normas para a obtenção do Certificado de Qualidade ISO 14000. Conforme Rodriguez et al. (2011), o referido Instituto gerou normas técnicas para o produto e o processo de cultivo tais como: Norma Técnica NTC 5591, para caracol de terra vivo ou semente; Norma Técnica NTC 5603 para cultivo de caracol de terra; Norma Técnica NTC 5611 para caracol de terra congelado, cru, cozido ou pré-cozido; Norma Técnica NTC 5668 para caracol de terra preservado; Norma Técnica NTC 5669 para baba de caracol de terra ou extrato proteico natural do caracol.

Em continuidade ao processo de legalização da atividade, o ICA, "responsável por exercer ações de sanidade agropecuária e controle técnico das importações, exportações, manufatura, comercialização e uso dos insumos agropecuários destinados a proteção da produção agropecuária nacional e minimizar riscos alimentícios e ambientais”, emitiu a 
Resolução 1.464 de 2010, onde se estabelece os requerimentos para registro e condições sanitárias para os locais produtores de caracol de terra Helix aspersa.

Segundo dados apresentados Rodriguez et al. (2011), entre os cultivos destacados da Asocohelix com aplicação das norma ICONTEC estão: SISGA e Colégio Cajicá (SCARCOL), com produção de uma tonelada ao mês cada um; TENSA (Boyacá), com três toneladas mensais; SILVANIA, com $500 \mathrm{Kg}$; DISTRIREVE, entre outros da Fundação no Valle do Cauca; PIENDAMÓ (Cauca); HELICOL (Duitama) com uma produção anual de aproximadamente uma tonelada.

Vale destacar, ainda, que a Câmara do Comércio de Bogotá outorgou aos produtores o código CIIU (Industrial Internacional Uniforme) que representa a classificação sistemática de uma atividade econômica para, cultivo, exploração e comercialização do cultivo de espécies menores, e definiu a posição tarifária para a comercialização de caracol, correspondente ao código 0307.60.00 ("caracóis, exceto os de mar, vivos, frescos, refrigerados, congelados, salgados, secos ou em salmora") e 0307.60.00.100 ("caracóis de terra Helix aspersa)" e 0307.60.00.900 “outros caracóis”) (RODRIGUEZ et al., 2011).

\subsection{Redes e Ação coletiva}

Redes, segundo Olivieri (2003), são sistemas organizacionais onde são envolvidos indivíduos e instituições, de forma democrática e participativa, em torno de causas afins e os objetivos planejados. Estruturas flexíveis e estabelecidas horizontalmente; o trabalho dinâmico entre elas supõe atuações colaborativas e se sustenta pela vontade e afinidade de seus integrantes, caracterizando-se como um significativo recurso organizacional para a estruturação social. O objetivo principal das redes é possibilitar às empresas responder ao ambiente competitivo, por meio de ações uniformizadas em uma única estrutura, mas, de forma flexível por parte das empresas associadas. (PEREIRA, 2014)

O princípio básico das redes é o de que a estrutura das relações sociais determina o conteúdo dessas relações. Os teóricos das redes rejeitam a noção de que as pessoas são combinações de atributos, ou de que as instituições são entidades estáticas com limites claramente definidos (BRAGA, 2009). Assim, Freitas (2005apud PEREIRA 2014) argumenta que uma efetiva cooperação requer coordenação, uma vez que os membros de uma rede possuem diversidades de comportamento, de prioridades, de motivações e de percepções do ambiente. Nesse sentido, a coordenação traz maior ordenação para a uma atuação eficiente, considerando os objetivos comuns. Estas estruturas de rede constituem um cenário de 
referência, que pode ser aplicável à determinação de fenômenos caracterizados pelos relacionamentos cooperativos entre os agentes, o que reforça a necessidade de uma coordenação coletiva para ações que vierem a ser adotadas.

Concluindo com o afirmado por Sulbrandt et. al (2001), as redes são estruturas de interdependência que envolvem múltiplas organizações e os elementos que as compõem mas não são subordinadas em termos hierárquicos. Apresentam um grau de estabilidade estrutural e chegam a ter vínculos mais fortes que os descritos nas políticas de associação. Apresentam uma solução viável e desejável aos cidadãos ativos e conscientes das necessidades de transformações do mundo. As redes possibilitam a articulação dos movimentos culturais e informacionais capazes de propor alternativas de surgimento para a humanidade (OLIVIERI, 2003).

As redes organizacionais são um sistema de organizações e relações de troca e cooperação de experiências, trabalho, valores, orientadas ao benefício mútuo, que adquire uma configuração de processo com laços tecidos de interação (LÓPEZ, 2004).

Por sua parte Perucci e Potter (1989 p.8), para alcançar um grande impacto nas economias, tanto nacional como internacional, se deve ter grandes conexões entre as organizações, ponto forte das redes organizacionais. Outra característica das redes organizacionais citada por López (2004) é que as relações que são formadas entre as organizações e seus participantes baseadas na comunicação que se pode dar entre eles, a qual tem que ser contínua, transparente, ágil e deve-se apresentar por qualquer meio de comunicação nas diferentes direções (horizontal - vertical). Mediante esta comunicação podese dar a troca de conhecimentos, meios materiais e influências, garantindo a reciprocidade, a fim de manter o equilíbrio da rede.

Sobre a cooperação, López (2004) afirma que fundamentalmente trata-se de uma ação conjunta baseada na complementaridade no momento do intercâmbio. Numa rede que vai crescendo, vai-se desenvolvendo ações conjuntas, não só para o benefício mútuo, como também para conhecer a realidade onde se desenvolvem. O benefício mútuo ocorre fazendo com que todas as organizações envolvidas ganham, consolidando metas comuns. A flexibilidade é uma característica que também se deve ter para se formar uma rede. A criação de uma rede organizacional requer o reconhecimento à diversidade de quem tece e de quem possui potencialidade. Deve fortalecer a sua identidade, a partir da construção das identidades dos seus participantes. 
Assim, as redes organizacionais constituem, segundo Cardoso, Alvarez e Caulliraux (2002), formas organizacionais que buscam a obtenção de melhores resultados globais para um conjunto de empresas e não para cada uma individualmente, através da coordenação do trabalho e do aproveitamento sistêmico de recursos existentes nas empresas que as compõem. Uma rede cuja competitividade individual dos participantes tenha aumentado em determinado período, mas na qual há uma gradativa deterioração na qualidade dos relacionamentos, por exemplo, tende a gerar resultados negativos no futuro, sem que esse cenário seja adequadamente percebido simplesmente pela avaliação individual das empresas. Além disso, Cardoso, Alvarez e Caulliraux (2002) deixam claro que a rede representa o conjunto de organizações que desempenha funções compartilhadas, de maneira que se acentuam as relações de dependência e de interligações entre as empresas. Isso significa que, de certa forma, a qualidade das ligações entre as empresas é tão ou mais importante do que exclusivamente o compartilhamento de recursos e funções entre os participantes.

As redes ocorrem tanto em grupos de organizações multinacionais, complexas e estruturadas, como podem coexistir em pequenas organizações, micro empresas urbanas ou rurais. Neste caso, a ação coletiva consolida as vantagens do grupo.

O termo 'ação coletiva', segundo Olson (1985 p.203), trata-se da "manifestação da conduta dos grupos". Não tem sentido a individualização do objetivo principal se há pessoas com interesses comuns e que unidos possam lograr maiores resultados.

A ação coletiva, segundo autores como Melucci (1996) e Leal (1998), requer uma análise do processo de intenções, recursos e limites da rede, promovida por um representante mediante relações sociais desenvolvidas num sistema de oportunidades e obrigações. Requer uma coordenação de esforços de duas ou mais pessoas, as quais nascem de uma necessidade individual. As ações de uma pessoa dependem da ação da outra. Por tanto para estes autores os elementos essenciais de uma ação coletiva estão representados pela existência de um representante, a proteção de um direito de grupo e o efeito de uma ação numa pessoa sobre o grupo.

Já Diniz et. al. (2006) afirma que uma ação coletiva é empreendida por um conjunto de atores econômicos (empresas ou instituições) independentes que se associam voluntariamente para lograr um objetivo comum, mantendo sua individualidade. Estas variam segundo os atores participantes e o grau de colaboração entre eles. Podem ser empreendidas por pequenos grupos de empresas ou por uma pluralidade mais numerosa de 4 (quatro) pessoas ou sócios das organizações. São importantes estas ações porque permite que as empresas potencias reafirmem suas capacidades de aprendizagem, reduzindo a incerteza nos processos de tomada 
de decisões, favorecendo empresas pequenas ao alcance de economias de escala e o aumento de seu poder de negociação.

Finalmente unindo os dois termos, redes e ação coletiva, segundo Diez e Emilozzi (2015), favorece a otimização dos recursos e dos fatores de produção das organizações, aproveitando recursos subutilizados ou estabelecendo combinações entre eles. Através destas iniciativas conjuntas, os atores locais se comunicam, trocando conhecimentos e habilidades que permitem a construção de espaços de trabalho comuns, facilitando o desenvolvimento de projetos e inovações. Harrigan (1992) apresenta as vantagens desta cooperação: benefícios internos (que permitem compartilhar riscos, melhorar a informação e evitar duplicação de esforços); benefícios competitivos (colaboração entre diversos agentes constituem uma ferramenta eficaz para promover sectores industriais específicos e alcançar uma melhor posição na economia); benefícios estratégicos (promovendo a sinergia entre os atores, a transferência de conhecimentos e tecnologia e a ampliação do portfólio de produtos incentivando novas atividades produtivas).

\subsubsection{Ação coletiva e redes na Helicicultura colombiana}

Segundo Rodriguez et al., (2011), na Colômbia, 70\% dos helicicultores são famílias proprietárias de pequenas extensões de terra, que produzem o molusco com grande informalidade técnica e administrativa, com gestão organizacional empírica e com baixo grau tecnológico. Esta atividade ainda não tem definida uma cadeia produtiva completa, o que dificulta os processos de desenvolvimento. Algumas organizações ainda desempenham a atividade de forma isolada. Segundo o mesmo autor, eles trabalham para seu beneficio próprio, seu próprio lucro, mais não coletivamente. Alguns dos produtores, porém, optaram por tecer redes e contribuir com conhecimentos para obter uma grande produção.

Para Rodriguez et al. (2011), se houvesse uma cadeia produtiva formalizada permitiria que essas pessoas pudessem gerar maior valor a seus cultivos. Assim, eles passariam a ter maior acesso a tecnologia, crédito e associatividade, permitindo maior competitividade e mais altos níveis de produção. Isso também poderia lhes permitir um padrão de produção de qualidade internacional do produto, favorecendo o aumento dos seus níveis de produção e de produtividade. A organização coletiva requer a interação entre os componentes (internos e externos), formando redes e permitindo, como resultado, a maior eficácia no alcance de seus objetivos. 
Na Colômbia a oferta coletiva de trabalho familiar corresponde ao principal capital destas organizações, que são consolidadas a partir da união de sua própria individualidade, impedindo, por conseguinte, a restrição de mercado. (RODRIGUEZ et al., 2011)

Para desenvolver esta ou outra atividade produtiva, segundo Galloti (2014), integrante da Associação Nacional de Helicicultores de Argentina, é importante saber que a melhor maneira para "crescer" é se associar com outros produtores, e consequentemente, alcançar maiores resultados nos processos de exportação. Para ele, as associações facilitam a conquista de novos mercados, em grandes escalas, integrando cadeias produtivas (na compra de sementes a baixos preços, venda da produção em maiores preços e ganhos em assessoramento mais econômico), e assim logrando grandes volumes de vendas e de qualidade na produção. Também, segundo a Associação de Helicicultores de Andalucia (2014), na Espanha, as associações têm como objetivo o assessoramento dos associados para manter e obter resultados competitivos, procurar a melhoria dos cultivos, capacitar a mão de obra, garantir bom clima organizacional e, o mais relevante, obter uma boa relação entre as organizações envolvidas na atividade com o governo, respondendo os interesses institucionais relacionados ao meio ambiente e demais instituições que regulam as condições requeridas para o manejo destas espécies.

No caso dos produtores colombianos que optaram pela ação coletiva, segundo Rodriguez et al. (2011), estes foram organizados em pequenos grupos de empresas familiares de sua região e cultivam este produto nos diferentes departamentos do País. Estas organizações rurais foram envolvidas em duas redes de helicicultores: a grande Federação Colombiana de Helicicultura 'Fedecohel' e a Associação Colombiana de Helicicultores 'Asocohelix', que nasceram com o objetivo de agrupar os pequenos produtores e garantir benefícios para seus cultivos e os mercados. As duas associações nasceram no ano 2001 para contribuir com a regulamentação da atividade, visando brindar garantias aos helicicultores. Contribuíram ao desenvolvimento e cumprimento da lei, promoveram seminários, palestras e assessorias para as famílias que fizeram parte das redes. Hoje em dia só existe a Asocohelix que ainda estimula os associados com projetos de cultivo de caracol. 


\section{METODOLOGIA}

A abordagem desta pesquisa pode se caracterizar como qualitativa buscando o porquê das coisas, e quantitativa enquanto da análise de dados estatísticos, as relações entre variáveis, e a imersão em dados obtidos por grupos de pessoas que desenvolvem a atividade da helicicultura. Envolveu uma análise histórico-comparativa que segundo Cañizares (2008) é um método das ciências sociais que estuda os acontecimentos históricos dos fenômenos culturais, sociais na procura de respostas válidas no tempo e no espaço, encontrando uma origem comum. Trata-se da comparação de processos sociais através dos tempos e lugares. Para Mahoney e Reuschmeyer (2006 apud Brisola 2013) estes estudos representam investigações científico-sociais que envolvem fatos históricos e teorias para aproximarem-se as causas dos fenômenos. O período histórico desta análise compreende os últimos 10 anos (2003-2013) de desenvolvimento desta atividade, período que sofreu muitas mudanças devido a fatores políticos, sociais e culturais.

A pesquisa levou em consideração uma análise do entorno externo para conhecer os aspetos institucionais, entenda-se segundo Ramirez (2014) como sendo as características que envolvem fatores econômicos, tecnológicos, jurídicos, políticos, sociais, culturais, ecológicos que afetam os processos da empresa no nível geográfico ou numa determinada sociedade. Em particular aquelas forças específicas que podem afetar o desenvolvimento e o sucesso da empresa, compostas pelos fornecedores, clientes, e competência das instituições que regulamentam as atividades empresariais, e o entorno interno em quanto aos aspetos organizacionais que envolvem esta atividade. Entenda-se por ambiente interno como uma série de características inerentes à empresa, as quais são percebidas e influenciam nos atores participantes, dependendo dos fatores do meio onde se desenvolvem. Pode-se denominar clima organizacional (RAMIREZ, 2014).

\subsection{Instrumentos e procedimentos para a coleta dos dados}

Foi preciso para a coleta de dados uma pesquisa documental que segundo Gil (2008) utiliza material que ainda não receberam um tratamento analítico ou que podem ser reelaborados de acordo com os objetivos planejados na pesquisa, são analisados documentos de "primeira mão" e alguns que já foram processados, mas podem receber outras interpretações. 
Fundamentalmente os documentos analisados apresentados no Quadro 5 foram pertencentes à organizações, ao governo, documentos públicos, arquivos das licenças ambientais dos empreendimentos de instituições como: Ministério do Meio Ambiente, Ministério de Agricultura, Autoridade Nacional de Licenças Ambientais (ANLA), Corporações Autônomas Regionais (CRC), Instituto Colombiano Agropecuário, Instituto Colombiano de Normas Técnicas (ICONTEC), Departamento Administrativo Nacional de Estatística (DANE) e Procolombia, Banco Agrário de Colômbia e finalmente as Unidades Municipais de Assistência Técnica (UMATA), organizações como Asocohelix e Helix del Sur Colômbia. Conquanto, foram utilizadas fontes secundárias para ter acesso a algumas informações: artigos, livros, dissertações e trabalhos de conclusão de curso etc.

Quadro 5. Fontes da pesquisa documental e bibliográfica utilizada

\begin{tabular}{|c|c|c|c|}
\hline Ano & Tipo de Documento & Título (original) & Autor/Organização \\
\hline 1993 & Documento do Governo & Ley 99 & $\begin{array}{l}\text { Gestão ambiental nacional, } \\
\text { criação do Ministério do Meio } \\
\text { Ambiente. }\end{array}$ \\
\hline 1994 & Documento do Governo & Ley 165 & $\begin{array}{l}\text { Convênio das Nações Unidas } \\
\text { pela diversidade biológica. }\end{array}$ \\
\hline 2000 & Documento do Governo & Ley 611 & $\begin{array}{l}\text { Norma para o manejo } \\
\text { sustentável de espécies de } \\
\text { fauna Silvestre e aquática. }\end{array}$ \\
\hline 2001 & Documento do Governo & Resolución 0438 & $\begin{array}{l}\text { Salvo-conduto único nacional } \\
\text { para a mobilização de espécies } \\
\text { da diversidade biológica }\end{array}$ \\
\hline 2003 & Artigo & La Helicicultura & $\begin{array}{l}\text { R. López Pereyra, L. } \\
\text { Maiorano, N. Raimondi, C. } \\
\text { Ybalo }\end{array}$ \\
\hline 2004 & $\begin{array}{l}\text { Trabalho de conclusão de } \\
\text { curso }\end{array}$ & $\begin{array}{l}\text { Evaluacion técnica econômica de uma } \\
\text { crianza intensiva de caracoles (Helix } \\
\text { aspersa) }\end{array}$ & $\begin{array}{l}\text { Marcela Bernardita Benito } \\
\text { Lagos }\end{array}$ \\
\hline 2006 & Monografia de Mestrado & $\begin{array}{l}\text { Helicicultura. La cría de caracoles en la } \\
\text { Argentina: una alternativa innovadora } \\
\text { de agronegcios }\end{array}$ & Raquel F. Sastre \\
\hline 2006 & $\begin{array}{l}\text { Trabalho de Conclusão de } \\
\text { Curso }\end{array}$ & Heliciculturaen Rio Bueno & $\begin{array}{l}\text { Manuel Roberto Espinoza } \\
\text { Salinas }\end{array}$ \\
\hline 2006 & Monografia de Mestrado & $\begin{array}{l}\text { Diseño de un modelo de negocio de } \\
\text { exportación de un producto no } \\
\text { tradicional, El Helixaspersamuller }\end{array}$ & $\begin{array}{l}\text { Martin López Proaño, Mariano } \\
\text { Phang Lema, Ricardo Rossi } \\
\text { Valverde }\end{array}$ \\
\hline 2006 & $\begin{array}{l}\text { Monografia de } \\
\text { Licenciatura }\end{array}$ & $\begin{array}{l}\text { Apuntes- Producciones Ganaderas } \\
\text { alternativas }\end{array}$ & $\begin{array}{l}\text { Dr. José Manuel Perea Muñoz, } \\
\text { Dr. Antón García Martínez, } \\
\text { Dra. Raquel Acero de la Cruz }\end{array}$ \\
\hline 2006 & $\begin{array}{l}\text { Trabalho de Conclusão de } \\
\text { Curso }\end{array}$ & $\begin{array}{l}\text { Estúdio técnico econômico para } \\
\text { lainstalacion de um criadero de } \\
\text { caracoles comestibles terrestres }\end{array}$ & Guillermo SonodaFujimoto \\
\hline 2006 & $\begin{array}{l}\text { Documento do Ministério } \\
\text { da Agricultura }\end{array}$ & Ley 1011 & $\begin{array}{l}\text { Pela qual autoriza e } \\
\text { regulamenta atividade da } \\
\text { helicicultura e dita outras } \\
\text { considerações }\end{array}$ \\
\hline 2007 & Trabalho de Conclusão de & Factibilidade para eldesarrollo de um & Luz Amparo Ospina M, Diana \\
\hline
\end{tabular}




\begin{tabular}{|c|c|c|c|}
\hline & Curso & $\begin{array}{l}\text { proyecto piloto para la cria de caracol } \\
\text { terrestre comestible }\end{array}$ & Marcela Moreno O. \\
\hline 2007 & $\begin{array}{l}\text { Trabalho de Conclusão de } \\
\text { Curso }\end{array}$ & $\begin{array}{l}\text { Centro de Acopio, uma estratégia para } \\
\text { competir em el mercado francês com } \\
\text { carne de caracol }\end{array}$ & $\begin{array}{l}\text { Oscar Garcia Monje, Alfredo } \\
\text { Guitierrez }\end{array}$ \\
\hline 2007 & $\begin{array}{l}\text { Trabalho de Conclusão de } \\
\text { Curso }\end{array}$ & $\begin{array}{l}\text { Manejo controlado de la temperatura y } \\
\text { humedad em caracoles de tierra de la } \\
\text { espécie Helix Aspersa em el município } \\
\text { de Fusagasuga (Cundinamarca) }\end{array}$ & Rocio del Pilar Jimenez \\
\hline 2007 & $\begin{array}{l}\text { Monografia de Pos- } \\
\text { graduação }\end{array}$ & $\begin{array}{l}\text { Caracoleta S.A. Protocolo plan de } \\
\text { negocios }\end{array}$ & $\begin{array}{l}\text { Juan Fernando Mejía Quintero, } \\
\text { Pulo Cesar Jimenez Molina, } \\
\text { Sandra Patricia Bedoya } \\
\text { Marulanda }\end{array}$ \\
\hline 2008 & Artigo Científico & $\begin{array}{l}\text { Efecto de la densidade poblacional em } \\
\text { la productividad de caracoles } \\
\text { (Helixaspersa) en un sistema a cielo } \\
\text { abierto alimentados con acelga y } \\
\text { suplemento alimentario balanceado }\end{array}$ & $\begin{array}{l}\text { Olga Gonzalez, Gladys Pérez } \\
\text { Camargo, Macarena Membiela, } \\
\text { Diana Frezza, Norberto } \\
\text { Bartolini, Carlos Vieites }\end{array}$ \\
\hline 2008 & $\begin{array}{l}\text { Trabalho de Conclusão de } \\
\text { Curso }\end{array}$ & $\begin{array}{l}\text { Estúdio de mercado para la exportacion } \\
\text { de caracol "Helixaspersa" a España }\end{array}$ & $\begin{array}{l}\text { Marcela AlagunaIgua, Rodrigo } \\
\text { Arturo Amador Sandoval }\end{array}$ \\
\hline 2008 & $\begin{array}{l}\text { Monografia de } \\
\text { Especialização }\end{array}$ & $\begin{array}{l}\text { Plan de negocios. Cria y } \\
\text { comercializacion de caracoles atravez de } \\
\text { la técnica de helicicultura }\end{array}$ & $\begin{array}{l}\text { Juan David Mejia, Lorena } \\
\text { Garcia, Juan Malagón, Oscar } \\
\text { Eslava }\end{array}$ \\
\hline 2008 & Documento do Governo & Decreto 4064 & $\begin{array}{l}\text { Regula os requisitos e } \\
\text { procedimentos ambientais e } \\
\text { fins comerciais de } \\
\text { espécimes das espécies } \\
\text { Helix aspersa. }\end{array}$ \\
\hline 2008 & Documento do Governo & Decreto 2490 & Requerimentos sanitarios \\
\hline 2008 & $\begin{array}{l}\text { Documento do } \\
\text { ICONTEC }\end{array}$ & NTC 5603 & $\begin{array}{l}\text { Norma Técnica Colombiana } \\
\text { ICONTEC }\end{array}$ \\
\hline 2009 & Resolução & $\begin{array}{l}\text { Instituto Colombiano Agripecuaario } \\
\text { (ICA) }\end{array}$ & $\begin{array}{l}\text { Gerente general del Instituto } \\
\text { Colombiano Agripecuaario }\end{array}$ \\
\hline 2010 & $\begin{array}{l}\text { Monografia de } \\
\text { Especialização }\end{array}$ & $\begin{array}{l}\text { Helicicultura: Aspectos controvertidos } \\
\text { de su valuación en el impuesto a las } \\
\text { ganancias }\end{array}$ & Dra. Denise GiseleArietti \\
\hline 2010 & $\begin{array}{l}\text { Monografia Tecnologia em } \\
\text { Produção animal }\end{array}$ & $\begin{array}{l}\text { PDET para la cria y comercializacion de } \\
\text { caracoles (Heliaspersamuller) omo } \\
\text { alternativa de interés ecológico } \\
\text { alimenticio y comercial en el municipio } \\
\text { de Moniquirá- Boyacá }\end{array}$ & $\begin{array}{l}\text { Nora Raquel Hernandez } \\
\text { Medina, Lizy Carolina } \\
\text { Rodriguez Villamil }\end{array}$ \\
\hline 2010 & $\begin{array}{l}\text { Trabalho de Conclusão de } \\
\text { Curso }\end{array}$ & $\begin{array}{l}\text { Creacion y puesta em marcha de uma } \\
\text { empresa de cultivo de caracoles para la } \\
\text { obtención de baba de caracol }\end{array}$ & $\begin{array}{l}\text { Sandra Milena Arrieta Gomez, } \\
\text { Greicy Andrea } \\
\text { EstupiñanButista }\end{array}$ \\
\hline 2010 & Documento do Governo & $\begin{array}{l}\text { Decreto } 1220 / 2005 \text { (revocado pelo } \\
\text { artigo } 52 \text { Decreto Nacional } 2820 /\end{array}$ & $\begin{array}{l}\text { Regulamenta o título VIII da } \\
\text { lei } 99 \text { de } 1993 \text { sobre licenças } \\
\text { ambientais. }\end{array}$ \\
\hline 2010 & Documento do ICA & Resolución ICA 1464 & $\begin{array}{l}\text { Requerimentos para o } \\
\text { registro e condições } \\
\text { sanitárias para prédios } \\
\text { produtores do caracol }\end{array}$ \\
\hline 2011 & Artigo Científico & Quem tem medo do caracol? & Mauricio Aquilo \\
\hline 2011 & Artigo Técnico & $\begin{array}{l}\text { Encadenamiento de la productividad } \\
\text { helicicola en el departamento de } \\
\text { Cundinamarca -Colombia }\end{array}$ & $\begin{array}{l}\text { Luis Alejandro } \\
\text { MartinezRodriguez, Roberto } \\
\text { Mauricio Giraldo Perez, } \\
\text { Miguel Cortes Madrigal, Jesus } \\
\text { Hernando RamirezPaez }\end{array}$ \\
\hline
\end{tabular}




\begin{tabular}{|l|l|l|l|}
\hline 2012 & $\begin{array}{l}\text { Monografia em } \\
\text { Licenciatura em } \\
\text { Administração }\end{array}$ & $\begin{array}{l}\text { Plan de Negocio: cría de caracoles em } \\
\text { cautiverio }\end{array}$ & Ana Clara PerellóHinojosa \\
\hline 2013 & Trabalho de Conclusão de & $\begin{array}{l}\text { Comercialización de caracoles terrestres } \\
\text { comestibles en pro de la creación de una } \\
\text { empresa exportadora }\end{array}$ & $\begin{array}{l}\text { Jaime Alberto León Torres, } \\
\text { Jhoan Camilo Niño }\end{array}$ \\
\hline 2014 & $\begin{array}{l}\text { Monografia de } \\
\text { Especialização }\end{array}$ & $\begin{array}{l}\text { Plan de negocios para exportación de } \\
\text { carne de caracol desde Colombia }\end{array}$ & $\begin{array}{l}\text { Carolina Perdomo Pinzon, Luis } \\
\text { Alberto Baracaldo, Natalia } \\
\text { Tolosa Ardila }\end{array}$ \\
\hline 2014 & Artigo Científico & $\begin{array}{l}\text { La helicicultura em Argentina: uma } \\
\text { aproximacion desde el enfoque de } \\
\text { sistemas blandos }\end{array}$ & $\begin{array}{l}\text { Gelabert, C, de Bargas, S, } \\
\text { Rositano, F, Gonzalez, O }\end{array}$ \\
\hline 2014 & Documento do Governo & $\begin{array}{l}\text { Decreto 2820/2010 } \\
\text { (revocadopeloDecreto 2041) }\end{array}$ & Licenças ambientais \\
\hline 2015 & Nota da Imprensa & $\begin{array}{l}\text { Convenio con la asociacion nacional de } \\
\text { cria y engorde del caracol }\end{array}$ & $\begin{array}{l}\text { Ministerio de Agricultura, } \\
\text { alimentacion y medio ambiente }\end{array}$ \\
\hline 2015 & Arquivos da ANLA (15) & $\begin{array}{l}\text { Solicitudes de licenças ambientais dos } \\
\text { empreendimentos }\end{array}$ & ANLA regulamenta o \\
\hline 2015 & Documentos do DANE & $\begin{array}{l}\text { Dados de Exportaciones e } \\
\text { Importaciones }\end{array}$ & $\begin{array}{l}\text { Dados de Exportaciones e } \\
\text { Importaciones }\end{array}$ \\
\hline 2015 & DocumentosProexport & DANE \\
\hline
\end{tabular}

Fonte: elaborado pela autora

Foi aplicado o método de manifestação livre mediante um roteiro de afirmativas (Apêndice A), com escalas de concordância tipo Likert aos especialistas em produção e comercialização agrícola e associativismo rural que envolve esta atividade, bem como a outros integrantes de interesse da cadeia de produção da helicicultura colombiana. Estas entrevistas foram aplicadas a alguns dos helicicultores que ainda têm seu cultivo e outros que o encerraram; isso com o fim de conhecer aspectos relevantes a nível organizacional e institucional do presente e do passado. Entrevistou-se ainda o Diretor da Associação Asocohelix e o representante do grupo Helix del Sur Colombia os quais forneceram dados importantes para a pesquisa, como informações sobre as redes de helicicultores na Colômbia.

O roteiro proporcionou 40 afirmativas acompanhadas de dois quadros de respostas correspondente para cada ano de avaliação 2003 - 2013. As afirmativas buscavam a concordância ou discordância do entrevistado, a serem respondidas mediante uma Escala do Tipo Likert de cinco pontos (1 a 5) sendo 1 (totalmente em desacordo) e 5 (totalmente de acordo)(Quadro 6). As perguntas foram agrupadas por itens de avaliação de acordo as variáveis encontradas para analise, apresentadas na seguinte sessão. Estes itens foram Legislação, comércio e produção associada, estrutura, gestão e assistência técnica, rede de helicicultores e unidade produtiva. Estas foram aplicadas a um grupo de 20 pessoas 
especialistas envolvidos nesta atividade, entre elas, helicicultores, associações e instituições relacionadas. As entrevistas foram realizadas na cidade de Bogotá por ser a capital da Colômbia e onde está situada a principal sede das instituições relacionadas ao setor e, além disso, possui a maior quantidade de empreendimentos neste campo. Outras entrevistas foram feitas na cidade de Popayán. Por estes meios, procurou-se entender e avaliar os elementos dos contextos organizacionais e institucionais que determinaram a produção de caracol por helicicultores na Colômbia.

\begin{tabular}{|l|l|}
\multicolumn{2}{|c|}{ Quadro 6. Pontos de avaliação } \\
\hline 1 & Totalmente em desacordo \\
\hline 2 & Em desacordo \\
\hline 3 & Nem de acordo, nem desacordo \\
\hline 4 & De acordo \\
\hline 5 & Totalmente de acordo \\
\hline
\end{tabular}

Fonte: elaborado pela autora

\subsection{Variáveis de pesquisa}

As variáveis de pesquisa analisadas para o alcance dos objetivos deste estudo estão apresentadas na Figura 14. Foram separadas como Variáveis relacionadas ao Ambiente Externo e Variáveis relacionadas ao Ambiente Interno.

Entre as Variáveis relacionadas ao Ambiente Externo, subdividiu-se entre aquelas que dizem respeito à legislação (referente à Helicicultura); Estrutura e Gestão da Produção (relacionados à Helicicultura) e aspectos relacionados ao Bioma e sua aptidão à produção de caracóis de terra.

As Variáveis relacionadas ao Ambiente Interno das organizações relacionadas à Helicicultura são as Redes e Ação Coletiva (essencialmente as associações de produtores) e a Unidade Produtiva.

Todas as variáveis (descritas a seguir) relacionadas a estes parâmetros foram apreciadas em entrevistas realizadas com os agentes relacionados ao escopo de produção organizacional e institucional que envolve a Helicicultura na Colômbia. 
Figura 14- As variáveis analisadas

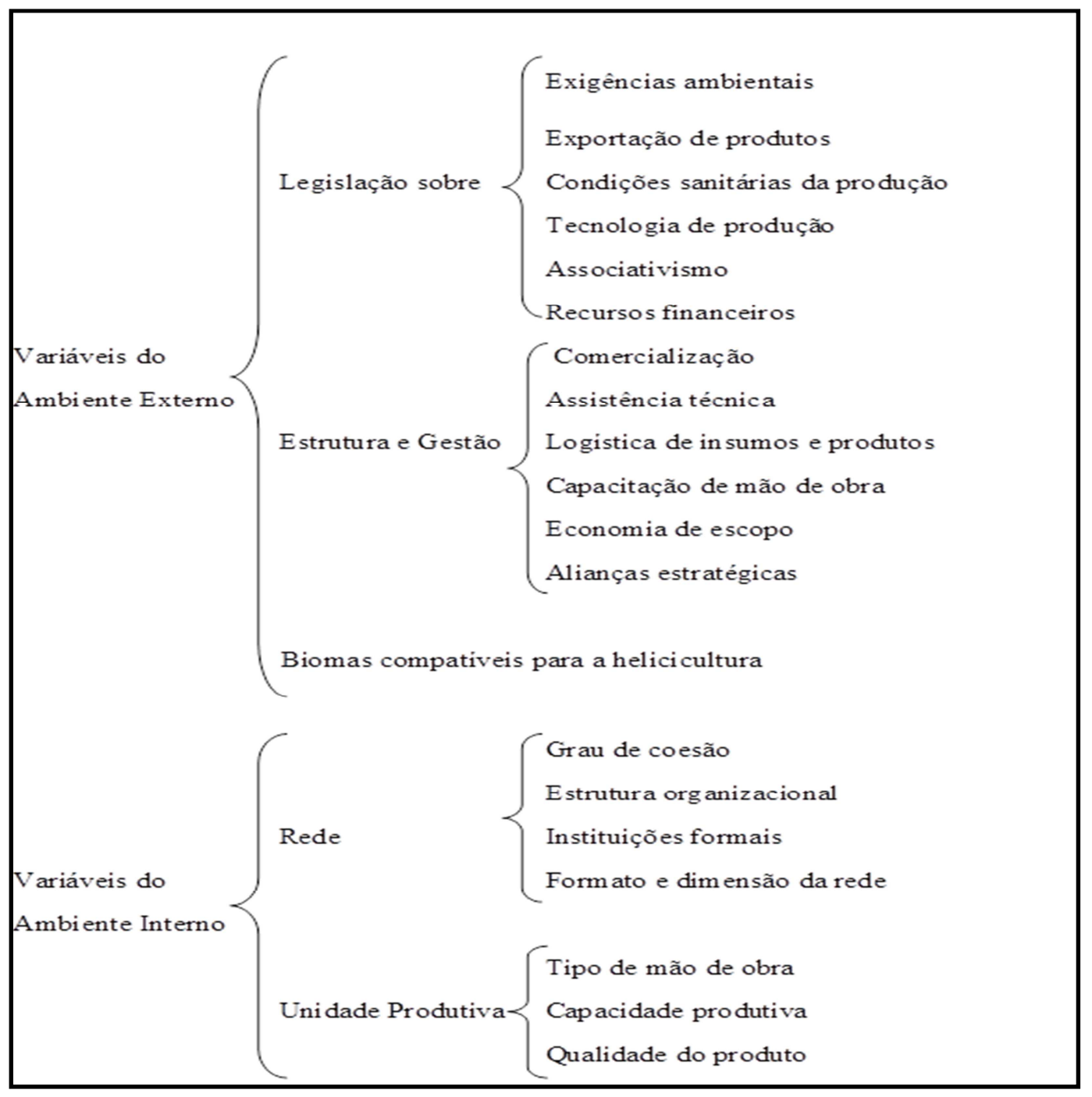

Fonte: elaborado pela autora

A seguir, são apresentadas e descritas de forma detalhada e esquemática as variáveis estudadas.

\subsubsection{Variáveis do ambiente externo}

\section{Legislação}

Meio Ambiente: envolve as leis e regulamentos que se devem acatar na produção de caracol sem prejudicar o meio ambiente.

> Exportação de produtos: regulamentação e condições para exportar os caracóis, segundo os parâmetros dos países envolvidos no processo. 
> Condições sanitárias de produção: avaliar as condições necessárias para a produção e comercialização dos produtos.

Tecnologia de produção: estimar as ferramentas, procedimentos e processos requeridos e permitidos para desenvolver esta atividade, e garantir aos produtores uma cultura de alta qualidade.

$>$ Associativismo: condições de se poderem associar entre produtores, os regulamentos das associações.

$>$ Recursos financeiros: avaliar se existem linhas de crédito que apoiam o empreendimento, neste caso, para cultivo do caracol.

\section{Estrutura e Gestão}

Comercialização: avaliar as atividades que envolvem o processo do intercâmbio de produtos em outros mercados.

> Assistência Técnica: conhecer se existem pessoas capacitadas para assessorar tecnicamente os produtores e ajudar na obtenção de um produto de melhor qualidade.

$>$ Logística de produtos e insumos: reconhecer a logística da aquisição dos insumos, a relação com os fornecedores e a qualidade dos mesmos.

$>$ Capacitação de mão de obra: avaliar se os produtores estão recebendo as capacitações, seminários, palestras que permitam ter uma atualização sobre a produção e comercialização.

> Economia de escopo: para os produtores é importante trabalhar conjuntamente para alcançar grandes mercados, saber se o coletivismo está ajudando a desenvolver esta atividade.

Alianças Estratégicas: saber se as associações e os produtores têm relações comerciais com outras empresas que permitam unir esforços e crescer econômica e comercialmente.

Biomas compatíveis para a helicicultura: apresentar o meio ambiente propício para desenvolver esta atividade e as regiões aptas para o crescimento dos caracóis. 


\subsubsection{Variáveis do ambiente interno}

\section{Rede}

Grau de coesão: a estrutura da associação permite ter um alto grau de coesão entre a rede, e verificar se logram alcançar os objetivos.

Estrutura organizacional: avaliar como está conformada a associação, a forma de se estruturar, processos e procedimentos, as regras, os perfis dos profissionais que influem nos objetivos da organização e assim operar no mercado.

$>$ Instituições formais: conhecer as instituições aliadas aos projetos da helicicultura e a influência que têm para desenvolverem a atividade.

$>$ Formato e dimensão da rede: apresentar a forma como esta conformada a rede de associações e produtores da helicicultura.

\section{Unidade produtiva}

Tipo de mão de obra: conhecer o tipo de trabalhadores que realizam os trabalhos no campo e as famílias envolvidas nesta atividade.

$>$ Capacidade produtiva: avaliar a capacidade da produção de caracol, a qualidade , a extensão e o aproveitamento das terras.

Qualidade do produto: conhecer a manutenção dos cultivos e o manejo na produção e comercialização.

\subsection{Análises dos dados}

O nível institucional foi preciso consultar especialistas sobre o tema, apresentados no; entre eles, trabalhadores do Ministério do Meio Ambiente e do Ministério de Agricultura com a finalidade de conhecer a regulamentação que rege a helicicultura e de manter as melhores condições de preservação do meio ambiente, referente aos diferentes cultivos e atividades que possam prejudicar o meio ambiente e, portanto, aos seres viventes. Para análise da parte ambiental, foi consultada a Autoridade Nacional de Licenças Ambientais (ANLA) encarregada das análises de aprovação das licenças ambientais, organismo independente do Ministério de Meio Ambiente. Também foi preciso consultar as Corporações Autônomas Regionais de Cundinamarca e Cauca, encarregadas do seguimento dos locais de produção 
com licenças ambientais outorgadas. Outras pessoas importantes para a análise foram os representantes do ICA, que são instituições que apoiam ao Ministério do Meio Ambiente, a preservação do meio ambiente e da saúde humana. O ICONTEC, entidade encarregada do controle da qualidade do produto e que estabelece as normas que os helicicultores devem ter presente para vender. As Unidades Municipais de Assistência Técnica (UMATAS), que forneceram informações das técnicas e tecnologias utilizadas na Colômbia para a produção, processos de apoio aos helicicultores e da qualidade do produto também foram entrevistadas. Sobre as linhas de crédito e apoios, foi entrevistado um funcionário do Banco Agrário da Colômbia.

Por último, foi preciso consultar dados nas Câmaras de Comércio das cidades de Popayán e Bogota, DANE e PROCOLOMBIA, para obter dados de comercialização e legalidade dos locais produtores (Quadro 7). Foi analisada a legislação destas instituições relacionadas à conservação do meio ambiente.

Quadro 7. Relação de especialistas entrevistados

\begin{tabular}{|c|c|}
\hline NOME & CARGO \\
\hline Ministério de Agricultura & Funcionário \\
\hline Ministério de Meio Ambiente & Atenção ao Cliente \\
\hline Autoridade Nacional de Licenças Ambientais & $\begin{array}{l}\text { Coordenador do Grupo de } \\
\text { Atenção ao Cidadão }\end{array}$ \\
\hline Corporação Regional de Cundinamarca & Advogado CAR \\
\hline Corporação Regional de Cauca & Atenção Licenças Ambientais \\
\hline Instituto Colombiano Agropecuário & Direção técnica de sanidade \\
\hline $\begin{array}{l}\text { Instituto Colombiano de Normas Técnicas e } \\
\text { certificación }\end{array}$ & $\begin{array}{l}\text { Técnica de lotes e muestra } \\
\text { ICONTEC }\end{array}$ \\
\hline $\begin{array}{l}\text { Departamento Administrativo Nacional de } \\
\text { Estatísticas }\end{array}$ & Atenção ao Cliente \\
\hline $\begin{array}{l}\text { Departamento Administrativo Nacional de } \\
\text { Estatísticas de Popayán }\end{array}$ & Atenção ao Cliente \\
\hline Procolombia & $\begin{array}{l}\text { Assessor do Departamento de } \\
\text { Cauca }\end{array}$ \\
\hline Umata & Contratantes \\
\hline Banco Agrário de Colômbia & Atenção ao cliente \\
\hline Helix del Sur Colômbia & Gerente \\
\hline Cultivo Cajica & Gerente \\
\hline Asocohelix & Diretor \\
\hline Carcoles la Playa & Produtor Familiar \\
\hline Cohecol & Gerente \\
\hline Criadero de caracoles la Juliana & Proprietário \\
\hline A Comer caracol & Gerente \\
\hline
\end{tabular}

Fonte: elaborado pela autora 
Os achados das respostas obtidas permitiu estabelecer uma análise crítica sobre aqueles parâmetros organizacionais e institucionais envolvidos nesta atividade, os aspectos que levaram ao decréscimo da produção de caracol na Colômbia, os conhecimentos das regulamentações que regem esta atividade e a aferição das informações colhidas em trabalhos anteriores.

Para a análise, utilizou-se a elaboração de um quadro comparativo de resultados a partir da inserção dos dados em uma planilha elaborada pelo Software Microsoft Excel Office 15, donde se analisou:

1. A pontuação média das respostas dos entrevistados sobre cada questão e sua correspondência em uma escala apresentada no Quadro 8;

Quadro 8- Escala da meia das respostas

\begin{tabular}{|c|c|}
\hline 1,0 a 2,0 & Baixa \\
\hline 2,1 a 3,9 & Média \\
\hline 4,0 a 5,0 & Alta \\
\hline
\end{tabular}

Fonte: elaborado pela autora

2. A variação da pontuação média das respostas dos entrevistados sobre cada questão entre 2003 e 2013;

3. A variação percentual da pontuação média das respostas dos entrevistados sobre cada questão entre 2003 e 2013 e sua correspondência em uma escala apresentada no Quadro 9 que compara os dois períodos a partir de 2003 e;

Quadro 9- escala de correspondência de comparação

\begin{tabular}{|c|l|}
\hline Mais de $10 \%$ & Significativamente Melhor \\
\hline De 0,1 a $10 \%$ & Pouco Melhor \\
\hline $0 \%$ & Não Mudou \\
\hline De $-0,1$ a $-10 \%$ & Pouco Pior \\
\hline Menos de $-10 \%$ & Significativamente Pior \\
\hline
\end{tabular}

Fonte: elaborado pela autora

4. Comparação entre as variáveis analisadas, indicando se há e quais eventualmente poderão ter sido determinantes ou suficientes para a variação do desempenho da atividade na Colômbia, considerando o efetivo de produtores associados no País. 


\section{RESULTADOS}

Para a apresentação dos resultados, foi analisada de forma documental a legislação colombiana no período de 1993 até 2014 para conhecer as leis, decretos, resoluções que protegem o meio ambiente a flora e fauna. Como toda atividade que envolva o consumo humano precisa ter regras para garantir à qualidade do alimento, sem prejudicar a saúde dos consumidores, a helicicultura está rodeada de regulamentações, apresentadas no Quadro 10.

Quadro 10- Regulamentação da helicicultura colombiana 1993 - 2010

\begin{tabular}{|c|c|c|}
\hline Regulamentação & Tema & Atores \\
\hline $\begin{array}{l}\text { Lei } 99 \text {, de } 22 \text { de } \\
\text { dezembro de } 1993\end{array}$ & $\begin{array}{l}\text { Gestão ambiental nacional, criação do } \\
\text { Ministério do Meio Ambiente, reordena-se o } \\
\text { setor público responsável da gestão e } \\
\text { conservação do meio ambiente e os recursos } \\
\text { naturais renováveis. É organizado o Sistema } \\
\text { Nacional Ambiental SINA, e outras } \\
\text { disposições. }\end{array}$ & $\begin{array}{l}\text { Congresso da República de } \\
\text { Colômbia; Inderena }{ }^{3} \text {; Grupos } \\
\text { ambientais e Universidades }\end{array}$ \\
\hline Lei 165/1994 & $\begin{array}{l}\text { Convenio das Nações Unidas pela diversidade } \\
\text { biológica. } \\
\text { Publicado no Diário Oficial No. } 41589\end{array}$ & $\begin{array}{l}\text { Congresso da República da } \\
\text { Colômbia; Ministério de Meio } \\
\text { Ambiente; Ministério de } \\
\text { Agricultura; Corporações } \\
\text { autônomas regionais e entidades } \\
\text { territoriais }\end{array}$ \\
\hline Lei $611 / 2000$ & $\begin{array}{l}\text { Diário Oficial No. } 44.144 \text {, de } 29 \text { de agosto } \\
\text { de } 2000 \text {, pelo qual estabelece normas para o } \\
\text { manejo sustentável de espécies de fauna } \\
\text { Silvestre e aquática. }\end{array}$ & $\begin{array}{l}\text { Ministério de Meio Ambiente; } \\
\text { Instituto Colombiano de } \\
\text { Agricultura; Corporações } \\
\text { autônomas regionais e entidades } \\
\text { territoriais }\end{array}$ \\
\hline $\begin{array}{l}\text { Resolução 0438, de } \\
23 \text { de maio de } 2001\end{array}$ & $\begin{array}{l}\text { Estabelece o salvo-conduto único nacional } \\
\text { para a mobilização de espécies da diversidade } \\
\text { biológica }\end{array}$ & Ministério do Meio Ambiente \\
\hline $\begin{array}{l}\text { Decreto } 1220 / 2005 \\
\text { (revocado pelo } \\
\text { artigo } 52 \text { decreto } \\
\text { Nacional } 2820 / \\
\text { 2010) }\end{array}$ & $\begin{array}{l}\text { Regulamenta o título VIII da lei } 99 \text { de } 1993 \\
\text { sobre licenças ambientais. }\end{array}$ & \\
\hline $\begin{array}{l}\text { Lei } 1011 \text {, de } 23 \text { de } \\
\text { janeiro de } 2006\end{array}$ & $\begin{array}{l}\text { Pela qual autoriza e regulamenta atividade da } \\
\text { helicicultura e dita outras considerações }\end{array}$ & $\begin{array}{l}\text { Congresso da República da } \\
\text { Colômbia }\end{array}$ \\
\hline
\end{tabular}

${ }^{3}$ Inderena: Instituto Nacional de Recursos naturais renováveis e do ambiente, existiu há 20 anos, este foi substituído pelas Corporações Regionais dos departamentos. 


\begin{tabular}{|c|c|c|}
\hline $\begin{array}{l}\text { Decreto } 4064 \text {, de } 5 \\
\text { de agosto de } 2008\end{array}$ & $\begin{array}{l}\text { Regulamenta parcialmente a lei } 1011 \text { de } \\
2006 \text { e adotam outras disposições. } \\
\text { Regula os requisitos e procedimentos } \\
\text { ambientais e fins comerciais de espécimes } \\
\text { das espécies Helix aspersa. }\end{array}$ & Presidente Álvaro Uribe Velez \\
\hline Decreto 2490/2008 & $\begin{array}{l}\text { Estabelece o regulamento técnico sobre os } \\
\text { requerimentos sanitários que devem cumprir } \\
\text { os estabelecimentos dedicados ao processo, } \\
\text { embalagem, transporte, importação, } \\
\text { exportação e comercialização de caracóis } \\
\text { com destino ao consumo humano. } \\
\text { Publicado no diário oficial No. } \\
47045\end{array}$ & Ministério da Proteção social \\
\hline NTC 5603/2008 & $\begin{array}{l}\text { Norma Técnica Colombiana ICONTEC } \\
\text { Cultivo de caracol terrestre. Esta norma } \\
\text { estabelece os requisitos mínimos para } \\
\text { instalação e operação zoocriadores de } \\
\text { caracol de terra do gênero Helix. }\end{array}$ & $\begin{array}{l}\text { Associações de helicicultores } \\
\text { Importadores de carne de caracol } \\
\text { Instituto Colombiano de } \\
\text { Agricultura e Secretaria de Saúde }\end{array}$ \\
\hline $\begin{array}{l}\text { Decreto 2820/2010 } \\
\text { (revocado pelo } \\
\text { decreto } 2041 \text { de } \\
\text { 2014) }\end{array}$ & $\begin{array}{l}\text { Regulamenta o título VIII da lei } 99 \text { de } 1993 \\
\text { sobre licenças ambientais }\end{array}$ & \\
\hline $\begin{array}{l}\text { Resolução ICA } \\
1464 / 2010\end{array}$ & $\begin{array}{l}\text { Estabelece os requerimentos para o registro } \\
\text { e condições sanitárias para prédios } \\
\text { produtores do caracol Helix Aspersa e } \\
\text { outras disposições. } \\
\quad \text { Diário Oficial: } 47694 \text { de } 2010\end{array}$ & $\begin{array}{l}\text { Instituto Colombiano de } \\
\text { Agricultura }\end{array}$ \\
\hline $\begin{array}{l}\text { Decreto } 2041 \text {, de } 15 \\
\text { de outubro de } 2014\end{array}$ & $\begin{array}{l}\text { Pelo qual regulamenta o titulo VIII da lei } 99 \\
\text { de } 1993 \\
\text { Publicado no Diário Oficial No. } 49305 \text { de } \\
2014\end{array}$ & $\begin{array}{l}\text { Juan Manuel Santos (Presidente da } \\
\text { República), Gabriel Vallejo López } \\
\text { (Ministro de ambiente e } \\
\text { Desenvolvimento Sustentável). }\end{array}$ \\
\hline
\end{tabular}

Fonte: elaborado pela autora

O período em análise no Quadro 5 é entre 1993 e 2014. É possível conferir que em 21 (vinte um) anos se promulgaram 12 (doze) regulamentações, 4 (quatro) leis, 5(cinco) decretos,2 (duas) resoluções e 1(uma) norma técnica. Diferentes níveis de governo e do legislativo colombiano se envolveram com a promulgação da normatividade e busca pela institucionalização da helicicultura no país. Também se pode observar que tive anos que a regulamentação não apresentou mudanças.

A primeira foi a Lei Geral Ambiental 99 de 1993, foi apresentada pelo senador Anatolio Quira com o objetivo de garantir a gestão ambiental nacional, ou seja, garantir o 
aproveitamento dos recursos naturais sem danificar a natureza e o bem estar dos cidadãos. Esta lei promulga a criação do Ministério do Meio ambiente e o Sistema Nacional Ambiental (SINA), para proteger a biodiversidade nacional. (COLÔMBIA, Ministério de Medio Ambiente, 2015). Sendo assim, o Ministério do Meio Ambiente representa o órgão condutor da gestão do ambiente e dos recursos naturais renováveis, responsável por promover a relação entre o homem e a natureza baseada no respeito, definir as políticas e regulamentações que serão objeto de recuperação, conservação, proteção, planejamento, gestão, uso e desenvolvimento de recursos naturais renováveis e o meio ambiente da nação, para garantir o desenvolvimento sustentável.

A respeito desta Lei, o artigo 4 apresenta o Sistema Nacional Ambiental (SINA) como: "a série de orientações, normas, atividades, recursos, programas e instituições que permitem a aplicação dos princípios gerais contidos na presente lei ambiental" (COLÔMBIA, Ministério de Medio Ambiente, 2015).

Entre elas, cabe destacar a responsabilidade do Estado para com a organização e o funcionamento do sistema, que deverá ser composto de:

Entidades estaduais responsáveis pela política ambiental e de ação delineado na lei, a comunidade e organizações não governamentais interessadas nas questões ambientais, ás fontes e os recursos financeiros para a gestão e recuperação do meio ambiente, as entidades públicas, privadas ou mistas envolvidas na produção, investigação científica e desenvolvimento tecnológico no domínio do ambiente. (COLÔMBIA, Ministério de Medio Ambiente, 2015, sp)

Esta lei é aplicada para todos os campos de produção, incluindo a helicicultura, já que esta se desenvolve em campos naturais, ou seja, envolve o meio ambiente. Segundo Zambrano (2015) para o estabelecimento de zoocriadores para a produção de caracol é preciso obter uma licença ambiental contida no Decreto 1.220 de 2005 (revocado), pelo Decreto 2.820 de 2010 (revogado), e finalmente pelo Artigo 53 do Decreto 2.041 de 2014 que regulamenta o Título VIII da presente Lei, o qual expõe:

As execuções de obras, o estabelecimento de indústrias ou desenvolvimento de qualquer atividade, de acordo com a lei e os regulamentos, podem causar grave deterioração dos recursos naturais renováveis ou para o ambiente ou introduzir modificações consideráveis ou notórias à paisagem exigem uma Licença Ambiental. [...] na emissão de licenças ambientais e para a concessão de autorizações terem-se presente as disposições relativas ao meio ambiente e controle, preservação e proteção do patrimônio ecológico, emitidos pelas autoridades locais na respectiva jurisdiçã.(COLÔMBIA, Ministério de Medio Ambiente, 2015, sp). 
Assim, segundo dados apresentados por Delgado (2009), este ponto da Lei proíbe a importação do caracol Helix aspersa, por risco ambiental, baseado no Artigo 1, n. 6, que depara o seguinte:

\begin{abstract}
A formulação de políticas ambientais levarem em conta o resultado do processo pesquisa científica. No entanto, aplicam-se as autoridades ambientais e indivíduos o princípio da precaução, segundo o qual, quando houver perigo de dano grave e irreversível, a falta de certeza científica absoluta não será utilizada como razão para postergar medidas eficazes para evitar a degradação ambiental. (COLÔMBIA, Alcaldia Mayor de Bogotá, 2015, sp).
\end{abstract}

Igua e Sandoval (2008) argumentam que o Titulo VIII desta Lei exige a importação da semente (pé de cria) de países com empresas helicicultoras aprovadas como Argentina, Chile, Peru, Espanha, entre outros. Estas concepções já eram apresentadas nos antigos decretos, e ainda estão presentes ao novo decreto acrescidas de algumas modificações, das quais: tempo de análise de documentos, visitas ao lugar para conhecer as instalações onde será feito o projeto, novos formatos e requerimentos para adquirir a licença ambiental e os termos de entrega das licenças (COLÔMBIA, Alcaldia Mayor de Bogotá, 2015, sp).

A Lei 99 de 1993 vem sustentada pelo convênio das Nações Unidas sobre diversidade biológica para Colômbia, firmado no Rio de Janeiro em 5 (cinco) de junho de 1992, por meio da Lei 165 de 1995. Para o cumprimento do acordo, as suas disposições relevantes são:

[...] a conservação da diversidade biológica, a utilização sustentável dos seus componentes e a partilha justa e equitativa dos benefícios decorrentes da utilização dos recursos genéticos, mediante, nomeadamente, o acesso adequado aos recursos genéticos ea transferência adequada de tecnologias pertinentes, levando em conta todos os direitos sobre esses recursos e tecnologias, bem como mediante um financiamento apropriado (COLÔMBIA, Ministério de Medio Ambiente, 2015, sp).

Esta lei permite que as partes contratantes possam trabalhar de forma individual, mas com uma sinergia entre todos para garantir que a natureza não seja prejudicada, e contribua ao desenvolvimento das regiões. Permite criar políticas públicas que garantam que os Estados façam uma correta conservação da diversidade biológica e o uso sustentável dos recursos. (COLÔMBIA, Ministério de Medio Ambiente, 2015, sp).

Segundo o Ministério do Meio Ambiente, para o transporte de espécies de flora e a fauna, há necessidade de que se garanta seu adequado tratamento e é preciso que se faça o trâmite para obter a permissão de transporte. Este vem definido pela Resolução 438 de 2001 a qual define os termos para a mobilização de espécies da diversidade biológica. Segundo a Resolução, é o documento que expede a autoridade ambiental e autoriza o transporte de 
espécimes da diversidade biológica a nível nacional. Este é determinado por um período de tempo e tem vencimento. O documento será expedido de acordo com os documentos apresentados, sob os parâmetros que sejam requeridos. (COLÔMBIA, Alcaldía Mayor de Bogotá, 2015, sp).

Para regulamentar o cultivo de caracol foi preciso criar uma lei para garantir ótimos processos no cultivo: a Lei 1.011 de 2006, que permite:

[...] a exploração de caracol de gênero Helix, e regular a atividade do caracol, preservando o meio ambiente e garantir a segurança pública. Para estes fins, as atividades relacionadas com o estabelecimento de reprodução em cativeiro, desde o recolha e seleção de caracol Helix gênero, o estabelecido e adaptado às diferentes regiões serão consideradas exemplares (COLÔMBIA, Instituto Colombiano Agropecuário, 2015, sp).

Nela, estão especificadas as regras que se devem cumprir em relação à política ambiental, plano de manejo ambiental e plano de manejo sanitário. Esta lei vem regulamentada parcialmente pelo Decreto 4.064 de 2008 para a legalização da produção.

Este decreto regulamenta normas e procedimentos ambientais e de saúde animal para a realização de atividades de criação para fins comerciais de espécimes das espécies Helix aspersa encontrados no país, em ciclo fechado, aberto e ciclo combinado (COLÔMBIA, Instituto Colombiano Agropecuário, 2015, sp).

O Decreto 2.490 de 2008 regulamenta os requerimentos sanitários que se devem ser considerados para a embalagem, transporte, importação e exportação dos caracóis. Tem como objeto as normas técnicas sanitárias que os estabelecimentos produtores de caracóis devem cumprir para atender aos processos de embalagem, transporte, venda, importação, exportação e comercialização com destino ao consumo humano, procurando proteger a saúde humana (COLÔMBIA, Instituto Colombiano Agropecuário, 2015, sp).

Segundo Zambrano (2015), nos períodos iniciais da produção de caracol na Colômbia, trabalhou-se o tema com certo desconhecimento, sendo depois legalizada segundo outras espécies animais. Mediante a Lei 1.011 de 2006, autorizou-se a exploração de caracol de terra de gênero Helix com respeito à manutenção dos incubatórios. Esta lei foi regulamentada pelo Decreto 4.064 de 2008 que apresenta os requerimentos e procedimentos ambientais para a realização da atividade. Para o estabelecimento de zoocriadores com fins comerciais é preciso hoje ter uma licença ambiental de acordo com o conteúdo do Decreto 2.041 de 2014 que regulamenta o Título VIII da Lei 99 de 1993 e complementando com os trâmites do Decreto 
2.490 de 2008, expedido pelo Ministério de Proteção Social que estabelece os requisitos sanitários que devem ter os estabelecimentos helicícolas.

Outra lei importante sobre o manejo de fauna silvestre e aquática colombiana é a 611 de 2000 a qual dita disposições sobre o registro dos zoocriadores, disposições sobre as áreas aptas para cria de espécimes, estes não podem ser montados no setor urbano, tem que ter a permissão legal da autoridade representante, neste caso o INCORA, para sua montagem. Tratam dos requerimentos para a montagem, obtenção, identificação e transporte das sementes e por último o controle dos zoocriadores. (COLÔMBIA, Instituto Colombiano Agropecuário, 2015, sp).

Finalmente, os regulamentos do ICA, responsável por exercer ações de sanidade agropecuária e controle técnico das importações, exportações, produção, comercialização e utilização de insumos agrícolas para proteger a produção agrícola nacional e de alimentos e minimizar os riscos ambientais decorrentes da utilização dos mesmos e facilitar o acesso dos produtos nacionais aos mercados internacionais.

A Resolução 1.464 de 2010 estabelece os requerimentos para o registro e condições sanitárias para prédios produtores do caracol Helix aspersa; é concedido um prazo de 6 meses a partir da emissão da presente lei para que aquelas pessoas interessadas em obter o registro sanitário dos locais produtores de caracol Helix aspersa cumpram com as condições requeridas nesta Lei. (COLÔMBIA, Instituto Colombiano Agropecuário, 2015, sp).

Para complementar as regulamentações, a entidade de caráter privado ICONTEC, cuja missão é garantir suporte e desenvolvimento do produtor e proteção ao consumidor, ajuda ao setor governamental e apoia o setor privado do país, na busca de vantagens competitivas nos mercados interno e externo. Com a Norma NTC 5.603, são estabelecidos os requisitos mínimos para instalação e operação dos zoocriadores de caracol de terra do gênero Helix. Segundo Zambrano (2015), o ICONTEC, com a colaboração dos helicicultores elaborou os critérios para a obtenção das Normas de Qualidade ISO 14000.

Continuando com os resultados das manifestações livres serão destacados os achados relativos a cada uma das afirmativas trabalhadas nas entrevistas, apresentando algumas respostas dos entrevistados.

A seguir, na Tabela 7 é apresentada uma planilha-resumo com as médias das apreciações dos entrevistadores e as impressões sobre estas médias, conforme prescrito no método deste estudo, segundo os Quadro 8 e Quadro 9. 
Tabela 7-Resultados da pesquisa: médias e impressões sobre pontuações apresentadas pelos respondentes.

\begin{tabular}{|c|c|c|c|c|c|c|}
\hline \multirow{3}{*}{ LEGISLAÇÕES, COMÉRCIO E PRODUÇÃO } & \multirow{2}{*}{\multicolumn{2}{|c|}{2003}} & \multirow{2}{*}{\multicolumn{2}{|c|}{2013}} & \multirow[b]{3}{*}{ VARIAÇ̃̃o } & \multirow[b]{3}{*}{$\%$} \\
\hline & & & & & & \\
\hline & ESCORE & POSIÇão & ESCORE & POSIÇão & & \\
\hline $\begin{array}{l}\text { La ley } 99 \text {, de diciembre de } 1993 \text {, que trata de la gestión } \\
\text { y conservación del medio ambiente y los recursos } \\
\text { naturales renovables afectó la producción de caracol en } \\
\text { Colombia }\end{array}$ & 1,65 & Baixa & 1,70 & Baixa & 0,05 & $3,0 \%$ \\
\hline $\begin{array}{l}\text { El convenio de las naciones decretado en la ley } 165 \text { de } \\
1994 \text { que protege la diversidad biológica influenció en } \\
\text { la producción de caracol en Colombia }\end{array}$ & 2,05 & Média & 2,00 & Média & $-0,05$ & $-2,4 \%$ \\
\hline $\begin{array}{l}\text { Con la implementación de la ley } 1011 \text { de } 2006 \text { que } \\
\text { reglamenta la actividad de la helicicultura se vieron } \\
\text { afectados los cultivos de caracol en Colombia }\end{array}$ & 3,20 & Média & 3,75 & lédia & 0,55 & $17,2 \%$ \\
\hline $\begin{array}{l}\text { Mediante la ley anteriormente descrita se decretaron la } \\
\text { obtención de licencias ambientales. Este proceso afectó } \\
\text { la producción y comercialización de esta especie en } \\
\text { Colombia }\end{array}$ & 3,45 & ia & 3,65 & lia &, 20 & $5,8 \%$ \\
\hline $\begin{array}{l}\text { Las norma técnicas de calidad afectaron los predios de } \\
\text { los productores de caracol en Colombia }\end{array}$ & 2,45 & Média & 2,55 & Média & 0,10 & $4,1 \%$ \\
\hline $\begin{array}{l}\text { Con la reglamentación que tuvo esta actividad, } \\
\text { disminuyo la exportación e importación de caracol en } \\
\text { Colombia }\end{array}$ & 4,15 & Alta & 3,80 & Média & $-0,35$ & $-8,4 \%$ \\
\hline $\begin{array}{l}\text { Los procesos y procedimientos de exportación son } \\
\text { influencia para las personas generar producción de } \\
\text { caracol }\end{array}$ & 4,10 & & 4,45 & Alta & 35 & $8,5 \%$ \\
\hline $\begin{array}{l}\text { Los requerimientos de los países importadores por } \\
\text { obtener productos de excelente calidad influyen en el } \\
\text { proceso de producción y comercialización de caracol en } \\
\text { Colombia }\end{array}$ & 4,80 & & 00 & Ita & 0 & $4,2 \%$ \\
\hline $\begin{array}{l}\text { La tecnología utilizada para la producción y } \\
\text { manutención de la cría de caracol ha influenciado en los } \\
\text { procesos de crecimiento de esta actividad agrícola }\end{array}$ & 5,00 & & 5,00 & Alta & 0,00 & $0,0 \%$ \\
\hline $\begin{array}{l}\text { Los costos para nueva tecnología influyen en los } \\
\text { análisis de inversión para la producción de caracol en } \\
\text { Colombia }\end{array}$ & 4,60 & A & 4,20 & Alta & $-0,40$ & $-8,7 \%$ \\
\hline $\begin{array}{l}\text { Las legislaciones sobre la helicicultura incentivó la } \\
\text { formación de asociaciones, cooperativas para ayudar al } \\
\text { desarrollo de esta actividad }\end{array}$ & 2,90 & & 2,60 & & $-0,30$ & $10,3 \%$ \\
\hline $\begin{array}{l}\text { La falta de asociaciones consolidadas que apoyen el } \\
\text { desarrollo de esta actividad es un factor determinante de } \\
\text { la producción de caracol en Colombia }\end{array}$ & 4,50 & & 4,20 & Alta & $-0,30$ & $-6,7 \%$ \\
\hline $\begin{array}{l}\text { Para incentivar la producción de caracol se cuentan con } \\
\text { líneas de crédito, préstamos a baja tasa de interés, para } \\
\text { siembra y mantenimiento de la producción }\end{array}$ & 1,35 & Baixa & 1,90 & Baixa & 0,55 & $40,7 \%$ \\
\hline $\begin{array}{l}\text { El transporte (terrestre, aéreo, marítimo) de los } \\
\text { productos requieren de protocolos para poder exportar, } \\
\text { estos protocolos intervienen en la producción de caracol }\end{array}$ & 4,30 & Alta & 4,40 & Alta & 0,10 & $2,3 \%$ \\
\hline $\begin{array}{l}\text { Hacer alianzas estratégicas con otras empresas del } \\
\text { sector ha debilitado la producción de caracol en } \\
\text { Colombia }\end{array}$ & 2,90 & $\mathrm{a}$ & 3,40 & Iédia & 0,50 & $17,2 \%$ \\
\hline $\begin{array}{l}\text { ESTRUTURA, GESTÃO E ASSISTÊNCIA } \\
\text { TÉCNICA. }\end{array}$ & & & & & & \\
\hline $\begin{array}{l}\text { Para toda actividad agrícola es importante tener } \\
\text { asistencia técnica que permita obtener productos de } \\
\text { excelente calidad, la helicicultura posee estas asistencias } \\
\text { técnicas a los predios productores }\end{array}$ & 3,70 & Média & 3,75 & Média & 0,05 & $1,4 \%$ \\
\hline
\end{tabular}




\begin{tabular}{|c|c|c|c|c|c|c|}
\hline $\begin{array}{l}\text { Para obtener un producto de buena calidad es } \\
\text { importante la asistencia técnica por parte de las } \\
\text { instituciones encargadas, este proceso favorece el } \\
\text { desarrollo de la helicicultura en Colombia }\end{array}$ & 4,45 & Alta & 4,45 & Alta & 0,00 & $0,0 \%$ \\
\hline $\begin{array}{l}\text { Para el desarrollo de esta actividad se cuenta con } \\
\text { personal capacitado para apoyar a los helicicultores }\end{array}$ & 2,90 & Média & 2,95 & Média & 0,05 & $1,7 \%$ \\
\hline $\begin{array}{l}\text { Este personal cuenta constantemente con capacitaciones } \\
\text { que permitan desarrollar un trabajo de calidad }\end{array}$ & 3,05 & Média & 3,10 & Média & 0,05 & $1,6 \%$ \\
\hline $\begin{array}{l}\text { Los protocolos de las visitas técnicas (tiempo de la } \\
\text { visita, tiempo entre una visita y otra) influye en el } \\
\text { desarrollo de los predios productores de caracol } \\
\end{array}$ & 3,80 & Média & 4,00 & Média & 0,20 & $5,3 \%$ \\
\hline $\begin{array}{l}\text { Las capacitaciones a los productores por parte de las } \\
\text { instituciones encargadas influyen en el desarrollo de la } \\
\text { actividad helicícola en Colombia }\end{array}$ & 4,05 & Média & 4,30 & Média & 0,25 & $6,2 \%$ \\
\hline $\begin{array}{l}\text { Estas capacitaciones permiten obtener nuevos } \\
\text { conocimientos de técnicas e insumos requeridos, la } \\
\text { adquisición de estos insumos es un factor determinante } \\
\text { en el desarrollo de esta actividad }\end{array}$ & 4,50 & Alta & 4,50 & Alta & 0,00 & $0,0 \%$ \\
\hline $\begin{array}{l}\text { La cantidad de proveedores y la calidad de los insumos } \\
\text { son un determinante para la producción de caracol }\end{array}$ & 4,45 & Alta & 4,15 & Alta & $-0,30$ & $-6,7 \%$ \\
\hline $\begin{array}{l}\text { Los costos de los insumos influencian en el desarrollo } \\
\text { de la helicicultura }\end{array}$ & 4,15 & Alta & 4,00 & Alta & $-0,15$ & $-3,6 \%$ \\
\hline $\begin{array}{l}\text { Las vías de acceso para transporte de productos son } \\
\text { factores que determinan la producción de caracol en } \\
\text { Colombia }\end{array}$ & 3,65 & Média & 3,85 & Média & 0,20 & $5,5 \%$ \\
\hline $\begin{array}{l}\text { El clima, los suelos, temperatura son factores } \\
\text { determinantes de la producción de esta especie en } \\
\text { Colombia }\end{array}$ & 5,00 & Alta & 4,85 & Alta & $-0,15$ & $-3,0 \%$ \\
\hline $\begin{array}{l}\text { La mano de obra calificada permite obtener óptimos } \\
\text { resultados. En Colombia se cuanta con este tipo de } \\
\text { mano de obra capacitada para desarrollar esta actividad }\end{array}$ & 3,60 & Média & 4,25 & Média & 0,65 & $18,1 \%$ \\
\hline $\begin{array}{l}\text { Los procesos de investigación e innovación influencian } \\
\text { en el desarrollo de esta actividad en Colombia }\end{array}$ & 5,00 & Alta & 4,90 & Alta & $-0,10$ & $-2,0 \%$ \\
\hline $\begin{array}{l}\text { Los conflictos sociales, culturales, políticos influyen en } \\
\text { la decisión de invertir en esta actividad }\end{array}$ & 4,80 & Alta & 4,90 & Alta & 0,10 & $2,1 \%$ \\
\hline \multicolumn{7}{|l|}{ REDE E ASSOCIACCÕES DE PRODUTORES } \\
\hline $\begin{array}{l}\text { Una red consolidada de helicicultores contribuye al } \\
\text { crecimiento de la producción de caracol en Colombia }\end{array}$ & 2,90 & Média & 3,30 & Média & 0,40 & $13,8 \%$ \\
\hline $\begin{array}{l}\text { La estructura organizacional de esta red influye en el } \\
\text { proceso de producción de caracol en Colombia }\end{array}$ & 2,40 & Média & 2,40 & Média & 0,00 & $0,0 \%$ \\
\hline $\begin{array}{l}\text { Los procesos y procedimientos adoptados por esta red } \\
\text { contribuirían al desarrollo de la actividad }\end{array}$ & 2,70 & Média & 2,45 & Média & $-0,25$ & $-9,3 \%$ \\
\hline $\begin{array}{l}\text { La relación de esta red con las instituciones que rigen } \\
\text { esta actividad influencia en el desarrollo de la actividad }\end{array}$ & 3,80 & Média & 4,05 & Alta & 0,25 & $6,6 \%$ \\
\hline $\begin{array}{l}\text { La relación y participación de los asociados en la toma } \\
\text { de decisiones dentro de las asociaciones influye en el } \\
\text { desarrollo de la helicicultura en Colombia }\end{array}$ & 4,05 & Média & 3,90 & Média & $-0,15$ & $-3,7 \%$ \\
\hline \multicolumn{7}{|l|}{ UNIDADE DE PRODUÇÃO } \\
\hline $\begin{array}{l}\text { La extensión de tierra de los productores colombianos } \\
\text { son adecuadas para la producción de caracol para } \\
\text { exportar }\end{array}$ & 4,90 & Alta & 4,95 & Alta & 0,05 & $1,0 \%$ \\
\hline $\begin{array}{l}\text { La calidad de estas tierras influencia en el cultivo de } \\
\text { caracol en Colombia }\end{array}$ & 4,20 & Alta & 4,50 & Alta & 0,30 & $7,1 \%$ \\
\hline \begin{tabular}{|l|} 
La capacidad de los recursos (financieros, \\
patrimoniales) que poseen los productores influye en la \\
producción de caracol para poder exportar
\end{tabular} & 3,95 & Média & 4,35 & Alta & 0,40 & $10,1 \%$ \\
\hline $\begin{array}{l}\text { El tipo de mano de obra de su escogencia es el adecuado } \\
\text { para el cultivo de caracol }\end{array}$ & 2,50 & Média & 2,25 & Média & $-0,25$ & $10,0 \%$ \\
\hline
\end{tabular}




\begin{tabular}{|l|c|c|c|c|c|c|}
$\begin{array}{l}\text { Se ejecuta la adecuada capacitación para mejorar la } \\
\text { calidad del producto para el personal de labores } \\
\text { helicícolas }\end{array}$ & 2,20 & Média & 2,20 & Média & 0,00 & $0,0 \%$ \\
\hline $\begin{array}{l}\text { La venta de la producción a terceras personas, no } \\
\text { directamente con las asociaciones influencia en el } \\
\text { proceso de desarrollo de esta actividad }\end{array}$ & 3,30 & Média & 3,50 & Média & 0,20 & $6,1 \%$ \\
\hline
\end{tabular}

Fonte: Dados da pesquisa

\begin{tabular}{|c|c|}
\hline 1,0 a 2,0 & Baixa \\
\hline 2,1 a 3,9 & Média \\
\hline 4,0 a 5,0 & Alta \\
\hline
\end{tabular}

Fonte: elaborada pela autora

\begin{tabular}{|c|l|}
\hline Mais de $10 \%$ & Significativamente Melhor \\
\hline De 0,1 a $10 \%$ & Pouco Melhor \\
\hline $0 \%$ & Não Mudou \\
\hline De $-0,1$ a $-10 \%$ & Pouco Pior \\
\hline Menos de $-10 \%$ & Significativamente Pior \\
\hline
\end{tabular}

Fonte: elaborada pela autora

\subsection{Legislações, Comércio e Produção}

Sobre os aspectos relacionados à Legislação, Comércio e Produção, foram apreciadas 15 afirmações. Os resultados encontrados foram:

As exigências ambientais envolvem leis que protegem o meio ambiente, flora e fauna do país. Na Colômbia existe a Lei 99 de 1993 que trata da conservação do meio ambiente e os recursos naturais. A $\mathbf{1}^{\text {a }}$ afirmativa apresentada demonstrou uma baixa posição, na opinião dos respondentes, ou seja, para eles, tal lei não afetou significativamente a variação na produção helicícolas da Colômbia, nem no período que envolve o ano de 2003, nem em data mais recente, 2013.

Por outro lado, a Lei 165 de 1994, (conjecturada na $2^{\text {a }}$ afirmativa) que protege a diversidade biológica, deu como resultado uma posição média. Segundo essa Lei, os produtores de qualquer tipo de cultura devem se acolher e respeitar o estipulado nestas normas para poder iniciar suas atividades. No caso dos helicicultores, os respondentes entendem que os produtores de caracóis foram mediamente afetados por ela, embora o efeito não provocou uma variação significativa, quando comparados os dois períodos.

O Ministério do Meio Ambiente e o Ministério de Agricultura são as entidades encarregadas de verificar que os parâmetros expostos nestas leis sejam cumpridos. Cada produtor deve fazer um cronograma de atividades a desenvolver em cada período, a partir do conhecimento adquirido mediante visitas técnicas, palestras de conservação do meio ambiente, estudos de análise de riscos e proteção de flora e fauna, que contribuíam ao 
melhoramento do meio ambiente. Entre os anos 2003 e 2013 houve uma baixa variação no impacto produzido por essas duas Leis, correspondente a menos de 3,0\%, o quer dizer que as instituições correspondentes conservaram ou até melhoraram seus processos e procedimentos de controle. Para os produtores Cesar Rojas e Mireya Rojas, porém, hoje na Colômbia não mais programam estas atividades, os agricultores iniciam suas atividades agrícolas sem restrições ambientais, não são supervisados pelas entidades correspondentes, motivo pelo qual o meio ambiente se encontra deteriorado. Talvez essa seja a razão de que os respondentes não apreciaram significativo impacto na variação entre os períodos e uma baixa e média avaliação do efeito de suas ações sobre a atividade.

$\mathrm{Na}$ helicicultura uma atividade de alto risco de praga deveria se controlar, os produtores afirmaram que estas Leis não afetaram a produção de caracol, pelo contrário é preciso incentivar aos novos produtores a exigirem os controles requeridos para se preservar a natureza. Em quanto ao convenio das nações sua influência foi meia, o ministério do meio ambiente mantem mais controle sobre o tema, mas seu rendimento do ano 2003 até 2013 foi na baixa, devido aos poucos recursos humanos capacitados para o devido controle das atividades agrícolas. Para a helicicultura não houve influência considerável, pois os empreendimentos foram feitos empiricamente sem restrições a estas leis. Os produtores manifestam que é preciso que sejam cumpridas com rigor estas leis para garantir a preservação do meio ambiente e proteger o solo onde podem cultivar seu sustento.

A $3^{\text {a }}$ afirmativa corresponde à Lei 1.011 de 2006, que regulamenta a atividade da helicicultura na Colômbia e seus efeitos sobre a atividade. Em relação a essa Lei, revelou-se que para alguns helicicultores a mesma afetou a produção, apresentando diferentes problemas para eles, dos quais o principal foi a necessidade de obtenção das licenças ambientais. A média obtida entre as respostas foi de 3,48, o que representa ser importante, ou seja, afeta em grande parte a produção. Esta Lei contém os princípios que devem ser cumpridos para se cultivar caracóis, tais como possuir uma política ambiental para controle do impacto, processos e procedimentos de conservação dos ecossistemas presentes nas áreas de desenvolvimento, como que os produtores devem possuir um plano de manejo ambiental e um plano de manejo sanitário que permita manter um ambiente livre de contaminação, principalmente para carne de consumo humano. Segundo a proprietária Mireya Rojas, para obter a permissão de produção exigida por esta lei gasta-se muito tempo, muita documentação e muitos impostos para se começar na produção, isso faz com que atrase a movimentação da empresa. 
Para Cesar Mauricio Rojas, as entidades do governo colocam muitos problemas para a obtenção das permissões de produção. Ele manifesta "teve problemas na atividade de cria, $e$ afirma que apresentou a documentação requerida para poder importar as sementes, mas não deu certo. Seus insumos ("pé de cria") foram apreendidos pela autoridade policial por falta de documentos. Estes permaneceram quinze dias em cativeiro até que tudo fosse resolvido. Mas os animais morreram e se perdeu a oportunidade de criar caracóis provenientes de Peru". Perdeu seu investimento devido má administração das instituições. Outro ponto importante são os impostos do governo: ele afirma que estes são muito altos para pessoas que simplesmente vão começar uma produção.

Sobre esse item avaliado, o ano 2003 não se tinha um ótimo controle das unidades de produção ainda, já para o ano 2013, aumento do controle sobre o que dita a Lei resultou em menor produção de caracol, obtendo uma variação significativa de $17.2 \%$ na avaliação das respostas entre os dois períodos, o que está diretamente relacionado aos processos para se obter as permissões de produção. Estes fatores afetam economicamente e emocionalmente a produção de caracol na Colômbia e evita que se possam criar novos mercados.

A $4^{\mathbf{a}}$ afirmativa é confirmada pelas razões apresentadas acima. Com esta Lei, se decretam as licenças ambientais para as unidades produtores. Licenças de importação, licenças experimentais e comerciais. Estas licenças atualmente são outorgadas pela unidade administrativa especial de ordem nacional conhecida como ANLA. É uma entidade independente do Ministério do Médio Ambiente, esta criada mediante Decreto Lei 3.573 de 27 de setembro de 2011, que é responsável pelos projetos, obras ou atividades sujeitas ao licenciamento, permissão ou tramite ambiental. Elas fazem com que se cumpra a normatividade ambiental, e que assim possa se contribuir o desenvolvimento sustentável do País. Tem autonomia administrativa e financeira, sem estatuto jurídico, faz parte do setor administrativo de ambiente e desenvolvimento sustentável, mas ainda trabalha em parceria com a CRC.

Foram consultados arquivos da ANLA (Anexo 1) e, num total de 50 documentos, só foi possível acessar cinco pastas de empresas com seus respetivos documentos, os restantes foram reenviados à Corporação Regional do Departamento correspondente e outros foram arquivados, por apresentarem-se irregulares.

\footnotetext{
${ }^{4}$ É equivalente à semente.
} 
Segundo os helicicultores entrevistados, o maior problema está na obtenção da licença, motivo pelo qual suas avaliações se situam na média de 3,55\%, o que faz observar que esta afeta a produção. Assegura o Diretor da Asocohelix, Javier Zambrano, que os trâmites para se obter a licença são muito complicados e envolvem muito tempo; diz que muitos dos associados perderam produtividade devido ao problema. A proprietária Mireya Rojas afirma que os trâmites tomam muito tempo, ela diz que procurou obter a licença ambiental no ano 2006 para começar a produção, mas não foi possível, pois, a licença nunca foi concedida, apenas no ano 2015 ela foi outorgada já quando não se tinha mais a empresa. Já o senhor Mauricio Rojas afirma que está contemplado nos arquivos da ANLA e que foi a única empresa a obter a licença comercial devido aos fatores como tecnologia de última geração, estrutura de prédios ótimos para o cultivo e estrutura organizacional definida. A proprietária Maryerly Meneses solicitou sua licença ante a Corporação Regional do Cauca, esta está em processo, à espera de uma resposta positiva para seguir com seu empreendimento.

Ainda sobre a avaliação da $4^{\mathrm{a}}$ afirmativa, pode-se observar que o processo de obtenção das licenças apresentou média de variação de 0,20, correspondente a 5,8\% de incidência positiva das respostas, implicando em maior influência dessa variável nos tempos atuais em relação ao ano de 2003.

Enquanto o tema das instituições afirma que se devem cumprir com o estabelecido nas regulamentações, as análises das empesas necessitam realizar detalhadamente suas forças e fraquezas em torno de desenvolvimento da atividade e seguir os procedimentos para outorgar as permissões. Isso envolve tempo, participação de analistas, recursos financeiros, etc., para garantir que se protejam os recursos naturais.

Em continuidade às regulamentações, as normas técnicas de qualidade são expedidas pelo ICONTEC, que é uma entidade privada, sem fins lucrativos, cuja missão essencial é apoiar e desenvolver o produtor na defesa do consumidor, colaborando com o sector público e com o sector privado no alcançar das vantagens competitivas do País em ambos os mercados, interno e externo. Esta Norma é emitida graças à ajuda de empresas do setor, conforme informa o Comitê Técnico 210 para a Helicicultura.

A influência desta Norma é tema que envolve a $5^{\text {a }}$ afirmativa. A manifestação de influência em faixa de médio impacto $(2,50)$, não revela necessariamente a sua impressão, já que no ano 2003 ela ainda não tinha sido regulamentada. Contudo, a falta de variação manifestada para o ano de 2013 indica que ela não se apresentou maiores mudanças no setor, já que nenhuma unidade de produção foi certificada. Segundo a Técnica entrevistada do 
ICONTEC não existem empresas com certificação para poder exportar. Ela assegura que este processo requer poucas exigências a partir das outras já feitas, ou seja, uma vez que a documentação já esteja atualizada, as provas do produto são enviadas à sanidade animal, para garantir animais ótimos para consumo humano. Daí é garantida a certificação pelo INVIMA (Instituto Nacional de Medicamentos e Alimentos), estabelecimento público de posição nacional, científica e tecnológica, com estatuto jurídico, autonomia administrativa e ativa independente, pertencente ao Sistema Único de Saúde e sujeita às normas gerais que regem o seu funcionamento, responsável por garantir produtos ótimos para consumo humano. Mediante estas análises, é possível obter o certificado de qualidade, mas até o dia de hoje na Colômbia não existem registros. A pequena variação, de $4,1 \%$, identificada na apreciação da $4^{\mathrm{a}}$ afirmativa, portanto, revela mais o impacto de sua existência do que propriamente os seus efeitos.

O fato de que a produção, no ano de 2003, não havia controle e os helicicultores trabalhavam empiricamente, sem permissões e sem licenças que protegeram o meio ambiente, condicionava a Colômbia a praticar uma exportação de poucas toneladas do produto anualmente, como apresenta a Tabela 6. Depois da Regulamentação de 2006, não mais se apresentaram exportações individuais, mas sim agrupadas por produtores associados. Este fato revela os resultados encontrados nas respostas referentes à $6^{\mathrm{a}}$ afirmativa. Os resultados mostraram uma diferença (a menor) do grau de concordância dos respondentes e uma significativa variação (negativa) entre os dois períodos analisados: de $-8.4 \%$. Segundo os produtores, porém, tal Regulamentação não favoreceu a produção agrícola de pequenos produtores devido ao grande custo em impostos, pagamento de documentos, adequação da estrutura para atender as exigências e visitas regulamentares dos inspetores do Estado.

Para estas exportações e as importações de 'pé de cria' são necessários processos e procedimentos que influenciam na produção, entre estes, estão à logística, embalagens, impostos, permissões, que influenciam em qualquer processo de importação e exportação etc. $\mathrm{Na}$ Helicicultura, isso não é indiferente, pois para se puder exportar da Colômbia é preciso ter uma zona franca adequada, bons contentores, mão de obra qualificada, transporte marítimo e aéreo adequado, que garantam que o produto ofereça benefícios aos consumidores - estes são alguns dos requerimentos dos países europeus. Tais afirmativas correspondem ao predito pelos respondentes relacionados à $7^{\mathrm{a}}$ afirmativa. A influência destes procedimentos na atividade é muito alta, manifestada cm uma média das respostas (para 2003 e 2013) de 4,28. A variação entre os dois períodos, contudo, também é significativa, embora considerada baixa 
$(8,5 \%)$ - talvez pelo argumento de que a maior parte dos produtores serem de menor porte e não conseguirem se estabelecer como exportadores, pelas razões já apresentadas, consciência e conhecimento cada vez mais definido entre eles.

Vale considerar que por volta do ano 2003 estes processos foram desenvolvidos com ajuda de pessoas espanholas - é o que afirma o Diretor da Asocohelix. Havia pessoal capacitado para guiar o processo de exportação na Colômbia, isto era representado pelas poucas toneladas exportadas entre 2003 e 2006. Já no ano 2013, os produtores trabalhavam de maneira individual, obtendo resultados baixos. Segundo Alexander Forero (Gerente da Cohecol), muitas pessoas se dedicaram a vender projetos não produtivos enganando inocentes. Hoje, não existem cultivos com manejo ambiental organizado com um enfoque exportador, segundo dados de exportação do DANE para os últimos anos. (Anexo 2)

A $\mathbf{8}^{\mathbf{a}}$ afirmativa é complementar. Os requerimentos anteriormente descritos pelos países importadores têm grande influência na comercialização de produtos da atividade de. A resposta para os anos de 2003 e 2013, com média de 4.9 deixa ver que muitos produtores não possuem a capacidade econômica requerida para exportar, e é preciso que trabalhem conjuntamente formando associações que impulsionem o processo de exportação, alcancem novos mercados e possam ser reconhecidos pelos produtos de excelente qualidade. Estas exigências para os importadores são importantes já que eles têm que garantir produto ótimo para consumo humano. Uma pequena variação, de 4,2\%, não é representativa para esta afirmativa.

Quanto à variável tecnologia utilizada para esta atividade ( $9^{\mathbf{a}}$ afirmativa), foi julgada muito importante pelos respondentes, que a julgaram igualmente elevada para obter a produção planejada e de boa qualidade nos dois períodos (média de 5,0). É preciso, para tanto, bom condicionamento de energia, ventilação, elementos de controle de humidade, câmara frigorifica, calefator elétrico, cerca de vazamento elétrico, equipamento de informática, entre outros equipamentos para atividades diversas e transporte, o que envolve uma soma considerável de investimentos. Alguns produtores não possuem a capacidade de obter este equipamento todo, afirma que acondicionam ou utilizam máquinas de outras atividades agrícolas para poder investir. Por outro lado, o senhor Cesar Mauricio Rojas (Gerente da HelixdelsurColombia) afirma que o governo dificulta a importação de máquinas do exterior devido aos altos impostos de entrada no País e a pouca capacidade de inovação, isto pode levar uma perda total do investimento. Ele agrega: "Eu fiz um valioso investimento trazendo boas máquinas, e tive muitos problemas com a polícia e a DIAN (Departamento de Impostos 
e Aduanas Nacionais), mas foi possível sua entrada." Continua: "Não pode utilizar minha maquinaria devido à semente que foi apreendida e perdida, assim não poderia trabalhar no campo e perdi meu investimento. Além disso, o País não está na condição de incursionar em novos mercados, o governo não impulsiona os investimentos em novas culturas, é um governo tradicionalista."

Afirmativa 10. Entre os investimentos para tecnologia, é preciso contabilizar os custos, fator bastante influente. Estes insumos, máquinas principalmente, envolvem custos altos, principalmente para exportar, ponto de concordância entre os produtores. A média das respostas encontrada entre os respondentes é de 4,40, ou seja, alta; e faz pensar que os investimentos não são tão baixos como apresentam alguns dos trabalhos consultados no Referencial Teórico deste estudo entre eles Proaño; Lema e Valverde (2006), Arietti (2010) e Pereyraet al. (2003). As análises feitas pelos autores proporcionam valores de investimentos internos, adequados para o uso dos produtores com baixo patrimônio, ou oferecem valores convenientes para formação de grandes empresas produtivas, com expectativas fora da realidade.

Alguns produtores afirmam que alguns projetos ou análises de empresas são feitos por pessoas com pouca experiência de campo; além disso, fazem análises à conveniência deles, e apresentam resultados errados. Muitos dados devem ser revisados novamente no momento de se criar a empresa na realidade. Muitos estudantes fazem aportes com seus trabalhos e não são valorizados.

A variação expressiva da média das respostas dos respondentes sobre a $10^{\mathrm{a}}$ a afirmativa dos dois períodos, porém considerada ainda baixa $(-8,7 \%)$, reflete que esta situação (custos de produção) já foi mais relevante no passado, mas que ainda deve ser considerada.

Outro aspecto levantado na pesquisa é a formação de associações por parte dos produtores helicícolas (11 ${ }^{\mathbf{a}}$ afirmativa). Busca saber se as regulamentações sobre a produção incentivaram a criação desta. A pesquisa mostrou que parece que somente Asocohelix ajudou no desenvolvimento desta atividade na Colômbia. Contribuiu com seus poucos conhecimentos ao desenvolvimento de alguns empreendimentos, principalmente na cidade de Bogotá. Estes foram dirigidos empiricamente com algumas noções apresentadas pelos produtores espanhóis. Até o ano de 2006, antes da Regulamentação, foram produzidos poucos quilos de caracol para exportação, graças ao apoio destes estrangeiros. Nos anos seguintes, não houve produção individual exportadora e estes foram incluídos em outra posição de pauta de exportação de moluscos, razão pela qual não foi possível encontrar dados estatísticos. 
A formação destas associações, contudo, não mudou o parâmetro do incentivo à exportação entre os anos de 2003 e 2013. Mantiveram-se somente duas associações a Fedecohel e Asocohelix. Anos mais tarde, a Fedecohel desapareceu, ficando somente Asocohelix até os dias de hoje. Nota-se, porém que não houve legislação ou outra norma que influenciasse na formação ou manutenção das associações de helicicultores. A média da resposta dos entrevistados foi média nos dois períodos, com redução para o segundo período (queda de 10,3\%) agravado certamente pelo encerramento das atividades da Fedecohel.

Os respondentes concordam fortemente que a falta destas associações repercutiram no desenvolvimento da atividade (12 ${ }^{\mathbf{a}}$ afirmativa, com média das respostas de 4,35), porém, houve também uma redução nesse impacto entre os dois períodos (-6,7\%), considerado baixo.

A helicicultura não manifestava nenhum progresso de forma isolada. Havia a necessidade de se juntar forças individuais, como organizações, para que fossem utilizadas como ferramentas para se alcançar os objetivos planejados, tal como dito por Selznick (1972). Estas organizações devem sempre promover o trabalho conjuntamente, trabalhar com conhecimentos dos associados na procura de melhorar os processos e procedimentos de crescimento organizacional. Para o ano 2013, no caso da helicicultura colombiana, existia só uma associação consolidada que denotava que a regulamentação e outros fatores afetaram na consolidação de novas organizações coletivas.

Estes aspectos influenciaram no processo de criação de novas empresas ou empreendimentos relacionados de atividade comercial, neste caso, as linhas de crédito, empréstimos, seriam necessárias para influenciar no patrimônio dos produtores (13 ${ }^{\mathbf{a}}$ afirmativa). Para manter uma boa produção de caracol, é preciso que se faça manutenção do cultivo com atividades como a fertilização do solo, limpeza do cultivo, irrigação da terra, entre outras. Para isso, os produtores precisam de créditos oferecidos pelas entidades bancárias. Na Colômbia estas entidades não oferecem linhas de crédito para a helicicultura, é uma atividade desconhecida para eles. Segundo a Diretora do Banco Agrário, essa atividade não está contemplada na linha de produtores agrícolas, razão pela qual é complicado outorgar um crédito para este cultivo. Ela diz que as solicitações para esta atividade são quase nulas, o que corrobora com as manifestações dos respondentes. Para eles, (respostas com média nos dois períodos de 1,63, portanto, indicativo de pouca concordância com a afirmativa), não há credito que auxilie a atividade, e este quadro vem causando impacto crescente, já que a diferença entre os dois períodos é significativamente maior $(40,7 \%)$. 
Em relação à $14^{\text {a }}$ afirmativa, para a manutenção da atividade, é preciso que os produtores tenham em suas prioridades, meios para o transporte de produtos para exportar (ou mesmo comercializar internamente). A presença ou ausência deste influencia na produção de maneira alta. A resposta dos entrevistados confirma isso (média de 4,35). Conservam-se as respostas nos dois períodos, com pequena variação (2,3\%). Eles acham que este fator é determinante para fazer crescer o meio rural na Colômbia, e ajudar no crescimento da helicicultura como opção de crescimento da agricultura. Este processo tem envolvido multiplex atividades que poderão ser reflexadas nos preços finais.

Para contribuir com o crescimento citado, é preciso ainda que existam alianças estratégicas com o objetivo de melhorar a utilização dos recursos, aproveitar os conhecimentos da rede de distribuição e principalmente lograr economias de escopo benéficas para o País. A formação desta rede faria com que a helicicultura fosse uma atividade reconhecida nacionalmente e rentável para os produtores. Osvaldo Valencia (representante do Ministério da Agricultura) afirma que os produtores não conhecem a dinâmica da rede e os benefícios que esta pode oferecer; eles preferem trabalhar isoladamente o que evita a formação de alianças (associações e cooperativas).

A reposta dos entrevistados, manifestando impacto médio ao longo dos dois períodos $(3,15)$ é concordante com esta argumentação. Contudo, a variação positiva desta média $(17,2 \%)$ reafirma a urgência em se buscar, entre os produtores, alianças para a produção e a comercialização.

\subsection{Estrutura, Gestão e Assistência Técnica}

Para a avaliação dos aspectos em relação de estrutura, gestão e assistência técnica, foram analisadas 14 afirmações.

A primeira delas correspondente à $\mathbf{1 6}^{\mathrm{a}}$ afirmativa, que envolve o processo de assistência técnica. Deve-se ter presente que a assistência técnica é um componente fundamental para o desenvolvimento sustentável das atividades agrícola, pecuárias, florestais, porque se permite um acompanhamento integral aos produtores, facilitando e incrementando sua produtividade e competitividade. Para a helicicultura, é muito importante, pois é uma atividade que demanda um alto controle, evitando que se converta em uma 'praga' devido à alta proliferação, e demanda cuidados por representar uma produção relativamente nova, sem 
grandes conhecimentos a respeito. Segundo representantes entrevistados da UMATA (Unidade Municipal de Assistência Técnica), para esta atividade não possui um plano de dias de assistência técnica. Ela, apesar de ser a entidade encarregada pela assistência técnica, não desenvolve planos de visitas técnicas para esta atividade, por não contemplar atividades pertinentes à criação de caracol e por não possuir muitos conhecimentos específicos a produção de caracol, porém fazem visitas aos criatórios e propõem ações de produtividade baseados em outros cultivos.

Se sentindo relativamente atendidos (em assistência técnica), os respondentes apresentaram respostas que alcançaram uma média de 3,75 (considerada média). Do ano 2003 até 2013 , houve pouca variação nesta avaliação $(1,4 \%)$.

Em continuação ao elemento acima analisado, a $17^{\mathbf{a}}$ afirmativa contempla a qualidade do produto derivado de uma adequada assistência técnica e se isso ajudaria aos produtores incrementar seu capital e seu patrimônio por ampliar as vendas dos produtos e alcançar a consecução de novos mercados principalmente os internacionais.

Pelas respostas alcançadas, observou-se que do ano 2003 à 2013 não houve alteração neste processo (variação igual a $0,0 \%$ ), e a posição dos respondentes indicou uma elevada concordância (média de 4,45) com a afirmativa.

A quase ausência de pessoal capacitado para lidar nesta área (18 ${ }^{\mathbf{a}}$ afirmativa) implicou numa pontuação média de 2,93 entre os respondentes o que faz pensar que a atividade é débil com respeito à qualificação de seu pessoal. Julga-se que as pessoas (proprietários e trabalhadores rurais) são capacitadas para outras atividades agrícolas, principalmente a cafeicultura, mas não tanto à helicicultura. Os respondentes associados asseguram que por volta do ano 2007, alguns dos 'companheiros' que trabalhavam com estes empreendimentos tinham algum conhecimento, mas que hoje eles já não fazem parte da Instituição (Asocohelix). Os poucos conhecimentos são adquiridos por circulares de informação, alguns seminários e por empresas que começaram sua produção há mais tempo e permaneceram na atividade. Estes conhecimentos contribuíram ao melhoramento da atividade, que perdurou igualmente entre o ano 2003 e 2013 (indicativo de baixa variação, $1,7 \%$ ), confirmando que ainda faltam muitos aspectos por melhorar na competência dos trabalhadores.

A resposta à $1^{a}$ afirmativa complementa, indicando que o pessoal recebe capacitação constantemente, mas de forma não consistente (3,08 de média). Para tanto, sabe-se que os contratantes de forma isolada procuram informação, fazem contratos com expertos no tema, especialmente oriundos dos países europeus, assistem seminários virtuais, consultam vídeos 
na internet etc., para conhecer sobre a atividade e poder contribuir com os poucos empreendimentos de maior produtividade existentes. Esta é uma afirmativa coincidente entre a maioria dos respondestes. Afirmam que não é usual ter pessoal idôneo para helicicultura, e isso permanece ao longo do tempo, é o que se pode ver na baixa variação de 1,6\% entre o ano 2003 e 2013.

Portanto, como geralmente não se tem um plano estabelecido de visitas (de assistentes técnicos ou de outras especialistas) aos estabelecimentos (indagado na $\mathbf{2 0}^{\mathbf{a}}$ afirmativa), não existem protocolos destas, o que confirma uma média de 3,09 nas respostas, permitindo analisar que se deve melhorar este aspecto; se os estabelecimentos que fizeram seus empreendimentos se beneficiaram deste protocolo teriam alcançado sucesso. Os entrevistados manifestaram ainda haver certa descortesia da equipe da UMATA; quando fizeram solicitações para ter acompanhamento, não obtiveram resposta. Manifesta, contudo, o Diretor da Asocohelix, que a UMATA ajudou na estruturação dos empreendimentos de seus produtores associados e apoiaram a criação da Lei e as normas ICONTEC, mas entre os anos de 2003 e 2013 não houve melhora tão significativa em suas ações, contudo, tal percepção tem sido cada vez mais valorizada pelos respondentes, o que indica uma posição em maior destaque nas respostas referente ao ano de 2013 e indicado por uma variação de 5,3\%.

Como parte do crescimento na produção de caracol e preciso adquirir novos conhecimentos sobre o tema, as capacitações aos produtores fazem parte do bom desenvolvimento desta atividade. A $\mathbf{2 1}^{\mathrm{a}}$ afirmativa corrobora fortemente com essa observação, confirmada pelos respondentes, que indicaram uma média de 4,18, sendo mais pujante esta posição para o ano de 2013.

Este tipo de capacitação permite manter atualizados os conhecimentos, estar na vanguarda de novas máquinas e implementos, novos insumos, novas técnicas de produção etc., que ajudam no aumento da produtividade dos empreendimentos. Esta debilidade tem estado presente durante estes 10 anos; não mudou. Entretanto, há maior pressão para que ocorram - indicado na variação positiva, embora ainda baixa, de 6,2\%.

Coerente à tal pensamento, a $\mathbf{2 2}^{\mathbf{a}}$ afirmativa indica que mediante estas capacitações se apresentam os resultados das pesquisas feitas nos países que desenvolvem adequadamente esta atividade, os avanços tecnológicos e os novos insumos requeridos para a produção. A elevada concordância dos respondentes sobre este aspecto é indicativo de um fator determinante na vida produtiva da helicicultura, donde se pode observar por meio da média de 4,50 em 2003 e 2013. Contudo, vale considerar que para os produtores muitas vezes é difícil importar estes insumos, os países exportadores colocam altos preços nos insumos que podem 
ser adquiridos por outros países que detêm solvência econômica; para um pais como a Colômbia pode ser complicado.

$\mathrm{Na} \mathbf{2 3}^{\mathrm{a}}$ afirmativa é contemplado o fato de que a quantidade de fornecedores e qualidade dos insumos tem alta influência na qualidade do produto. A concordância encontrada entre os respondentes é alta, representada na média de 4,30, embora decrescente entre 2003 e 2013 (variação de -6,7\%). Isto implica que o produto será de boa qualidade devido à qualidade das matérias primas. Deve-se incorporar aos fornecedores das matérias primas à administração da qualidade total, mediante procedimentos utilizados para avaliar a capacidade dos fornecedores, selecionar e melhorar as operações dos produtos e seus serviços, garantindo qualidade da produção e atendendo as exigências dos consumidores.

Os custos dos insumos influenciam no desenvolvimento da helicicultura. Essa representa a $\mathbf{2 4}^{\text {a }}$ afirmativa. Os respondentes asseguram que os insumos para essa atividade não são de fácil movimentação, quer dizer que o retorno do investimento para os produtos é muito lento. Para adquiri-los envolve custos como os de transporte, impostos dos fabricantes e para os fornecedores etc. As respostas à essa afirmativa apresenta uma média entre os dois períodos de 4,08, indicativo de elevada influência. Nota-se também que os respondentes indicaram uma menor influência para o ano de 2013, embora pouco significativa (variação de $-3,6 \%$ ). Alguns dos produtores afirmaram que existem poucos fornecedores e estes oferecem baixa qualidade a preços altos. Alguns dos produtores afirmaram que no ano de 2007, no auge das empresas produtoras de caracol, havia muitos fornecedores, os mesmos que fornecem insumos para outros cultivos, garantindo insumos de boa qualidade, o que ajudou a fortalecimento dos cultivos. Hoje, contudo, eles não mais atendem ao setor.

Outro fator determinante para a produção e que representou uma média de 3,75 entre 2003 e 2013 são as vias de acesso para transporte dos produtos como determinantes ao bom desempenho da atividade - indicativo da $\mathbf{2 5}^{\mathbf{a}}$ afirmativa. A concordância média para essa afirmativa indica que este elemento não é tão preponderante, mas tem se tornado maior, já que tal afirmativa cresceu de importância, na opinião dos respondentes, em relação ao primeiro período: variação de 5,5\%. Os produtores não precisam incursionar em novos mercados, precisam estar presentes no mercado. A mobilidade na zona rural na Colômbia é, de maneira geral, ruim, e é feito por veículos a motor, pequenas motocicletas, carroças puxadas por animais, bicicletas, canoas e a pé. Muitas estradas são feitas de pedra, com impossível acesso de caminhões, o que impede uma logística eficiente em maior escala. Alguns produtores fazem venda para atravessadores, aqueles que recolhem a produção na localidade. Quando a 
helicicultura começou, com uma pouca produção, para diminuir custos do produtor, um recolhedor fazia esta atividade em conjunto com Asocohelix.

Os entrevistados manifestaram que o governo não faz investimento no melhoramento das vias da zona rural, dizem que esta parte da população fica esquecida dos planos nacionais. Além disso, afirmam que o setor agrícola aporta uma grande quantidade do PIB da Colômbia e contribui ao desenvolvimento econômico do País, razão pela qual se deveria incentivar a produção, mas o governo presta pouca atenção ao camponês que trabalha na terra e faz investimentos para outros ramos. Em suas manifestações, pedem mais ajuda para continuar "brindando a produção ao país".

Outro fator determinante para a produção está relacionado aos recursos naturais, apresentado na $\mathbf{2 6}^{\mathbf{a}}$ afirmativa: as características do clima, a temperatura do ambiente e o solo. Os respondentes indicaram extrema importância para ambos, que encontrou uma média entre suas influências nos dois períodos de 4,93, alta, embora com uma pequena e negativa variação $(-3,0 \%)$, indicando uma menor dependência do clima na atualidade.

Para desenvolver a helicicultura deve ter condições especiais, tais como as apresentadas no Quadro 2. Alguns helicicultores afirmaram que as condições que a Colômbia possui para este cultivo são ótimas. Entre eles, o senhor Cesar Maurício Rojas (Gerente da HELIX DEL SUR COLOMBIA) diz que “[...] mesmo se as condições são boas se deve implementar outras para o ótimo desenvolvimento dos animais. Por exemplo, para a fase de crescimento se deve ter mais cuidado, devem ficar no campo fechado com baixas condições de luz" e complementa "[..] já na etapa de engorda, se deixam no campo aberto com as condições normais do ambiente".

Hoje em dia, com as mudanças climáticas, é difícil ter controle sobre os cultivos. Com o fenômeno El Niño, se apresenta muito calor em alguns períodos, o que pode ressecar a terra e deixar inférteis os animais por não terem como se alimentar. De forma contrária, o fenômeno La Niña produz muita chuva, o que faz com que haja muitas inundações e os animais morra.

Em relação à dependência de mão de obra qualificada, indicativo da $\mathbf{2 7}^{\mathbf{a}}$ afirmativa, observa-se uma dependência cada vez mais alta na helicicultura. Embora a média encontrada entre os dois períodos tenha sido de 3,93, a sua elevação no segundo período é substancial (de 3,60 para 4,25), indicando uma variação de $18,1 \%$. Isto permite observar que se deve capacitar os trabalhadores para o cultivo e/ou deve-se contratar pessoal idôneo com conhecimentos sobre a atividade. Diferentemente dos cultivos de café, afirmam os entrevistados, para a helicicultura é complicado contar com mão de obra cambiante e pouco 
qualificada. A variação do ano 2003 para $2013(18,1 \%)$ pode indicar que a helicicultura tinha sido reconhecida como atividade agrícola e as empresas estejam capacitando os seus trabalhadores (ou os produtores familiares buscando sua capacitação).

Entre os fatores mais influentes para a atividade, entre os avaliados, são os processos de inovação e pesquisa. Alguns respondentes manifestaram ser a Colômbia um país que pouco apoia os pesquisadores. O processo de inovação é o ponto forte em todo setor, as empresas devem fazer investimentos em inovação, buscando obter maior valor agregado em seus produtos. Para lograr a inovação, contudo, há de se deve ter um departamento de pesquisa que possa analisar as necessidades dos consumidores e melhor aproveitar seus recursos, com o fim de obter maiores resultados. Na Colômbia, a helicicultura tem sido incipiente, pouco desenvolvida, e um dos fatores pode ser o baixo investimento em pesquisa e inovação.

Graças a esse pensamento, a valoração da influência da pesquisa e inovação para o avanço da helicicultura alcançou elevado parâmetro entre os respondentes (5,00 e 4,90 para os dois períodos), indicando pequena variação $(-2,0 \%)$. Isso talvez faça pensar que as instituições, universidades e institutos não apoiam a pesquisa. O que pode não refletir em uma verdade, mas certamente torna-se verdade quando especificamente se diz a respeito da helicicultura. Acredita-se que investir em novos mercados, novas tecnologias agrícolas, novos produtos e incentivar a criatividade das pessoas para que possam ser reconhecidas e se transformam um exemplo para o resto do mundo. A helicicultura pode fazer parte dessa perspectiva.

Por último, um fator de igual de importância e com o qual sofre a Colômbia há algum tempo são os conflitos sociais e políticos que afetam, em especial, a população rural. Estes, indicativos da afirmativa 29 vêm representados pelos grupos à margem da lei, que se trata de 'guerrilha, paramilitar', e que repercutem na delinquência em diferentes maneiras, e que fazem da população rural pessoas perdidas em um campo de guerra. Muitos agricultores deixaram suas terras devido ao deslocamento destes grupos; isso afeta a economia a e agricultura do País, pois não se terão bons cultivos em torno dessa realidade. Alguns respondentes indicam que estes grupos alteram a tranquilidade dos moradores das regiões, e que quando estes vão prosperando num empreendimento, aqueles cobram valores sobre as vendas, o que traz perda dos ganhos dos produtores. Os respondentes asseguram que os produtores não tem como desenvolver um bom manejo e atender as demandas destes grupos. 
A elevada concordância permanece com médias próximas do máximo, com elevação no segundo período $(4,80$ e 4,90). O que indica uma permanência do problema (variação de $2,1 \%$ ) mesmo em períodos em que indicam tendência de paz.

\subsection{Rede e Associações de produtores}

Para a avaliação dos aspectos em relação de redes e associações de produtores foram analisadas 5 afirmações dando como resultado:

$\mathrm{Na} 30^{\mathbf{a}}$ afirmativa referente a uma rede consolidada de helicicultores apresento uma media de $3.10 \%$ que mostra que esta atividade poderia ter sucesso se é organizada uma rede de participantes produtores já sejam aqueles que possuem pequenos hectares de terra, cooperativas, associações como Asocohelix e empresas agroindústrias envolvidas na helicicultura, as quais fazem acordos para conseguir um desenvolvimento economicamente equitativo, socialmente justo e ambientalmente sustentável com o objetivo de ajudar no crescimento da região e o país. Esta rede poderia criar laços de união, de cooperação mutua que faria que conjuntamente esta atividade pudesse surgir.

Atualmente existe a Asocohelixa qual é uma agremiação sem animo de lucro, criada no ano 2001, com 23 pessoas, para o ano 2010 tinha 9 (nove) inadimplentes, com sua principal oficina na cidade de Bogota e sub escritórios nas cidades de Cali, Medellin e a zona cafeteira. Segundo dados informados pelo diretor Javier Zambrano (2015), para o mesmo ano tinha 32 empresas familiares em diversos municípios como Sisga, Cajica, Calera entre outros. Esta associação tem como objetivo social promover a vinculação de pessoas naturais ou jurídicas como sócios, para desenvolver e fortalecer a helicicultura. Conta-se com um grupo interdisciplinar capacitado para contribuir ao fortalecimento do setor (ZAMBRANO, 2015).

Sua missão é promover, fomentar e capacitar no desenvolvimento da helicicultura na Colômbia mediante cursos, assessorias e publicações, promover o consumo de carne de caracol a nível nacional por médio de degustações, receitas para a casa, campanhas publicitarias que aumente o consumo desta carne mais saudável. Prestar assessorias na execução e montagem dos campos para o desenvolvimento da atividade, assim fazer uma elaboração de estudos econômicos e de impacto social que gerem os mesmos. E por ultimo fomentar a elaboração de projetos produtivos de impacto social para executara-los conjuntamente com pessoas naturais, entes governamentais e entes privados, prestando apoio 
às pesquisas cientificas cujos propósitos sejam o desenvolvimento de novos usos ou produtos em relação com o cultivo de caracol. (ASOCOHELIX, 2015)

Entre sua visão procura ser a entidade líder no grêmio da helicicultura, lograr a legalidade dos cultivos na Colômbia, ter um padrão de cultivo a nível nacional, melhorar a qualidade dos produtos, incentivar o desenvolvimento agroindustrial no setor alimentício não tradicional ao oferecer alternativas nas técnicas de cria, produção, processamento e comercialização, permitir a utilização de subprodutos como concha, enzimas, vísceras para aplicações medicas, industriais, cosméticas e artesanais. (ASOCOHELIX, 2015)

Entre as vantagens da vinculação estão:

Atualização e informação permanente sobre avanços tecnológicos na helicicultura.

$>$ Descontos aos eventos organizados pela associação.

$>$ Desconto na compra de insumos e materiais requeridos para o desenvolvimento do cultivo.

$>$ Assistência técnica permanentemente em baixos custos.

Assessoramento para tramites de licenças ambientais e sanitárias em baixos custos.

$>$ Favorece a troca de tecnologia, animais entre outras ferramentas entre seus associados.

> Canalização da produção para a comercialização.

$>$ Ter voz e voto ante outras entidades helicícolas e entidades nacionais.

No ano 2006 quando é regulamentada esta atividade mediante lei 1011, chegaram aos 18.000 helicicultores, para o ano 2010 só tinha 1500 helicicultores dos quais 60 no departamento de Antioquia fizeram parte da associação, envolvendo outros. Atualmente tem 13 produtores localizados nos departamentos de Cundinamarca, Antioquia, Boyacá e Caldas. Entre estes helicicultores se encontram arquitetos, donas de casa, aposentados de Ecopetrol, agricultores, administradores de empresas. (RODRIGUEZ et al., 2011; ZAMBRANO, 2015)

São poucos os produtores que fazem parte dela, ainda faltam muitos conhecimentos por apender, com a formação desta associação foi possível fazer visível esta atividade e poder exportar poucas toneladas de caracol para o ano 2006 e 2007, mas hoje todo ficou na decadência pode-se ver na variação de $0.40 \%$.

A estrutura organizacional desta rede influencia no desenvolvimento desta atividade, já que é possível conhecer os procedimentos adotados e a forma de ver como funciona o sistema em suas partes de composição. $\mathrm{Na} \mathrm{31}{ }^{\mathbf{a}}$ afirmativa mostra uma media de $2.40 \%$ que 
apresenta uma falência neste aspecto, não se tem uma estrutura organizacional. Numa organização como Asocohelix falta pessoal idôneo para manter uma pirâmide organizacional, conta-se com um grupo de pessoas que ajudam na organização, mas não se tem tarefas especificas para cada uma, elas cumprem com diversas funções. Entre o ano 2003 e 2013 não tive variação, ficou constante.

Não possuem um manual de processos e procedimentos que sistematizem a informação dos diferentes postos de trabalho, das funções e responsabilidades assignadas a cada cargo. Isso faz simples o entendimento das atividades desenvolvidas pelos colaboradores, também pode contribuir nas analises dos resultados obtidos já sejam bons ou ruins e tomar decisões frente aos mesmos. Contemplar métodos de controle e seguimento com o fim de ter uma auto-avaliação dos logros obtidos. Foi ruim na variação entre os anos 2003 e 2013 com uma percentagem de $-9.3 \%$ vai pior. Já na $32^{\mathbf{a}}$ afirmativa apresenta uma media de $2.58 \%$ que influencia no desenvolvimento desta atividade. Para que esta associação possa contribuir aos aportes da helicicultura é preciso que o plano estratégico seja bem definido planejando os objetivos e metas por cumprir. Sua variação para o ano 2013 foi de $-9.3 \%$ o que conclui que se devem fazer reformas e acondicionar os processos ao ambiente atual.

Outro fator importante e de alta influencia entre a rede é a relação que esta possa ter com as instituições envolvidas na produção de caracol. Hoje em dia com os processos de globalização os atores envolvidos participam ativamente das politicas publicas que beneficiem os setores da economia, para a helicicultura é importante que estes contribuam na criação de benefícios para os produtores. Sua media de 3.93\% alta faz pensar que é de grande influencia, pois as instituições são as direitas responsáveis do crescimento econômico do país, porem devem apoiar as redes de produtores mediante projetos benéficos para todos. ( $\mathbf{3 3}^{\mathbf{a}}$ afirmativa)

Estas boas relações fazem que as instituições encargadas possam procurar as relações sociais entre os países que ajudem na exportação dos produtos agrícolas, especialmente a carne de caracol que pode ser enviada aos países europeus onde há grande demanda deste molusco. As relações do ano 2003 para o ano 2013 melhorou um pouco. (6.6\%)

Por ultimo a relação dos associados na toma de decisões influencia no $3.98 \%$ dita na 34 afirmativa. Os associados comprometidos são aqueles que recebem benefícios e valoram o que esta lhes oferece, assim devem dedicar parte de sue tempo para ajudar nas atividades que a associação requer porque os resultados serão benéficos para todos. Estes devem estar de acordo com o plano estratégico planejado. A voz e voto dos associados num problema podem contribuir a sua solução mediante chuva de ideias de cada participante. Cada um aporta um 
grão de areia para que os objetivos planejados sejam alcançados sem contratempos. Também é beneficiado dos ganhos que esta possa oferecer.

\subsection{Unidade produtiva}

Para a avaliação dos aspectos em relação à unidade produtiva foram analisadas 6 afirmações dando como resultado:

Segundo a revista Semana (2012), 94\% do território do País é rural, onde se encontra $32 \%$ da população. Estas estatísticas mostram que se tem muita terra por explorar. Referente à 35 afirmativa, os entrevistados manifestaram que suas terras são ótimas para cultivar qualquer tipo de cultura, são terras férteis, possuem grande quantidade de água, têm variações de temperatura e humidade etc. Suas respostas corresponderam á alta aproximação (média de 4,93 nos dois períodos, com baixa variação, 1,0\%). Admitem haver uma boa extensão de terra para os cultivos e que os solos apresentam uma boa composição, já que os caracóis precisam de nutrientes para seu correto desenvolvimento, oferecem suportes que os abrigue e lugares ótimos de cria, para evitar que fugam ou que os predadores os machuquem. Suas terras contém ainda grande variedade de flora que ajuda na alimentação dos caracóis, fazendo com que a sua carne tenha um alto conteúdo de cálcio e ácido poli-insaturado, minerais e ferro. Não só é a extensão da terra mais também a qualidade da mesma é fator que influencia no cultivo de caracol.

Estas informações permitiram a elevada concordância dos respondentes para com a 36 ${ }^{\mathbf{a}}$ afirmativa (4,20 para 2003 e 4,50 para 2013; média de 4,35). Contudo, para este aspecto (qualidade dos solos para ao cultivo), a variação positiva entre os dois períodos $(7,1 \%)$ corresponde ao fato de que no ano 2003 estas terras não tinham tratamento especial, já para o ano 2013 houve significativa melhora nesse aspecto, quando os produtores aprenderam técnicas e passaram a melhor cuidar e fortalecer os solos.

Para a Helicicultura é de grande importância que os caracóis tenham bom desenvolvimento. Segundo os entrevistados Carolina Prada (Gerente da A comer caracol), Javier Zambrano (Diretor da Asocohelix) e Cesar Mauricio Rojas (Gerente da helix del sur Colômbia), a Colômbia tem diversidade de flora e fauna que permite que nos deferentes Departamentos se desenvolvam atividades agrícolas, principalmente cultivos de camponeses. Entre os anos de 2003 e 2013, a variação positiva de 7,1\% se deve à ampliação das extensões 
de terra que foram oferecidos pelo governo, para que a população rural continuasse em crescimento e pudesse assim contribuir no desenvolvimento econômico do País.

Continuando com as afirmativas, a $\mathbf{3 7}^{\mathbf{a}}$ argumenta sobre a importância da capacidade dos recursos que possuem os produtores para cultivar. Sua média entre os dois períodos foi de 4,15, subindo de 3,95 (2003) para 4,35 (2013). Isto revela a grande dependência que tem os produtores para com o capital. Para os pequenos produtores colombianos é de grande importância que aquelas coisas que foram herdadas de seus antepassados sirvam como base para começar uma atividade e a manutenção do patrimônio. Eles afirmam que trabalham com seu patrimônio composto principalmente pela terra, casa e animais de comercialização, como forma de investimento para obter ganhos e fazer créditos, e asseguram a dívida com suas posses.

Houve um tempo em que a Helicicultura teve um desenvolvimento fraco, movida por projetos que enganavam aos camponeses, oferecendo bons rendimentos mediante a sua compra e implantação - nem sempre compatíveis às suas condições -, ou seja, para poder implementar o projeto as pessoas tinham que pagar um alto valor por seu conteúdo. Tais projetos exigiam capacitações no exterior, compra de semente e fertilizantes, entre outras coisas, gerando elevados ônus aos produtores. Tal situação promoveu a realização de prejuízo a muitos produtores e o êxodo de muitos da atividade. Atualmente, acredita-se na necessidade de apoio financeiro para que os produtores possam desenvolver a atividade. Esta realidade é revelada pelos respondentes por meio da variação significativa entre os anos 2003 e 2013, de $10,1 \%$. Nota-se que a oferta de recursos melhorou devido ao governo ter entregado algumas fazendas aos camponeses, favorecendo o patrimônio de algumas pessoas.

Para trabalhar a terra é importante contar com bons trabalhadores. Na Afirmativa 38 fala-se do tipo de mão de obra escolhido pelos donos dos projetos e da terra. Asseguram que os cultivos são feitos por pessoas da região que adquiriram seus conhecimentos empiricamente. No campo da Helicicultura, faz falta de pessoas que conheçam do cultivo, que façam as coisas corretamente, que utilizam adequadamente as proporções requeridas dos insumos. Isto é um ponto fraco da atividade, revelado pelos respondentes com uma média baixa $(2,38)$ entre os períodos. Contudo, há uma variação negativa $(-10.0 \%)$ que quer dizer que há falta crescente de capacitação para os trabalhadores a fim de garantir o crescimento e a qualidade da produção. A capacitação para estes é ainda apresento na $\mathbf{3 9}^{\mathbf{a}}$ afirmativa. Com uma média igualmente baixa (de 2,20), tal resultado mostra que se deve ter um plano de capacitação para o pessoal antes de se começar na atividade, se deve especificar o meio onde essa vai se desenvolver, os métodos de cultivo, os processos e procedimentos da empresa afim 
de se buscar alcançar uma apropriação da identidade da empresa. Deve-se avaliar o clima e a cultura organizacional para evitar inconvenientes entre o pessoal; cuidar de seus direitos e fazer cumprir seus deveres, permitindo assim que a empresa cresça organizacionalmente e principalmente na parte econômica. Tal afirmativa manteve a mesma média nos dois períodos, indicando a recorrência do problema.

Por último, a afirmativa 40 argumenta a venda da produção à terceiros independente da associação e sua influência no resultado do empreendimento. Este fato mostrou-se de menor importância (média de 3,40 entre os dois períodos). Faz pensar que na Colômbia não apresentam muitas associações que possam comprar esta produção. Como se observou anteriormente, a associação mais concisa é a Asocohelix e esta não comercializa diretamente. Para os helicicultores é mais viável vender sua produção principalmente aos restaurantes, ao recolhedor da região que pode pagar um bom preço pela produção dos pequenos produtores. Do ano 2003 à 2013 houve uma variação na resposta dos respondentes de 6,1\% para mais. Isto indica que há um interesse maior pelo associativismo. 


\section{CONCLUSÕES}

Conhecer os aspectos organizacionais e institucionais de uma atividade produtiva, como é o caso da Helicicultura, pode oferecer uma completa visão do desenvolvimento da mesma, ou seja, ajuda no reconhecimento dos pontos fortes e fracos que fazem crescer ou debilitar economicamente a produtividade desta atividade.

Conforme apresentado, observa-se que a Helicicultura não demonstrava um ótimo desenvolvimento na Colômbia, no início da última década, era uma atividade agrícola que se implementou empiricamente, sem conhecimentos prévios e sem regulamentação específica. Este fato era confirmado pela pouca quantidade de toneladas produzidas e exportadas, e principalmente, pelos poucos dados que se apesentam desta atividade. A partir de sua regulamentação, como atividade agrícola, em 2006, alguma melhora no quadro produtivo foi apresentado, mas carente de apoio que substanciasse a produção e sua exportação.

A Helicicultura não possui uma cadeia produtiva definida. Estudiosos desta atividade tomam como base outras cadeias produtivas, tais como a do café, o que lhes permite corresponder ao desenvolvimento e a identificação dos atores participantes. São assim adotados processos e procedimentos que garantem a tomada de decisões frente às mudanças do entorno e as exigências dos consumidores.

Os aspectos mais importantes que melhoraram significativamente a produção de caracol nos dois períodos de análise (2003 e 2013) e indicados pelos respondentes do estudo foram (Quadro 11): a presença de uma linha de créditos outorgada pelos bancos para desenvolver esta atividade (40,7\%); a presença de uma mão de obra pouco qualificada (18,1\%); a implementação da Lei 1.011 de 2006 que passou a reger a Helicicultura na Colômbia (17,2\%); a falta de alianças estratégicas entre produtores e organizações (17,2\%); a existência de uma rede 'decadente' consolidada de helicicultores $(13,8 \%)$ e, por último, a necessidade de recursos financeiros para alavancar a produção, por parte dos helicicultores $(10,1 \%)$.

Estes fatores, principalmente a capacidade creditícia, fez com que muitos produtores não tivessem condições de fazerem investimentos, mas depois o governo apoiou aos produtores. Politicamente, observou-se que a Helicicultura sofreu dificuldades para se desenvolver. O governo impediu a criação de novas empresas, devido à alta burocracia que ainda existe no País, à ignorância e arbitrariedade dos funcionários públicos, o maltrato destes para com os helicicultores e, principalmente, os altos impostos e as dificuldades para a obtenção de licenças ambientais. 
Quadro 11. Resumo dos resultados da comparação dos anos

\begin{tabular}{|c|c|c|}
\hline Item de Variação & $\%$ & Fator Influente \\
\hline \multirow{6}{*}{$\begin{array}{l}\text { SIGNIFICATIVAMENTE } \\
\text { MELHOR }\end{array}$} & $40,7 \%$ & Linhas de credito \\
\hline & $18,1 \%$ & Mão de obra qualificada \\
\hline & \multirow{2}{*}{$17,2 \%$} & Lei 1011 de 2006 \\
\hline & & Alianças estratégicas \\
\hline & $13,8 \%$ & Rede consolidada de helicicultores \\
\hline & $10,1 \%$ & Capacidade de recursos financeiros \\
\hline \multirow{7}{*}{ POUCO MELHOR } & $7,10 \%$ & Qualidade da terras \\
\hline & $6,60 \%$ & Relação das redes com as instituições \\
\hline & $6,20 \%$ & Capacitações \\
\hline & $4,10 \%$ & Norma técnica de qualidade \\
\hline & $2,10 \%$ & Conflitos sociais, políticos \\
\hline & $1,40 \%$ & Ater \\
\hline & $1,00 \%$ & Capacidade da terra \\
\hline \multirow{4}{*}{ NADA MUDOU } & \multirow[b]{4}{*}{$0 \%$} & Tecnologia \\
\hline & & Capacitações aos produtores \\
\hline & & Trabalhadores \\
\hline & & Estrutura organizacional da rede \\
\hline \multirow{4}{*}{ POUCO PIOR } & $-9,30 \%$ & Processos e procedimentos da rede \\
\hline & $-8,70 \%$ & Custos da tecnologia \\
\hline & $-8,40 \%$ & Licenças ambientais \\
\hline & $-2,40 \%$ & Convenio das nações \\
\hline \multirow{2}{*}{ SIGNIFICATIVAMENTE PIOR } & $-10,30 \%$ & Formação de associações \\
\hline & $-10,0 \%$ & Mão de obra disponível \\
\hline
\end{tabular}

Fonte: elaborado pela autora

Os outros aspectos observados que afetaram em demasia a atividades referem-se: aos processos de exportação, aos requerimentos da parte dos países importadores, a fragilidade no transporte de insumos e produtos, a falta de associações voltadas ao interesse da exportação, a assistência técnica incipiente ou ausente, a precária capacitação de trabalhadores e agentes públicos, a ausência de fornecedores, os elevados custos de insumos, a falta de inovação, os conflitos sociais, a limitação de espaço (terra) ofertado aos produtores e a queda na qualidade das terras. Todos estes elementos manifestaram-se impactantes à produção e ao comércio de 
caracóis ao longo do período, gerando efeitos no efetivo de produtores e associados ao longo desse período de 10 anos.

A tecnologia utilizada, a assistência técnica, as capacitações aos funcionários e produtores, a estrutura organizacional da rede não apresentaram, no período, mudanças em seu impacto. Ficaram do mesmo jeito durante estes 10 anos, isso devido à pouca atenção por parte das instituições para conseguirem assegurar garantias de mercado e, aos produtores, por não assegurarem um desenvolvimento econômico e melhoramento das condições de vida. Se se apresenta uma rede bem definida e organizada, é possível que esta atividade tivesse um maior grau de importância na agricultura colombiana, ajudando os produtores a se desenvolverem, os diretamente beneficiados. Esta rede poderia lograr trabalho conjuntamente entre os atores envolvidos e se consolidar econômica, social e culturalmente esta atividade, vindo ela a contribuir ao PIB do País.

Cabe ao governo colombiano incentivar os produtores a cultivarem caracóis, para que novos produtos venham a fazer parte do mercado de exportação, satisfazendo ou criando as necessidades dos consumidores, com o objetivo de obter ganhos econômicos. Contrariamente, o que se observou foi que, com a implementação da Lei de Regulamentação da atividade foram restritos muitos processos, impedindo a implantação de novas plantas e gerando dificuldades aos produtores, principalmente por gerar excessivos controles para a proteção da natureza.

Os restantes de aspectos apreciados nas afirmativas avaliadas pelos respondentes demonstraram uma maior fragilidade com o passar do tempo após a Regulamentação, tais como a ampliação dos custos da tecnologia, a falta de associações e a mais impactante, a ausência de mão de obra qualificada - fatores determinantes que fazem com que o produto comercializado seja de boa qualidade.

A Colômbia é um País carente de inovação e pesquisa em quanto ao tema da helicicultura, falta incentivar aos jovens no empreendedorismo no campo, para que a produção não seja tradicional, mais sim com boas bases tecnológicas e assim, seja diversificada, o quer dizer que sejam cultivados sempre os mesmos produtos. As possibilidades de se criar uma empresa e a possibilidade de se entrar em novos mercados é quase nula. Fato que intervém na estagnação da economia de um País.

Adiciona-se o fato de que as pessoas envolvidas na produção e no comércio da Helicicultura de forma gremial ficam prejudicadas; os produtores da Colômbia têm a cultura do trabalho isolado, eles acham que é mais produtivo fazer as coisas por suas próprias mãos do que com outros e, além disso, economicamente, acham que podem ter mais ganhos do que 
se associarem. Eles argumentam que não se interessam por se sindicalizar porque não encontram pontos de consenso com as pessoas ligadas à atividade, uns trabalham mais do que os outros.

A assistência técnica, o acompanhamento, as assessórias, os seminários, oferecidos por instituições relacionadas à produção e à comercialização do caracol permitem, em primeiro lugar, gerar conhecimento sobre essa atividade, em segundo, fortalecer o setor para que este seja mais competitivo e, finalmente, lograr alcance a mercados internacionais como a Europa, onde a demanda ainda este por ser satisfeita.

Necessário se faz ainda proporcionar meio para melhoria das terras colombianas, para que se possa melhorar a produtividade, tratando a terra e cuidando das áreas naturais e das aguas, afim de que se permita lograr a melhor qualidade do produto.

Organizacionalmente, as empesas de organização coletiva (associações de produtores) devem adoptar um sistema ordenado que permita aos produtores identificar, controlar e definir adequadamente as atividades desenvolvidas na unidade de produção. $\mathrm{O}$ mesmo deve ser feito para a gestão da própria associação. É de vital importância para o controle interno da organização, saber se os trabalhadores estão cumprindo suas funções. Deve ser entendível para qualquer pessoa e requer que seja atualizado, isso facilita os labores e a inclusão dos novos empregados.

Finda essa análise conclusiva, julga-se completo atendimento dos propósitos desse estudo e, especialmente, dos objetivos propostos. Acredita-se que, ao estudar novas culturas, como a criação de caracol, gera-se importância às pessoas, por apresentar novas oportunidades de negócios, novos empreendimentos que possam contribuir no desenvolvimento econômico de um País, e novas alternativas de produtos, no caso, alimentares. A repercussão de estudos dessa natureza atende aos interesses até de outros países e continentes. O Brasil pode inclusive vir a adotar esta cultura.

Para os pesquisadores e empreendedores interessados, este estudo gera um importante meio de adquirir novos conhecimentos nesta área. Podem abarcar novos projetos e tomar como base o método, as análises e os resultados desenvolvidos no curso desta pesquisa.

Por fim, como limitações ao estudo, julga-se pertinente enumerar a falta de informações disponíveis (por se tratar de uma atividade pouco convencional na Colômbia); a distância, já que se refere a uma atividade em outro país e distante da sede do Programa de Mestrado; e a limitação orçamentária para o atendimento das demandas requeridas pela pesquisa. 


\section{REFERENCIAS BIBLIOGRÁFICAS}

AMORÓS, E. Comportamiento organizacional en busca del desarrollo de ventajas Competitivas. 2007. Aragón

ARIETTI, D. G. Helicicultura Aspectos controvertidos de su valuación en el impuesto a las ganancias. 2010. 67f. Monografia (Especialización en Tributación)- Facultad de Ciencias Económicas y Sociales, Universidad Nacional de Mar de Plata, Mar de Plata, 2010.

Asi es Colombia rural. Revista semana, Bogotá, 2012. Disponível em $<$ http://www.semana.com/especiales/pilares-tierra/asi-es-la-colombia-rural.html $>$ Aceso em Janeiro de 2016.

ASOCIACION DE CRIADORES HELICICULTORES DE ANDALUCIA. Espana. Portal em linea. Disponível em: <http://achaweb.com/>. Acesso em: Janeiro 2015.

ASOCOHELIX. Portal Intitucional. Disponivel em $<$ http://asocohelix.galeon.com/ $>$.Acesso julho de 2015.

BRAGA, A. C. Redes e sociologia econômica. 2009. São Carlos: Edufscar. 2009

BRAIDOT, N. E. Desarrollo de una metodología de diagnóstico para empresas pymes industriales y de servicios: Enfoque basado en los sistemas de administración para la Calidad Total, Diagnostico pára empresas PyMEs industriales y de servicios. 2003.

BRISOLA, M. V. Upgrading industrial na Argentina e no Brasil: uma análise histórica e comparada da relação entre o Estado e as associações empresariais industriais. 2013. 424 f. Tese (Doutorado em Ciências Sociais) - Universidade de Brasília, Brasília, 2013.

CARDOSO, V.C.; ALVAREZ, R.R.; CAULLIRAUX, H.M. Gestão de competências em redes de organizações: discussões teóricas e metodológicas acerca da problemática envolvida em projetos de avaliação, 2002, Rio Grande do Sul. Anais... Rio Grande do Sul: XXVI Encontro ANPAD, sp. 2002.

CASTILLO, R.A.R; CASTILLO, A.C. Centro de promoción y desarrollo de

lahelicicultura. 2002. Trabalho de conclução de curso (Ingeniero Industrial)- Universidad Nacional de Ingenieria, Lima. 2002.

COLIGNON, R. A. Powerplays: criticalevents in theinstitucionalizationofthe Tennessee Valley Authority. Albany: StateUniversityof New York Press, 1997.

DA CUNHA, A. S; SOARES, T. C; DE LIMA. M.A. a Institucionalização como forma de diferenciação frente ao isomorfismo organizacional. Revista de Administração, v.3, n. 2, abr/set. 2011.

DELGADO, L. A; ALONSO, M. C. S; ARRUBLA, A. P. Formulación de la cadena productiva del caracol en Cundinamarca y Boyacá- Colombia para exportar hacia el mercado español. Revista U.D.C.A Actualidad y Divulgación Científica, Bogotá,v.12, n.1, p. 163$172,2009$.

DEPARTAMENTO ADMINISTRATIVO NACIONAL DE ESTADISTICA (DANE). Dados enviados pelo e-mail. Grupo ventas directas, Direccion de Difusión, mercadeo y Cultura estadística. 2015.

DOS SANTOS, R.A., DE ALMEIDA, B.L., CROZATTI, J. Considerações Sobre o Processo de Institucionalização de Área Organizacional de Controladoria: Uma Abordagem de Interação da Visão da Psicologia Humana, Cultura Organizacional à Teoria Institucional.

XXXI Encontro ANPAD: Rio de Janeiro. 2007 
FREITAS, J. B. Formação e gerencia de redes de empresas: requisitos para a adequação do planejamento e controle da produção- estudo de caso em obra de construção civil de grande porte. 2005. 129f. Dissertação (Mestrado)- Escola de Engenharia de São Carlos, Universidade de São Paulo, São Carlos. 2005.

FUJIMOTO, G. S. Estudio Técnico económico para la instalación de un criadero de caracoles comestibles terrestres. 2006. 84f. Trabalho de conclução de curso (Ingeniero Indsutrial)- Facultad de Ingenieria Industrial, Universidad Nacional Mayor de San Marcos, Lima, 2006.

GALlOTI, L. A. Porque la Helicicultura?Asociación de Helicicultores de Argentina. Disponível em: <http://www.una-gauchada.com/agro/por-qu-helicicultura-359.html>. Argentina 2014. Acesso em: 15 de dezembro de 2014.

GOMEZ, S. M. A; BAUTISTA, G. A. E. Creación y puesta em marcha de uma empresa de cultivo de caracoles para laobtención de baba de caracol. 2010. Monografia (Graduação em Ingenieria Industrial)- Facultad de IngenieriaFisico-Mecanica, Universidad Industrial de Santander, Bucaramanga, 2010.

HABERMAS, J. The theory of communicative action - life world and system: a critique of functionalistreas on. Boston: BeaconPress, 1987.

HINOJOSA, A. C. P. Plan de negocio: Cría de caracoles en cautiverio. 2012. $107 \mathrm{f}$.

Trabalho de conclução de curso (Licenciatura em Administración)- Facultad de Ciencias Sociales y Administrativas, Universidad del Aconcagua, Santiago, 2012.

HUGHES, E. C. The ecological aspecto f institution.American Sociological Review, v.1, n.2, p.180-189. 1936.

The study of institutions.Social forces, v.20, n.3, p.307-310. 1942.

IGUA, M. A; SANDOVAL, R. A. A. Estúdio de mercadopara la exportación de caracol "Helix Aspersa" aEspaña.Monografia (Administração de

EmpresasAgropecuarias).2008.Facultad de Aministración de Empresas Agropecuarias, Universidad de la Salle, Bogota, 2008.

INSTITUTO COLOMBIANO AGROPECUARIO (ICA). ICA en el comercio de peces, moluscos, crustáceos vivos y sus productos.2009. Disponível em:

$<$ http://www.ica.gov.co/Noticias/Pesca-y-Acuicultura/2009/ICA-en-el-comercio-de-peces,moluscos,-crustaceos-.aspx>. Acesso em julho de 2015.

Normatividad. 2012. Disponível em

$\langle$ http://www.ica.gov.co/Normatividad/Normas-Ica/Resoluciones/2010.aspx?page=5 $>$. Acesso em agosto de 2015.

INSTITUTO COLOMBIANO AGROPECUARIO. Ley 1011 de 2006. Disponível em <http://www.ica.gov.co/getattachment/23b31418-469a-4d32-82a9-

fb3fff679454/2006L1011.aspx >. Acesso em agosto de 2015.

Resolución 1464 de 2010. Disponível em

<http://www.ica.gov.co/Normatividad/Normas-Ica/Resoluciones/2010.aspx?page=5>. Acesso em agosto de 2015.

JIMENEZ, R. P. D. Manejo controlado de la temperatura y humedad em caracoles de tierra de la espécie Helix aspersa em el município de Fusagasuga (Cundinamarca). 2007. 67f. Trabalho de conclução de curso (Zootecnista)- Facultad de Zootecnia, Universidad de la Salle, Bogota. 2007 
LAGOS, M. B. B. Evaluación técnica y económica de una crianza extensiva de caracoles (Hellix aspersa). 2004. 63f. Trabalho de conclução de curso (IngenieroAgronomo)- Facultad de Agronomia e Ingenieriaforestal, Departamento de CienciasAnimales, PontificiaUniversidadCatolica de Chile, Santiago, 2004.

LAPASSADE, G; LOUREAU, R. Chaves da Sociologia. 1972. RJ: Civilização Brasileira. 1972.

Grupos, organizações e instituições. 1985. Rio de Janeiro: Francisco Alves, 1985.

LÓPEZ, L. C. Redes organizacionales en el ámbito de la intervencíon social. Intervención Psicosocial, Madrid, v.12, n.3, p.269-282. 2004

MARTÍNEZ, M. L; BALLESTER, L. A. Cómo hacer cría de caracoles. Buenos Aires: Grulla, 2003. 60p.

MELUCCI, A. Challenging Codes. Collective Action in the Information Age. 1996. Cambridge University Press, Cambridge.

MINISTERIO DO MEIO AMBIENTE. Ley 99 de 1993. Disponível em $<$ https://www.minambiente.gov.co/index.php/ministerio/objetivos-y-funciones. Acesso em agosto de 2015.

Ley 165 de 1995. Disponível em

<https://www.minambiente.gov.co/images/BosquesBiodiversidadyServiciosEcosistemicos/pd f/Recursos_Gen\%C3\%A9ticos_Ley_165_de_1994.pdf>. Acesso em agosto de 2015.

MONJE, O. G; GUTIERREZ, A. Centro de Acopio, unaestrategia para competir enel mercado francéscon carne de caracol. 2009. 97f. Trabalho de conclução de curso (Administrador de Empresas)- facultad de Ciencias Econômicas y Administrativas, PontificiaUniversidadJaveriana, Bogotá, 2007.

MOTTA, F. P. Controle social nas organizações. Revista de Administração de Empresas, v. 19, n. 3, p. 11-25, 1979.

NIÑO, J. C; TORRES, J. A. L. Comercialización de caracoles terrestres comestibles em pro de lacreación de uma empresa exportadora. 2013. 45f.Dissertação (Administração de Empresas)- Facultad de CienciasEconomicas y Administrativas,

PontificiaUniversidadJaveriana, Bogotá, 2013.

NORTH, D. C. Instituciones, cambio institucional y desempeño económico. 1998. Lecturas de economía, Medellin, n.49, p.214-220.

OLIVIERI, L. A importância histórico-social das redes. Manual de Redes Sociais e Internet do Centro de Direitos Humanos, v. 2. Rio de Janeiro: CDH, 2003. Disponível em: <www.cdh.org.br>. Acesso: novembro de 2014.

OLSON, M. Auge y decadencia de las naciones: La lógica de la acción colectiva. 1985. Barcelona

OSPINA, L. A. M; MORENO, D. M. M. Factibilidad para el desarrollo de um proyecto piloto para la cría de caracol terrestre comestible. 2007. 50f. Trabalho de conclução de curso (Gerencia de Proyectos emIngenieria)- División de formación avanzada, Universidad de la Salle, Bogotá, 2007.

PECI, A. A nova teoría institucional em estudos organizacionais: Uma abordagem critica. Cadernos EBAPE, Rio de Janeiro, v.4, n.1, p.2-12. 2006. 
PEREIRA, D. D; DE FARIA. S.N.S; LOPES. P. R. A rede de empresas: o caso da associação das indústrias de laticínios da região campo das vertentes. In: Congresso Sociedade Brasileira de Economia, Administração e Sociologia Rural, 52., 2014. Goiânia Anais... Goiânia: SOBER, 2014.

PEREYRA, L. R. et. al. La helicicultura. 2003. INVENIO,Rosario, v. 6, n. 11, p. 127-134, nov. 2003.

PERUCCI, Robert; POTTER, H, R. 1989.Networks of power.Organizational actors at the national corporate, and community levels.EstadosUnidos: Aldine de Gruyter. 1989.

PINZÓN, C. P; BARACALDO, L.A; ARDILA, N. T. Plan de Negociosparaexportación de carne de caracoldesde Colombia.2014. 101F. Monografia (Especialista em Finanzas y Negocios Internacionales)- Universidad de la Sabana, Bogotá, 2014.

POWELL, W.DIMAGIO, P. Jr (org). 2001. El Nuevo Institucionalismo en el Análisis Organizacional. México: Fondo de Cultura Económica.

PROAÑO, M. L; LEMA, M. P; VALVERDE, R. R. Diseño de um modelo de negocio de exportación, de umproduto no tradicional, el HelixAspersaMuller. 2006. 148f.

Dissertação (Magíster em Administración de Empresas)- Centro de Negocios, Pontificia Universidad Católica del Perú, Surco, 2006.

QUintero, J. F. M; MOLINA, P. C. J; MARUlandA, S. P. B. Caracoleta S. A. Protocolo Plan de Negocios.2007. 126f. Escuela de administración, Institución Universitaria CEIPA, Antioquia, 2007.

QUINTERO, S. Y. B; GALINDO, A. B. Plan para el desarrollo de um proceso de helicicultura em Gacheta Cundinamarca, com destino a la exportación. 2007. 95f.

Trabalho de conclução de curso (Administração de Empresas)- Facultad de Administración de Empresas, Universidad de la Salle, Bogotá. 2007

RAMIREZ, A. S. Fundamentos de administración. 2014. Bogotá: Ecoe Ediciones.

RODRIGUES, M. P. Manual Prático para a criação de caracóis (escargots). São Paulo: ÍCONE, 1991.(Coleção Brasil Agrícola, 2). 120p.

RODRÍGUEZ, M. D. Diagnóstico organizacional. 1999. $3^{\text {a }}$ ed. Editorial Alfaomega.

RODRIGUEZ, M. L.et. al. Encadenamiento de la productividad helicícolaem el departamento de Cundinamarca (Colombia).Revista Electronica de Gerencia Empresarial, COEPTUM, URBE, Maracaibo, v. 2, no. 2, p. 168-197. 2011.

SALINAS, M. R. E. Helicicultura em Rio Bueno. 2006. 132f. Monografia (Ingeniero Comercial)- Facultad de Ciencias Económicas y Administrativas, Universidad Austral de Chile, Valdivia, 2006.

SASTRE, R.F. La cría de caracol en la Argentina: una alternativa de agronegocios. 2006. 120 f. Dissertação (Magíster em agronegócios y alimentos)- Programa de Agronegócios y Alimentos, Universidad de Buenos Aires, Buenos Aires. 2006.

SELZNICK, P. A Liderança na Administração: uma interpretação sociológica. RJ: FGV. 1972. TVA and the grass roots.New York: Harper \&Row. 1949.

$\overline{\text { Harvard) }}$ Gerentes e lideres são diferentes? São Paulo: Nova cultural. 1996 (Coleção 
SIERRA, J. A. B. Analisis Organizacional de la dinámica interna de las empresas construtoras destacadas del eje cafetero. 2009. 155f. Dissertação (Magister enAdministración), Universidad Nacional de Colombia, Manizales, 2009.

SILVEIRA, L.F; GARCIA, F.C. Mudanças Organizacionais e Impacto Cultural: Um estudo de caso de aquisição. Revista Alcance-eletronica. vol 17. No. 3. 2010.

SULBRANDT, J; LIRA, R; IBARRA, A. Redes interorganizacionales en la administración pública. 2001. Caracas: Revista del CLAD Reforma y Democracia. No. 21. 2001

VIEIRA, M. I. Escargots: criação doméstica e comercial. 2. Ed. São Paulo: NOBEL S.A, 1984.90P.

ZAMBRANO, J. Dados enviados via e-mail. Bogotá, abril. 2015. 


\section{APÊNDICE A- ROTEIRO DE AFIRMATIVAS}

Bogotá Octubre de 2015

Cordial saludo

Mi nombre es LEYDY EVONNE LOPEZ PALECHOR, actualmente estudiante de Posgrado (Maestría) en Agronegócios de la Universidad de Brasilia - Brasil. Estoy desarrollando mi trabajo de investigación en el tema de la Helicicultura en Colombia. Presento el siguiente cuestionario de preguntas con el ánimo de recolectar datos de gran importancia para análisis de resultados y llegar a obtener buenas conclusiones. Me gustaría saber si me puedes colaborar con esta encuesta con preguntas sencillas y fáciles de responder.

De antemano muchas gracias por la ayuda prestada.

Datos personales y de la organización

Nombre:

Edad:

Sexo: F M

Nombre de la organización:

Tipo de organización:

Cargo actual:

Año de creada la empresa:

Activa Inactiva

Las siguientes afirmaciones van relacionadas al tema de la helicicultura, separados por temas. Por favor, puedes calificar de 1 a 5 cada ítem presentado, donde 1 (totalmente en desacuerdo) y 5 (totalmente de acuerdo), considerando dos períodos en la historia de la actividad en Colombia (2003 y 2013). Marque con una X a opción que le parece más adecuada para cada periodo de tiempo.

\section{SOBRE LA LEGISLACIÓN, COMERCIO Y PRODUCCIÓN ASOCIADA}

1. La ley 99, de diciembre de 1993, que trata de la gestión y conservación del medio ambiente y los recursos naturales renovables afectó la producción de caracol en Colombia

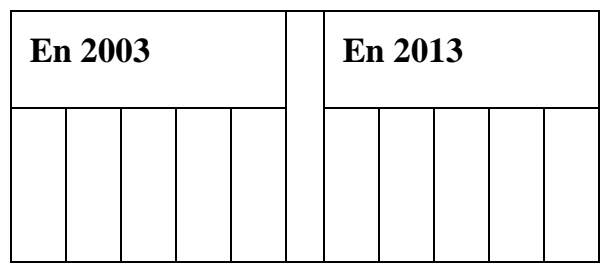

2. El convenio de las naciones decretado en la ley 165 de 1994 que protege la diversidad biológica influenció en la producción de caracol en Colombia

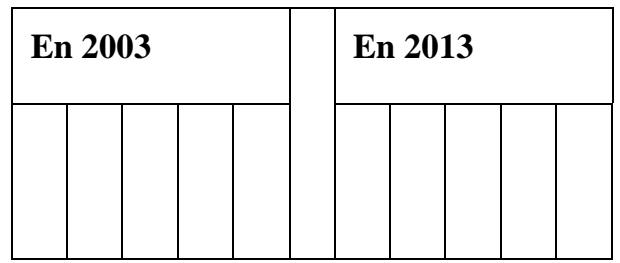

3. Con la implementación de la ley 1011 de 2006 que reglamenta la actividad de la helicicultura se vieron afectados los cultivos de caracol en Colombia




4. Mediante la ley anteriormente descrita se decretaron la obtención de licencias ambientales. Este proceso afectó la producción y comercialización de esta especie en Colombia

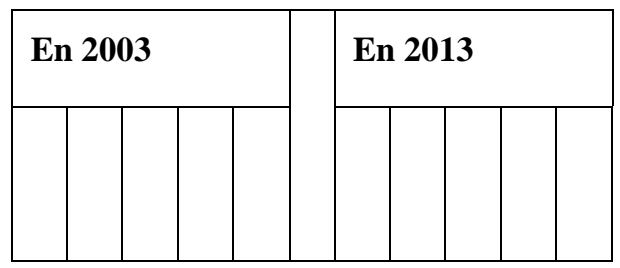

5. Las norma técnicas de calidad afectaron los predios de los productores de caracol en Colombia

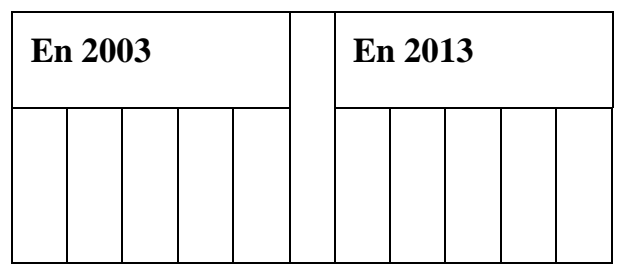

6. Con la reglamentación que tuvo esta actividad, disminuyo la exportación e importación de caracol en Colombia

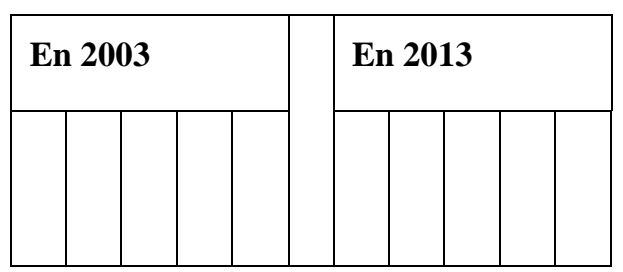

7. Los procesos y procedimientos de exportación son influencia para las personas generar producción de caracol

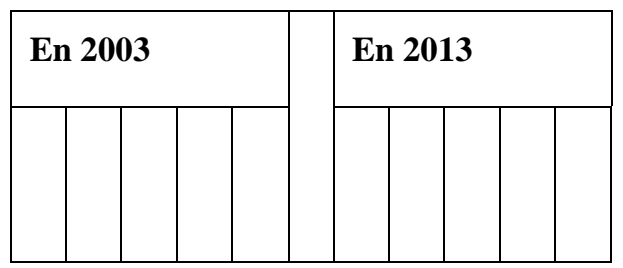

8. Los requerimientos de los países importadores por obtener productos de excelente calidad influyen en el proceso de producción y comercialización de caracol en Colombia



9. La tecnología utilizada para la producción y manutención de la cría de caracol ha influenciado en los procesos de crecimiento de esta actividad agrícola

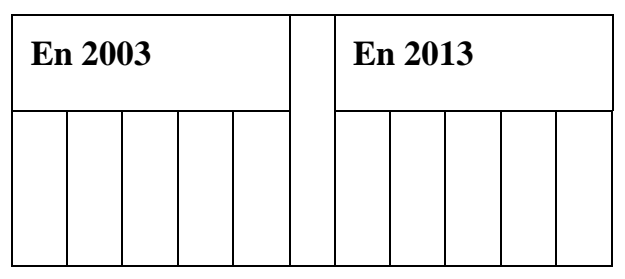

10. Los costos para nueva tecnología influyen en los análisis de inversión para la producción de caracol en Colombia

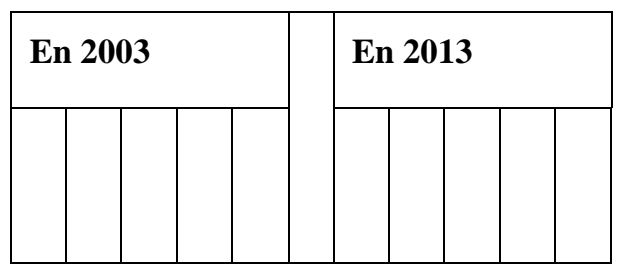

11. Las legislaciones sobre la helicicultura incentivo la formación de asociaciones, cooperativas para ayudar al desarrollo de esta actividad

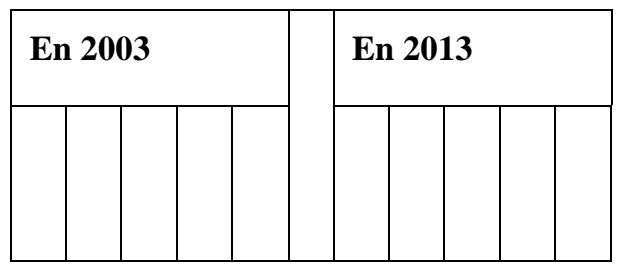


12. La falta de asociaciones consolidadas que apoyen el desarrollo de esta actividad es un factor determinante de la producción de caracol en Colombia



13. Para incentivar la producción de caracol se cuentan con líneas de crédito, préstamos a baja tasa de interés, para siembra y mantenimiento de la producción

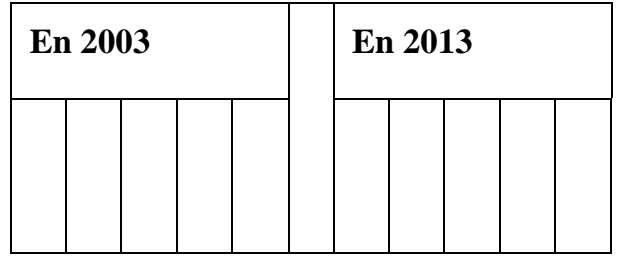

14. El transporte (terrestre, aéreo, marítimo) de los productos requieren de protocolos para poder exportar, estos protocolos intervienen en la producción de caracol



15. Hacer alianzas estratégicas con otras empresas del sector ha debilitado la producción de caracol en Colombia

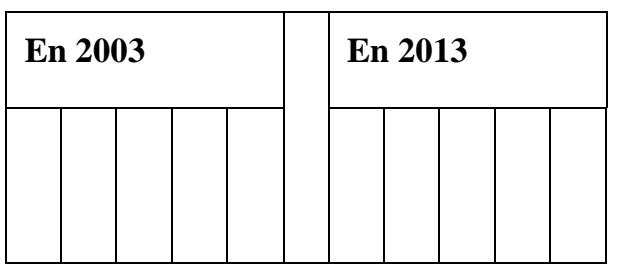

\section{SOBRE LA ESTRUCTURA, GESTIÓN Y ASISTENCIA TECNICA}

16. Para toda actividad agrícola es importante tener asistencia técnica que permita obtener productos de excelente calidad, la helicicultura posee estas asistencias técnicas a los predios productores

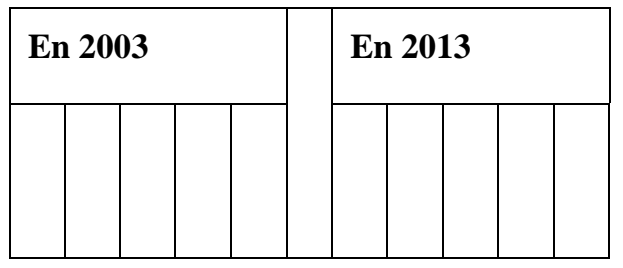

17. Para obtener un producto de buena calidad es importante la asistencia técnica por parte de las instituciones encargadas, este proceso favorece el desarrollo de la helicicultura en Colombia

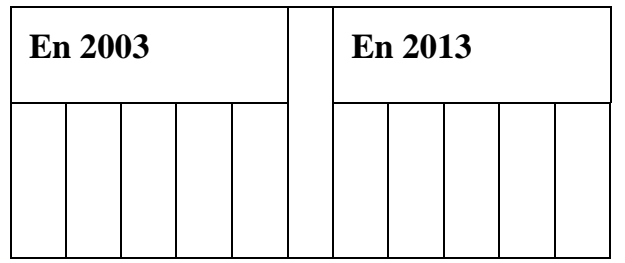

18. Para el desarrollo de esta actividad se cuenta con personal capacitado para apoyar a los helicicultores

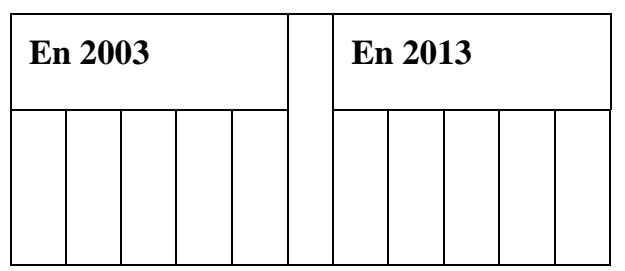

19. Este personal cuenta constantemente con capacitaciones que permitan desarrollar un trabajo de calidad

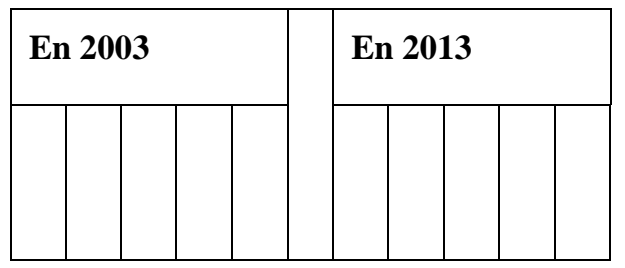


20. Los protocolos de las visitas técnicas (tiempo de la visita, tiempo entre una visita y otra) influye en el desarrollo de los predios productores de caracol

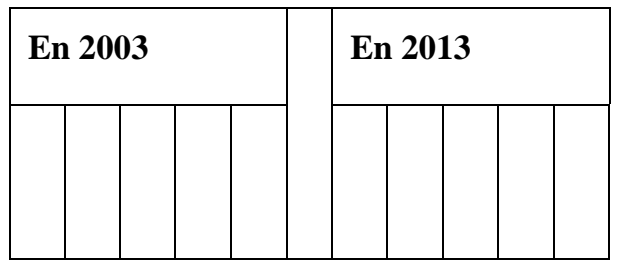

21. Las capacitaciones a los productores por parte de las instituciones encargadas influyen en el desarrollo de la actividad helicícola en Colombia

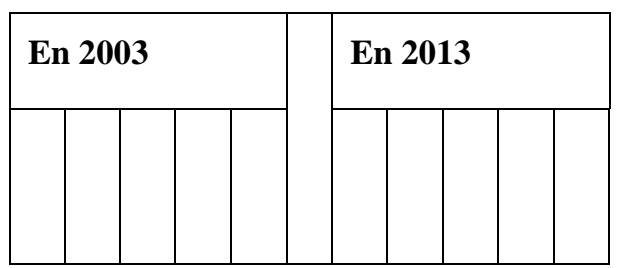

22. Estas capacitaciones permiten obtener nuevos conocimientos de técnicas e insumos requeridos, la adquisición de estos insumos es un factor determinante en el desarrollo de esta actividad

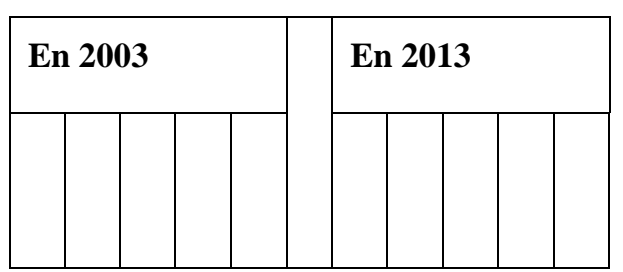

23. La cantidad de proveedores y la calidad de los insumos son un determinante para la producción de caracol

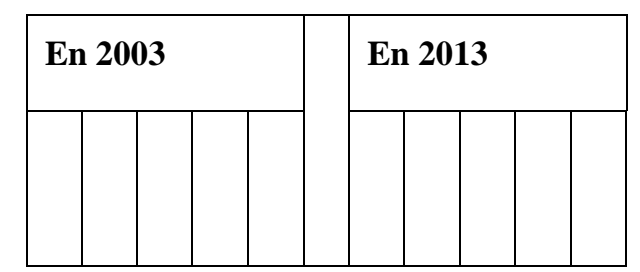

24. Los costos de los insumos influencian en el desarrollo de la helicicultura

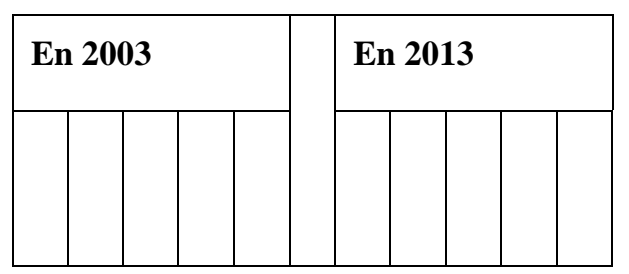

25. Las vías de acceso para transporte de productos son factores que determinan la producción de caracol en Colombia

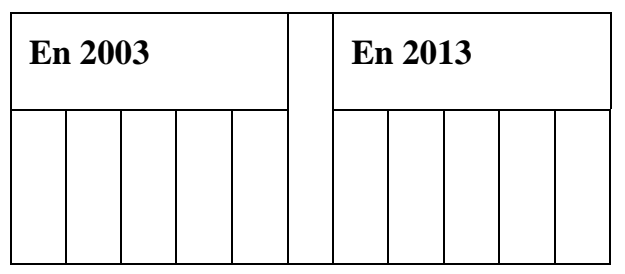

26. El clima, los suelos, temperatura son factores determinantes de la producción de esta especie en Colombia

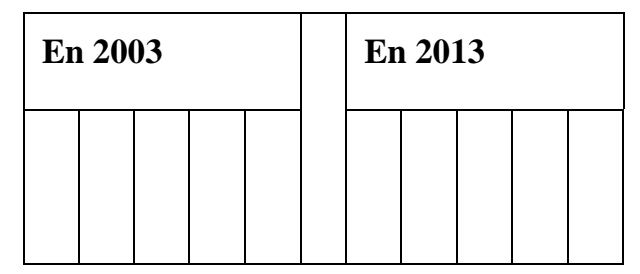

27. La mano de obra calificada permite obtener óptimos resultados. En Colombia se cuanta con este tipo de mano de obra capacitada para desarrollar esta actividad

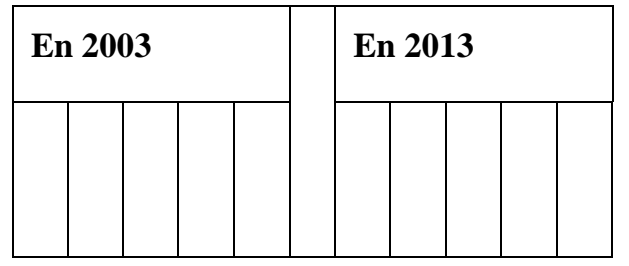


28. Los procesos de investigación e innovación influencian en el desarrollo de esta actividad en Colombia

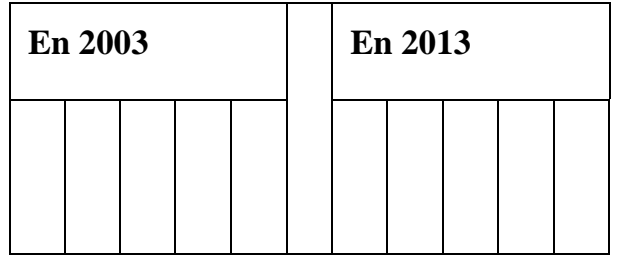

29. Los conflictos sociales, culturales, políticos influyen en la decisión de invertir en esta actividad

\section{RED DE HELICICULTORES (ASOCIADOS)}

30. Una red consolidada de helicicultores contribuye al crecimiento de la producción de caracol en Colombia
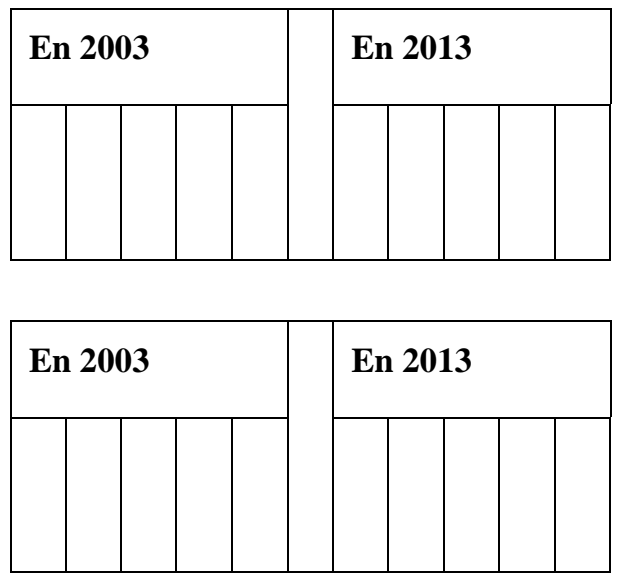

31. La estructura organizacional de esta red influye en el proceso de producción de caracol en Colombia

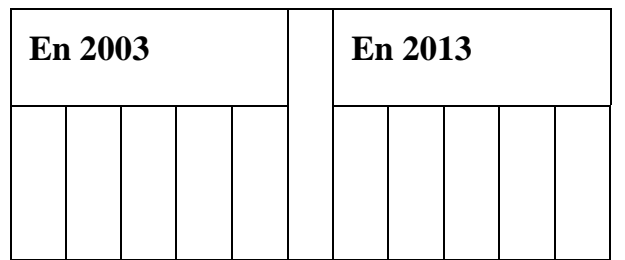

32. Los procesos y procedimientos adoptados por esta red contribuirían al desarrollo de la actividad

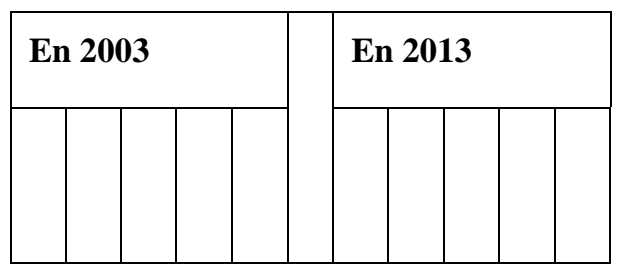

33. La relación de esta red con las instituciones que rigen esta actividad influencia en el desarrollo de la actividad



34. La relación y participación de los asociados en la toma de decisiones dentro de las asociaciones influye en el desarrollo de la helicicultura en Colombia

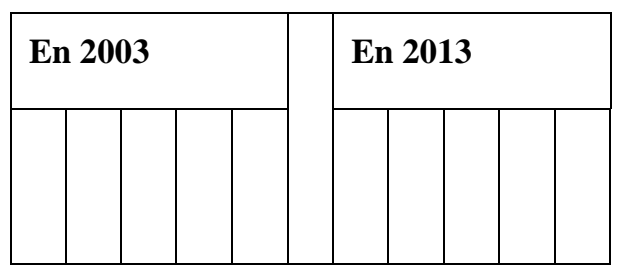




\section{UNIDAD PRODUCTIVA}

35. La extensión de tierra de los productores colombianos son adecuadas para la producción de caracol para exportar

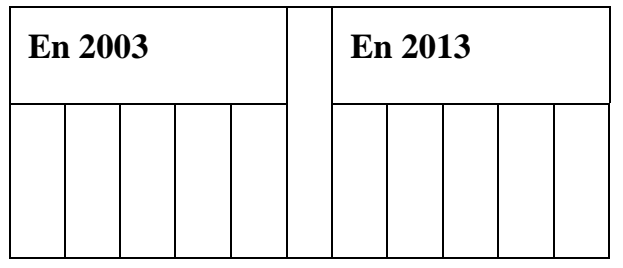

36. La calidad de estas tierras influencia en el cultivo de caracol en Colombia

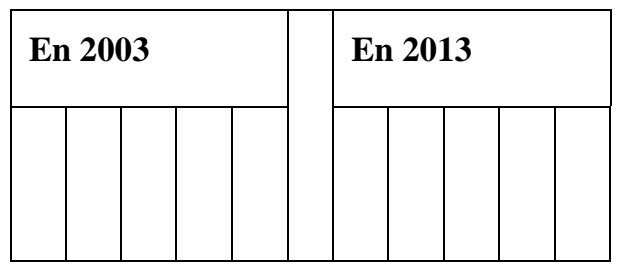

37. La capacidad de los recursos (financieros, patrimoniales) que poseen los productores influye en la producción de caracol para poder exportar

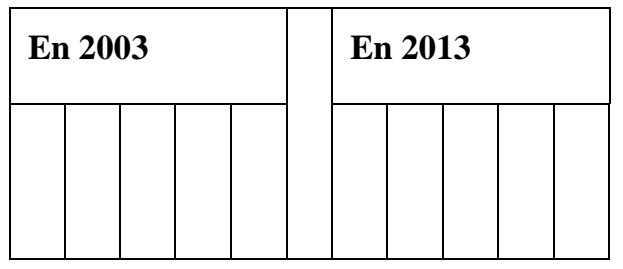

38. El tipo de mano de obra de su escogencia es el adecuado para el cultivo de caracol

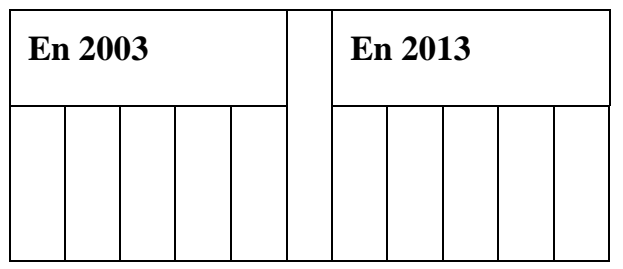

39. Se ejecuta la adecuada capacitación para mejorar la calidad del producto para el personal de labores helicícolas



40. La venta de la producción a terceras personas, no directamente con las asociaciones influencia en el proceso de desarrollo de esta actividad

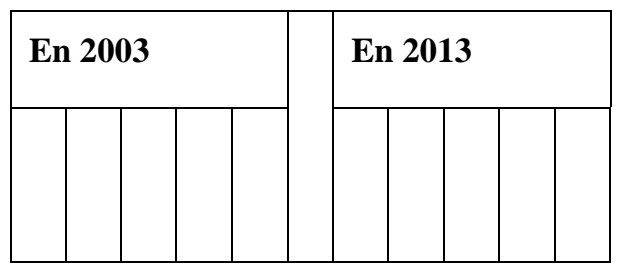

Muchas gracias por su valiosa colaboración en este proceso de investigación. 


\section{ANEXOS}

\section{ANEXO 1. Arquivos consultados na ANLA}

\begin{tabular}{|c|c|c|c|}
\hline LAM 3790 & $\begin{array}{l}\text { Licencia } \\
\text { ambiental }\end{array}$ & $\begin{array}{l}\text { "Introducción de Caracoles de Tierra Parentales } \\
\text { Foráneos de la Variedad Hélix aspersa, y su } \\
\text { establecimiento en un Zoocriadero Cerrado con fines } \\
\text { comerciales, bajo cl modelo Helix del Sur a cielo } \\
\text { abierto con ciclo biológico completo, en } \\
\text { confinamiento estricto y en condiciones } 100 \% \\
\text { naturales, ubicado en la finca El Porvenir, de la } \\
\text { vereda Pascata del municipio de Turmeque, } \\
\text { departamento de Boyacá (Colombia) }\end{array}$ & Seguimiento \\
\hline L.AM 3804 & $4 \begin{array}{l}\text { 1.icencia } \\
\text { ambiental }\end{array}$ & $\begin{array}{l}\text { "Introducción de parentales y el establecimiento de } \\
\text { un zoocriadero de caracoles terrestres de la especie } \\
\text { Hélix aspersa" a ubicarse en la finca Monterrey, } \\
\text { vereda El Tablazo, municipio de Rionegro, en el } \\
\text { departamento de Antioquia }\end{array}$ & Remitido \\
\hline 1. AMB:36 & $6 \begin{array}{l}\text { Licencia } \\
\text { ambiental }\end{array}$ & $\begin{array}{l}\text { Cria de caracoles Helizx Aspersa en el municipio de } \\
\text { El Salao - Tolima }\end{array}$ & Remitido \\
\hline LAM3227 & $\begin{array}{l}\text { Liccncia } \\
\text { a mbiental }\end{array}$ & $\begin{array}{l}\text { Importación y cria de caracoles terrestres de la } \\
\text { especie Helix Aspersa }\end{array}$ & Evaluación \\
\hline 1.AM32: & $\begin{array}{l}\text { Licencia } \\
\text { ambiental }\end{array}$ & $\begin{array}{l}\text { Importación y cria de caracoles Terrestres de la } \\
\text { especie Helix Aspersa }\end{array}$ & Archivado \\
\hline LAM $32=$ & $\begin{array}{l}\text { Licencia } \\
\text { ambicntal }\end{array}$ & $\begin{array}{l}\text { Introducció y exportación de caracoles de la cspecic } \\
\text { helix aspersa }\end{array}$ & Archivado \\
\hline$\underline{L A}$ & $\begin{array}{l}\text { Licencia } \\
\text { ambiental }\end{array}$ & $\begin{array}{l}\text { INTRODUCCION Y ESTABLECIMIENTO DE } \\
\text { CARACOLES TERRESTRES DE LA ESPECIE } \\
\text { HELIX ASPERSA DESDE PERU }\end{array}$ & Archivado \\
\hline$\underline{\mathrm{LA}}$ & $\begin{array}{l}\text { Licencia } \\
\text { ambiental }\end{array}$ & $\begin{array}{l}\text { INTRODUCCION AL PAIS DE } 1000 \text { CARACOLES } \\
\text { (HELIX ASPERSA) REPRODUCTORES Y } \\
\text { ESTABLECIMIENTO DE UNZOOCRIADERO }\end{array}$ & Archivado \\
\hline & $\begin{array}{l}\text { 1.icencia } \\
\text { ambiental }\end{array}$ & $\begin{array}{l}\text { Intreducción de } 1,375 \text { Caracoles terrestres de la } \\
\text { especie Helix Aspersa, de la empresa FYE } \\
\text { Agroexport } S A C \text {, de Lima Peru, y el establecimiento } \\
\text { de un zoocriadero en la finca Fangorn, vereda Ia } \\
\text { Playa del municipio de la Ceja en el departamento de } \\
\text { Antioquia }\end{array}$ & Remitido \\
\hline LAM4146 & $\begin{array}{l}\text { l.icencia } \\
\text { ambiental }\end{array}$ & $\begin{array}{l}\text { Introducción de } 2000 \text { Carácoles de la especie I Jelix } \\
\text { Aspersa, provenientes de Perú y establecimiento de } \\
\text { un zoo Triadero en la finca los Corrales, vereda }\end{array}$ & Evaluación \\
\hline
\end{tabular}




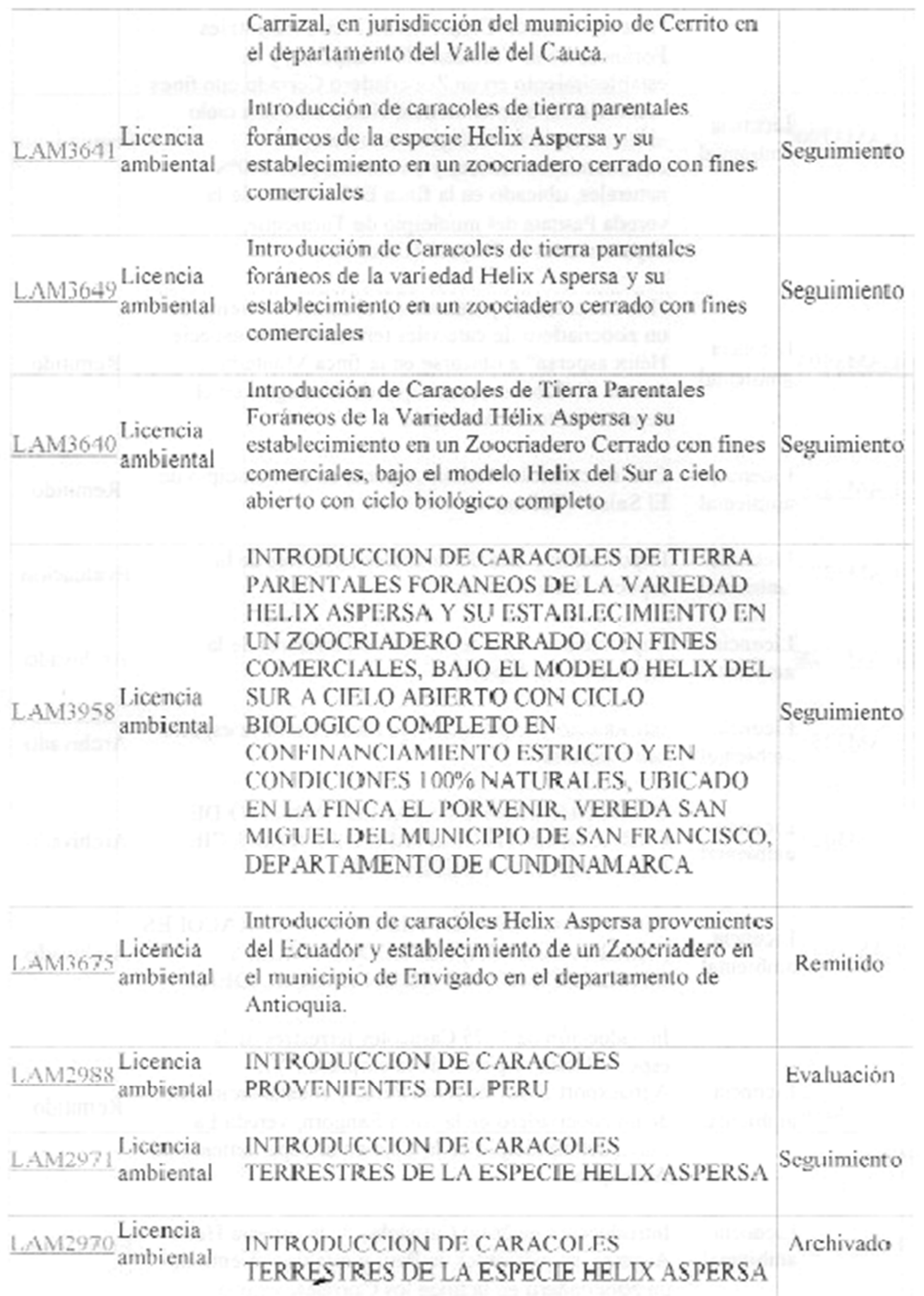




\begin{tabular}{|c|c|c|c|}
\hline & & DESDE PERU & \\
\hline LAM3019 & $\begin{array}{l}\text { Licencia } \\
\text { ambiental }\end{array}$ & $\begin{array}{l}\text { INTRODUCCION DE CARACOLES } \\
\text { TERRESTRES DE LA ESPECIE HELIX ASPERSA } \\
\text { DESDE PERU }\end{array}$ & Archivado \\
\hline LAM 308 & $\begin{array}{l}\text { Licencia } \\
\text { ambiental }\end{array}$ & $\begin{array}{l}\text { INTRODUCCION Y ESTABLECIMIENTO DE UN } \\
\text { ZOOCRIADERO DE CARACOLES HELIX } \\
\text { ASPERSA }\end{array}$ & Archivado \\
\hline 1.AM 3222 & $\begin{array}{l}\text { Licencia } \\
\text { ambiental }\end{array}$ & $\begin{array}{l}\text { Introducción y cria de caracoles de la especic Helix } \\
\text { Aspersa }\end{array}$ & Archivado \\
\hline LAM3223 & $\begin{array}{l}\text { Licencia } \\
\text { ambiental }\end{array}$ & $\begin{array}{l}\text { Introduccion y cria de caracoles de la especie Helix } \\
\text { Aspersa }\end{array}$ & Seguimiento \\
\hline L.AM4095 & $\begin{array}{l}\text { Licencia } \\
\text { ambiental }\end{array}$ & $\begin{array}{l}\text { Introducción y Cria de Caracoles terrestres de la } \\
\text { especie Helix Aspersa provenientes de Perí }\end{array}$ & Evaluación \\
\hline L.AMBO & $\begin{array}{l}\text { Licencia } \\
\text { ambiental }\end{array}$ & $\begin{array}{l}\text { LICENCIA AMBIENTAL PARA LA } \\
\text { IMPORTACION DE PARENTAL.FS DE } \\
\text { CARACOLES DE LA ESPECIE HELIX ASPERSA } \\
\text { (MULLER, 1786) }\end{array}$ & Seguimiento \\
\hline$\underline{\text { LAM } 3034}$ & $\begin{array}{l}\text { Licencia } \\
\text { ambiental }\end{array}$ & $\begin{array}{l}\text { LICENCIA AMBIENTAL PARA EL PROYECTO } \\
\text { DE: HELICICULTURA(CRIA O CULTIVO DE } \\
\text { CARACOIISS TERRESTRES) }\end{array}$ & Archivado \\
\hline$\underline{\operatorname{LAM} 3040}$ & $\begin{array}{l}\text { Licencia } \\
\text { ambientálál }\end{array}$ & $\begin{array}{l}\text { LICENCIA AMBIENTAL PARA LA } \\
\text { IMPLEMENTACION DE UN CRIADERO DE } \\
\text { CARACOIIES DE: TIIRRA DE LA ESPECIE } \\
\text { HELIX ASPERSA }\end{array}$ & Archivado \\
\hline$\underline{\mathrm{LAM}} 3111$ & $\begin{array}{l}\text { Licencia } \\
\text { ambiental }\end{array}$ & $\begin{array}{l}\text { LICENCIA AMBIENTAL PARA LA } \\
\text { IMI'ORTACION DE CARACOLES DE LA } \\
\text { TSPECIE IIELIX ASPERSA }\end{array}$ & Archivado \\
\hline LAM3110 & $\begin{array}{l}\text { Licencia } \\
\text { ambiental }\end{array}$ & $\begin{array}{l}\text { I.ICFNCIA AMBIENTAI. PARA IA } \\
\text { IMIORTACION Y CRIA DE CARACOLES DE LA } \\
\text { ESPECIE HEIIX ASPERSA }\end{array}$ & Archivado \\
\hline I.AM 13108 & $\begin{array}{l}\text { Licencia } \\
\text { ambiental }\end{array}$ & $\begin{array}{l}\text { I.ICTENCIA AMBIENTAI. PARA I.A } \\
\text { IMPORTACION Y CRIA DE CARACOLES DE LA } \\
\text { ESIPCIE HELIX ASPERSA }\end{array}$ & Archivado \\
\hline
\end{tabular}




\begin{tabular}{|c|c|c|c|}
\hline LAM3 109 & $\begin{array}{l}\text { Licencia } \\
\text { ambiental }\end{array}$ & $\begin{array}{l}\text { LICENCIA AMBIENTAL PARA LA } \\
\text { IMPORTACION Y CRIA DF: CARACOLES DE LA } \\
\text { ESPECIE HELIX ASPERSA }\end{array}$ & Archivado \\
\hline LAM 3113 & $\begin{array}{l}\text { Licencia } \\
\text { ambiental }\end{array}$ & $\begin{array}{l}\text { LICENCIA AMBIENTAL PARA LA } \\
\text { IMPORTACION Y CRIA DE CARACOLES DE LA } \\
\text { ESPECIE HELIX ASPERSA }\end{array}$ & Seguimiento \\
\hline LAM 36 & $\begin{array}{l}\text { Licencia } \\
\text { ambiental }\end{array}$ & $\begin{array}{l}\text { Licencia Ambiental para la introducción al pais de } \\
\text { Caracoles de la especie Helix } \Lambda \text { spersa, y el } \\
\text { establecimicnto de un zoocriadero en la vereda } \\
\text { Páramo Bajo del municipio de Tausa en el } \\
\text { departamento de Cundinamarca. }\end{array}$ & Seguimiento \\
\hline LAM30 & $\begin{array}{l}\text { Iicencia } \\
\text { ambiental }\end{array}$ & $\begin{array}{l}\text { LICENCIA AMBIENTAL PARA LA } \\
\text { INTRODUCCION DE NUEVOS PARENTALES } \\
\text { GENETICAMENTE MEJORADOS PARA LA } \\
\text { CRIA Y COMERCIALIZACION DE CARACOLES } \\
\text { IIELIX ASPERSA. }\end{array}$ & Seguimiento \\
\hline LAM3174 & $\begin{array}{l}\text { Licencia } \\
\text { ambiental }\end{array}$ & $\begin{array}{l}\text { LICENCIA AMBIENTAL PARA LA } \\
\text { INTRUDUCCION Y CRIA DE CARACOI.ES } \\
\text { TERRESTRES DE LA ESPECIE HELIX ASPERSA }\end{array}$ & Remitido \\
\hline $\mathrm{LAM} 3 \mathrm{O}_{2}$ & $\begin{array}{l}\text { Licencia } \\
\text { ambiental }\end{array}$ & $\begin{array}{l}\text { LICENCIA AMBIENTAL PARA UN } \\
\text { ZOOCRIADERO DE CARACOLIES HEI.IX } \\
\text { ASPERSA }\end{array}$ & Seguimiento \\
\hline & $\begin{array}{l}\text { I.icencia } \\
\text { ambiental }\end{array}$ & $\begin{array}{l}\text { LICENCIA PARA EL ESTABLECIMIENTO DE } \\
\text { ZOOCRIADERO FASE EXPERIMENTAL DE } \\
\text { CARACOLES }\end{array}$ & Archivado \\
\hline I.AM 1.311 & $\begin{array}{l}\text { Licencia } \\
\text { ambiental }\end{array}$ & $\begin{array}{l}\text { LICENICA AMBIENTAL PARA I.A } \\
\text { IMPORTACION Y CRIA DE CARACOLES DE LA } \\
\text { ESPFCIE HELIX ASPERSA }\end{array}$ & Archivado \\
\hline$\underline{\mathrm{LAM}} 29$ & $\begin{array}{l}\text { Licencia } \\
\text { ambiental }\end{array}$ & $\begin{array}{l}\text { PROYECTO DE HELIOCULTURA CRIA DF: } \\
\text { CARACOLES TERRESTRES }\end{array}$ & Archivado \\
\hline LA & $\begin{array}{l}\text { Licencia } \\
\text { ambiental }\end{array}$ & $\begin{array}{l}\text { 7OOCRIADERO DE CARACOLES DE LA } \\
\text { ESPECIE HELIX ASPERSA ACULUMO } \\
\text { ESCARGOT CHARGRINE }\end{array}$ & Archivado \\
\hline ND) $A 00$ & $\begin{array}{l}\text { Necesidad } \\
\text { diagnóstico } \\
\text { ambiental }\end{array}$ & $\begin{array}{l}\text { Introducción de Caracoles de Tierra Parentales } \\
\text { Foráneos de la Variedad Hélix aspersa, y su } \\
\text { establectmiento en un Zoocriadero Cerrado con lines }\end{array}$ & Evaluación \\
\hline
\end{tabular}


de comerciales, bajo el modelo Helix del Sur a cielo

alternativas abierto con ciclo biológico completo, en

confinamiento estricto y en condiciones $100 \%$

naturales", ubicado en la linca El Porvenir, de la

vereda Pascata del municipio de Turmeque,

departamento de Boyacá (Colombia).

\begin{tabular}{|c|c|c|c|}
\hline $\mathrm{NDAOI} 40$ & $\begin{array}{l}\text { Necesidad } \\
\text { diagnóstico } \\
\text { ambiental } \\
\text { de } \\
\text { alternativas }\end{array}$ & $\begin{array}{l}\text { CRIA DE CARACOIES TIERESTRE, FINCA EL } \\
\text { CARACOL }\end{array}$ & Evaluación \\
\hline VI) $\mathrm{A} 000 \mathrm{~s}$ & $\begin{array}{l}\text { Necesidad } \\
\text { diagnóstico } \\
\text { ambiental } \\
\text { de } \\
\text { alternativas }\end{array}$ & $\begin{array}{l}\text { Cria de caracoles terrestres de la especie Helix } \\
\text { aspersa", en el municipio de La Ccja, departamento } \\
\text { de Antioquia }\end{array}$ & Evaluación \\
\hline $\mathrm{NDA0043;}$ & $\begin{array}{l}\text { Necesidad } \\
\text { diagnóstico } \\
3 \text { ambicntal } \\
\text { de } \\
\text { alternativas }\end{array}$ & $\begin{array}{l}\text { Importación de parentales y desarrollo de zoocría de } \\
\text { caracoles de la especie Helix aspersa en el municipio } \\
\text { de Guateque, departamento de Boyacá }\end{array}$ & Evaluación \\
\hline NDA0199: & $\begin{array}{l}\text { Necesidad } \\
\text { diagnóstico } \\
\text { ambiental } \\
\text { de } \\
\text { alternativas }\end{array}$ & $\begin{array}{l}\text { importación de un pic de cria de } 72 \mathrm{Kgs} \text {. de caracoles } \\
\text { terrestres de la especie Hélix } A \text { spersa, equivalentes a } \\
7500 \text { reproductores provenientes de la empresa FYE } \\
\text { Agrocxport SAC, con marca registrada chef escargot } \\
\text { cavea - Phodama - Tonio veda tus aracos }\end{array}$ & $\begin{array}{l}\text { Evaluación } \\
20008\end{array}$ \\
\hline NDA014 & $\begin{array}{l}\text { Necesidad } \\
\text { diagnóstico } \\
\text { ambicntal } \\
\text { de } \\
\text { alternativas }\end{array}$ & $\begin{array}{l}\text { INTRODUCCION AL PAIS DE ( ARACOLIES DF: } \\
\text { I.A FSPECIT HELIX ASPERSA PROVENIENTES } \\
\text { DE P'ERU Y ZOOCRIA A DESARROLLARSE EN } \\
\text { LA VEREDA RIO ABAJO depts do Antroquos } \\
\text { O. lonegno }\end{array}$ & $\begin{array}{l}\text { Evaluación } \\
2008 \text {. }\end{array}$ \\
\hline NDA0046a & $\begin{array}{l}\text { Necesidad } \\
\text { diagnóstico } \\
\text { ambiental } \\
\text { de } \\
\text { alternativas }\end{array}$ & $\begin{array}{l}\text { Introduccion al pais de Caracoles I lelix Aspersa } \\
\text { Muller, provevientes del Ecuador y establecimiento } \\
\text { de un zoocriadero en la Finca la Marina, Vereda } \\
\text { Puente Pelácz, Municipio de Mesitas del Retiro, } \\
\text { Departamento de Antioquia. }\end{array}$ & Evaluación \\
\hline $0197^{\mathrm{N}}$ & $\begin{array}{l}\text { Necesidad } \\
\text { diagnóstico } \\
\text { ambiental }\end{array}$ & $\begin{array}{l}\text { Introducción de } 2000 \text { carácoles de la especie helix } \\
\text { aspersa, desde Peru }\end{array}$ & Evaluación \\
\hline
\end{tabular}




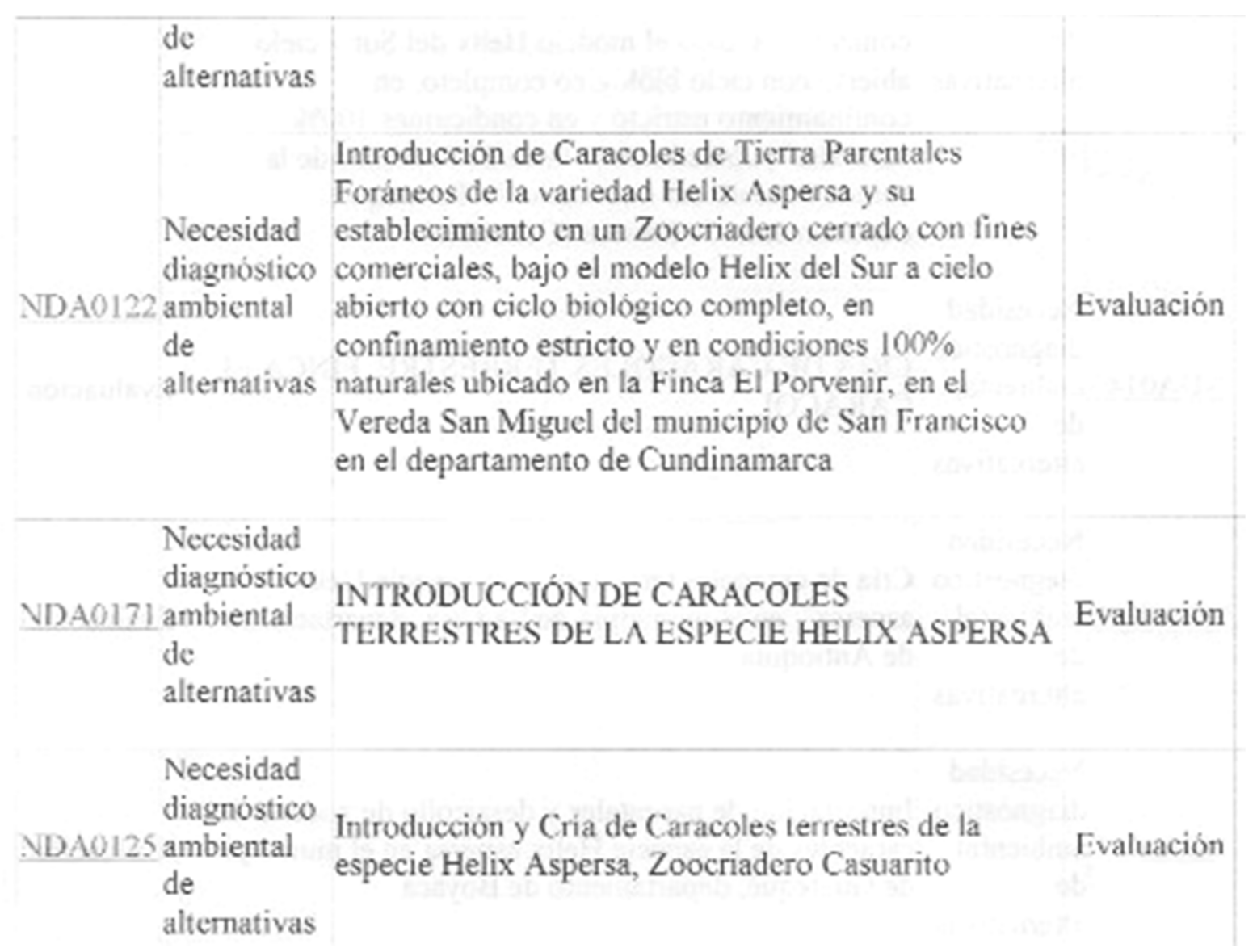




\section{ANEXO 2. Quadro de Excel de Exportações na Colômbia}

REPUBLICA DE COLOMBIA

DEPARTAMENTO ADMINISTRATIVO NACIONAL DE ESTADISTICA - DANE

GRUPO VENTAS DIRECTAS

DIRECCION DE DIFUSION, MERCADEO Y CULTURA ESTADISTICA

\section{EXPORTACIONES COLOMBIANAS POR PARTIDAS ARANCELARIAS Y PAISES DE DESTINO}

ENERO - DICIEMBRE2003

FUENTE: DANE (Cifras Definitivas)

\begin{tabular}{|c|c|c|c|c|c|}
\hline \multirow{2}{*}{$\begin{array}{l}\text { PARTIDA } \\
\text { ARANCELARIA }\end{array}$} & \multirow[b]{2}{*}{ DESCRIPCIÓN Y PAIS DESTINO } & \multicolumn{2}{|c|}{ K I L O G R A M O S } & \multicolumn{2}{|c|}{ V A L O R E SF.O.B. } \\
\hline & & BRUTOS & NETOS & $\begin{array}{l}\text { PESOS } \\
\text { COLOMBIANOS }\end{array}$ & DOLARES \\
\hline \multirow[t]{2}{*}{0307600000} & Caracoles, exceptolos de mar. & $88.554,00$ & $4.883,00$ & $\begin{array}{r}1.311 .0 \\
46.485,00 \\
1.311 .0\end{array}$ & $459.981,00$ \\
\hline & ESTADOS UNIDOS. & $88.554,00$ & $4.883,00$ & $46.485,00$ & $459.981,00$ \\
\hline
\end{tabular}

EXPORTACIONES COLOMBIANAS POR PARTIDAS ARANCELARIAS Y PAISES DE DESTINO

ENERO - DICIEMBRE2004

FUENTE: DANE (Cifras Definitivas)

$0307600000 \quad$ Caracoles, exceptolos de mar.

ESTADOS UNIDOS.

$\begin{array}{llrl} & & 1.053 .2 & \\ 67.253,06 & 3.030,37 & 64.143,02 & 391.446,50 \\ & & 1.053 .2 & \\ 67.253,06 & 3.030,37 & 64.143,02 & 391.446,50\end{array}$

EXPORTACIONES COLOMBIANAS POR PARTIDAS ARANCELARIAS Y PAISES DE DESTINO

ENERO - DICIEMBRE 2009

FUENTE: DANE - DIAN (Cifras Provisionales) : CALCULOS DANE

\begin{tabular}{|c|c|c|c|c|c|}
\hline \multirow{2}{*}{$\begin{array}{l}\text { PARTIDA } \\
\text { ARANCELARIA }\end{array}$} & \multirow[b]{2}{*}{ DESCRIPCIÓN Y PAIS DESTINO } & \multicolumn{2}{|c|}{ KILOGRAMOS } & \multicolumn{2}{|c|}{ V A L O R E SF.O.B. } \\
\hline & & BRUTOS & NETOS & $\begin{array}{l}\text { PESOS } \\
\text { COLOMBIANOS }\end{array}$ & DOLARES \\
\hline
\end{tabular}


4000

Antillas Holandesas

Estados Unidos

\begin{tabular}{rrrr} 
& $0.614,36$ & $00.208,33$ \\
& \multicolumn{3}{r}{1.252 .5} \\
$58.842,43$ & $7.188,00$ & $11.805,86$ & $559.173,12$ \\
& & 1.341 .4 & \\
$67.126,00$ & $3.426,36$ & $88.402,47$ & $644.652,14$
\end{tabular}

EXPORTACIONES COLOMBIANAS POR PARTIDAS ARANCELARIAS Y PAISES DE DESTINO

ENERO - DICIEMBRE 2010

FUENTE: DANE - DIAN (Cifras Provisionales) : CALCULOS DANE

0307994000

Caracoles de mar, congelados, secos, salados o en salmuera, aptos para la alimentación humana

Antillas Holandesas

Estados Unidos

EXPORTACIONES COLOMBIANAS POR PARTIDAS ARANCELARIAS Y PAISES DE DESTINO

ENERO - DICIEMBRE 2011

FUENTE: DANE - DIAN (Cifras Provisionales) : CALCULOS DANE

0307994000

Caracoles de mar, congelados, secos, salados o en salmuera, aptos para la alimentación humana.

Antillas Holandesas

Estados Unidos

EXPORTACIONES COLOMBIANAS POR PARTIDAS ARANCELARIAS Y PAISES DE DESTINO

ENERO - DICIEMBRE 2012

FUENTE: DANE - DIAN (Cifras Provisionales) : CALCULOS DANE

\begin{tabular}{|c|c|c|c|c|c|}
\hline \multirow{2}{*}{$\begin{array}{l}\text { PARTIDA } \\
\text { ARANCELARIA }\end{array}$} & \multirow[b]{2}{*}{ DESCRIPCIÓNPAIS DESTINO } & \multicolumn{2}{|c|}{ K I L O G R A M OS } & \multicolumn{2}{|c|}{ V A L O R E SF.O.B. } \\
\hline & & BRUTOS & NETOS & $\begin{array}{l}\text { PESOS } \\
\text { COLOMBIANOS }\end{array}$ & DOLARES \\
\hline \multirow[t]{2}{*}{0307600000} & Caracoles excepto de los de mar, vivos o frescos o refrigerados o congelados, secos, salados, ensalmuera o ahumados & 8,00 & 5,00 & $443.955,05$ & 246,96 \\
\hline & Canadá & 8,00 & 5,00 & $443.955,05$ & 246,96 \\
\hline
\end{tabular}

$\begin{array}{llrl} & & 178.917 & \\ 10.796,92 & 7.280,00 & .368,08 & 99.985,60 \\ & & 137.311 & \\ 8.360,00 & 5.280,00 & .922,88 & 76.665,60 \\ & & 41.605 . & \\ 2.436,92 & 2.000,00 & 445,20 & 23.320,00\end{array}$

$\begin{array}{llrl}93.541,67 & 9.041,99 & 1.605 .7 & \\ & & 71.056,35 & 849.454,00 \\ 31.616,54 & 9.992,00 & 496.494 & \\ & & .462,95 & 268.659,60 \\ 61.925,13 & 9.049,99 & 1.109 .2 & \\ & & 76.593,40 & 580.794,40\end{array}$


